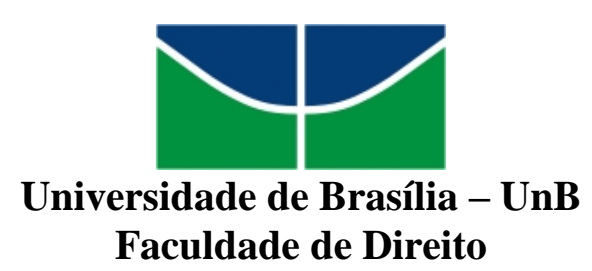

VICTOR SANTOS RUFINO

OS FUNDAMENTOS DA DELAÇÃO: ANÁLISE DO PROGRAMA DE LENIÊNCIA DO CADE À LUZ DA TEORIA DOS JOGOS

Brasília

2016 
UNIVERSIDADE DE BRASÍLIA

FACULDADE DE DIREITO

\section{OS FUNDAMENTOS DA DELAÇÃO: ANÁLISE DO PROGRAMA DE LENIÊNCIA DO CADE À LUZ DA TEORIA DOS JOGOS}

Autor: Victor Santos Rufino

Orientador: Prof. Dr. Márcio Nunes Iorio Aranha Oliveira

Dissertação apresentada como requisito parcial à obtenção do grau de Mestre, no Programa de Pós-Graduação da Faculdade de Direito da Universidade de Brasília, linha de pesquisa "Transformações da Ordem Social e Econômica e Regulação".

Brasília, de de 


\section{FOLHA DE APROVAÇÃO}

VICTOR SANTOS RUFINO

Os Fundamentos da Delação: Análise do Programa de Leniência do Cade à Luz da Teoria dos Jogos

Dissertação apresentada como requisito parcial à obtenção do grau de Mestre, no Programa de Pós-Graduação da Faculdade de Direito da Universidade de Brasília, linha de pesquisa "Transformações da Ordem Social e Econômica e Regulação".

Aprovada em: de de

\section{BANCA EXAMINADORA}

Prof. Dr. Márcio Nunes Iorio Aranha Oliveira (Orientador - Presidente)

Prof. Dra. Ana de Oliveira Frazão Vieira de Mello (Membro)

Prof. Dr. Marcos Paulo Veríssimo

(Membro)

Prof. Dr. Marcus Faro de Castro

(Suplente) 


\section{Agradecimentos}

Um empreendimento desta natureza, realizado por tão inexperiente autor, jamais poderia ser considerado obra sua. Ao contrário, é mero resultado da convivência com figuras extraordinárias, dos mais variados matizes, a quem deve ser prestado o devido tributo, por meio de palavras escritas e, sobretudo, no coração.

Em primeiro lugar, tenho uma dívida impagável com o Prof. Dr. Márcio Nunes Iorio Aranha Oliveira, que através do seu exemplo de scholar impecável, e de sua natureza organizada, paciente e generosa, proveio a seu inseguro orientando a energia necessária para transformar um plano de estudo frágil, desconexo e inconstante, em algo tangível, legível.

À equipe de procuradores que teve a má sorte de ser por mim liderada nesse período - a quem homenageio especialmente lembrando dos coordenadores Fernando Bastos, Rodrigo Belon, Fabio Sgueri, Gabriella Carvalho, Daniel Roque, Carolina Saboia e Daniela Borges - meu sincero agradecimento pela graciosidade com que muitas vezes conviveram com um chefe ausente e meu pedido de perdão contrito por tudo que tenha daí resultado. Aos meus antigos amigos de procuradoria, Gilvandro Araújo, Diogo Thomson e André Ramos, digo que, desde que os conheci, minha admiração me levou a almejar sempre ir tão longe quanto vocês, por isso também o mestrado.

Os meus colegas do Cade, Ricardo Medeiros, Deborah Caixeta, Lucas Freire, Amanda Linhares, Marcela Mattiuzzo, Ricardo Leite, Paulo Burnier, Luiza Kharmadayan (e sua equipe André Rothfeld, Fábio Lopes e Raíssa Guerreiro), que influenciaram diretamente este trabalho, representam à perfeição o magnífico corpo técnico dessa instituição, que, todo ele, me estimulou, ao longo dos anos, a buscar me superar na vida profissional e acadêmica. A Eduardo Frade, agradeço por ter me demonstrado, pelos seus feitos, que essa missão era possível, mesmo em circunstâncias mais difíceis que as por mim enfrentadas. A Vinicius de Carvalho, fica o reconhecimento pelas intermináveis conversas sobre todo tipo de tema, influência marcante e definitiva. Também agradeço a Carlos Ragazzo e Ana Frazão, pela orientação sempre carinhosa, franca e atenta. 
A dívida que guardo com Fernando Antônio, por ter conseguido ingressar no mestrado da UNB é tão grande que é impossível descrever, mas, para ilustrar e prestar testemunho de seu caráter, basta dizer que ele nunca considerou assim e eu sempre soube disso. A Francisco Mendes, que, literalmente e por escrito, me pediu, por favor, para eu fazer a minha inscrição no programa, agradeço prometendo nunca esquecer o acompanhamento inteligente, experiente e sensível de todos os meus passos, do começo ao fim. Não é possível fracassar, com amigos assim.

Reconheço, com orgulho, a influência da minha família, paterna e materna, que sempre esteve ao meu lado nessa difícil trajetória de estudos, desde o interior do Piauí até essa instituição maravilhosa que é a UNB. A meus irmãos, Cortez e Lêda, e ao meu sobrinho João, comovidamente lembro que a sua simples existência ilumina minha vida, e me dá a força moral e a coragem para seguir tentando honrar o legado de papai e mamãe, que é, acima de tudo, nossa educação. A Maria Tereza, companheira fiel e torcedora entusiasmada, penhoro meu amor. 
"Ao culpado que cair debaixo da tua jurisdição, considera-o como um mísero, sujeito às condições da nossa depravada natureza, e em tudo quanto estiver da tua parte, sem agravar a justiça, mostra-te piedoso e clemente, porque ainda que são iguais todos os atributos de Deus, mais resplandece e triunfa aos nossos olhos o da misericórdia que o da justiça"

Conselho de Dom Quixote de La Mancha a Sancho Pança, Governador da Ilha Barataria

Em memória de Joaquim e Terezinha Rufino. 


\section{Resumo}

O objetivo da presente dissertação é analisar o programa de leniência antitruste brasileiro, além de outros assemelhados, extrair algumas características essenciais e avaliá-las de acordo com a teoria dos jogos. Para tanto, é feita uma descrição sumária da teoria dos jogos e explicada suas adaptações ao direito antitruste, através da demonstração do dilema do prisioneiro aplicado a uma situação em que os infratores praticaram cartel. Nesse primeiro momento, conclui-se que os incentivos básicos para a confissão resultantes do dilema do prisioneiro são pequenos, quando a autoridade não tem conhecimento prévio da existência de um ilícito, e fortes, quando já há pelo menos uma confissão anterior. Posteriormente são descritos os programas de leniência dos Estados Unidos da América, da União Europeia e do Brasil. Com base nessa descrição, são separados quatro elementos presentes em todos os programas de leniência examinados: (a) previsibilidade quanto aos requisitos, procedimentos e benefícios esperados; (b) existência de determinados graus de sigilo das negociações e das informações trocadas; (c) estabelecimento de incentivos para uma corrida para a confissão; (d) técnicas de comprovação documental da narrativa do delator. Cada elemento é, então, avaliado de acordo com o conjunto de incentivos básicos derivado da teoria dos jogos. A partir destas premissas, argumenta-se que a previsibilidade do programa é essencial para facilitar a tomada de decisão pela confissão, em um ambiente de incentivos baixos. É demonstrado que o sigilo garante as condições para as negociações conducentes à delação, protege o avanço da investigação e impede que o delator sofra consequências mais gravosas que os denunciados. A existência de normas que fomentem uma corrida pela delação é avaliada como elemento deflagrador do receio de ser delatado e, portanto, funciona como o maior incentivo pela confissão. Também é defendido que deve haver normas voltadas a estabelecer outras corridas após a primeira delação. A necessidade de documentação da narrativa é apresentada como remédio para que incentivos perversos não contaminem o processo de formação de uma confissão útil. Conclui-se, ao final, que a conjunção desses quatro elementos, quando devidamente estruturada, propicia a formação de um programa de leniência consistente com os incentivos para a confissão derivados da teoria dos jogos.

Palavras-chaves: Direito da Concorrência. Combate a cartéis. Programa de Leniência. Teoria dos Jogos. Incentivos para a confissão. 


\begin{abstract}
The purpose of this work is to analyze the Brazilian antitrust leniency program and other similar programs, draw some of their essential characteristics and evaluate them according to the game theory. Therefore, it makes a brief description of such theory and explains how it is adapted to antitrust law, by demonstrating the prisoner's dilemma applied to a situation in which offenders are involved in a cartel. Firstly, it concludes that the basic incentives for confession that emanate from the prisoner's dilemma are small when the authority has no prior knowledge of the infringement and strong when there is already at least one previous confession. Next, the works describes the leniency programs of the United States, of the European Union and of Brazil. Based on this description, it identifies four elements that are present in all leniency programs under analysis: (A) predictability regarding the requirements, procedures and expected benefits; (B) the existence of certain degrees of confidentiality of the negotiations and of the information exchanged; (C) incentives that lead to a race to confess; (D) techniques that evidence through documents the informant's narrative. The work then evaluates each element in light of the basic set of incentives derived from the game theory. Considering these premises, it argues that, in a low incentive environment, the program's predictability is essential to facilitate agents to make a decision towards confessing. It shows that confidentiality not only assures the necessary conditions for the negotiations that tend to lead to confession, but it also protects the progress of the investigation and prevents the informant from being placed in a worse position than those who do not cooperate. The existence of rules that stimulate a race to confess is considered the element that triggers the fear of being denounced and therefore functions as the greatest incentive for confession. The work also argues that there should be rules aimed to establish other races after the first confession. The need for documenting the narrative is presented as a remedy that prevents perverse incentives from contaminating the development of a useful confession. Finally, the work concludes that the combination of these four elements, when properly structured, underpin the development of a leniency program that is consistent with the incentives for confession emanating from the game theory.
\end{abstract}

Keywords: Competition Law. Fighting cartels. Leniency Program. Game Theory. Incentives for confession. 


\section{Sumário}

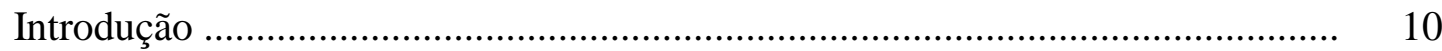

1. A Teoria dos Jogos e sua relação com programas de leniência ........................ 19

1.1. Teoria dos Jogos: Conceitos básicos ................................................ 20

1.2. Jogo, Jogadores, Estratégias e Resultados ........................................ 21

1.3. Racionalidade e Inteligência …...................................................... 22

1.4. O exemplo da Batalha do Mar de Bismarck ........................................ 23

1.5. O equilíbrio de Nash ................................................................... 27

1.6. O dilema do prisioneiro ..................................................................... 27

1.7. As adaptações de Cristopher Leslie do dilema do prisioneiro à 30

leniência no direito antitruste ...........................................................

1.8. Conclusões .................................................................................. 34

2. A inserção dos programas de leniência no antitruste ..................................... 36

2.1. O Programa de Leniência dos Estados Unidos da América ................ 36

2.2. O Programa de Leniência da União Europeia ...................................... 41

2.3. O Programa de Leniência do Brasil ....................................................... 45

2.4. Conclusões................................................................................. 49

3. Avaliando os elementos centrais de um programa de leniência ....................... 49

3.1. Previsibilidade .............................................................................. 50

3.1.1. O gozo do benefício deve ser certo ......................................... 51

3.1.2. O procedimento deve ser claro ................................................. 54

3.1.3. A autoridade deve ser confiável .............................................. 56

3.2. Sigilo ................................................................................. 59

3.2.1. O sigilo protege a investigação que se inicia .............................. 60

3.2.2. O sigilo garante um ambiente favorável à negociação .................. 61

3.2.3. O sigilo suaviza os custos de entrada na negociação ................... 63

3.2.4. O sigilo evita que o colaborador esteja em inferioridade ............. 65

3.2.5. Conclusões ........................................................................ 69

3.3. Corrida pela delação ……………......................................................... 70

3.3.1. O papel da preempção .............................................................. $\quad 70$

3.3.2. Penas severas reforçam a corrida ................................................ 72

3.3.3. O procedimento como um fomentador da corrida ....................... 74

3.3.4. As corridas deflagradas após a primeira ..................................... 77

3.4. Documentação ............................................................................ 80

3.4.1. A confissão e suas vulnerabilidades ......................................... 82

3.4.2. A documentação mitiga os problemas da confissão .................... 84

3.4.3. O risco de sobredelação e subdelação ........................................... 85

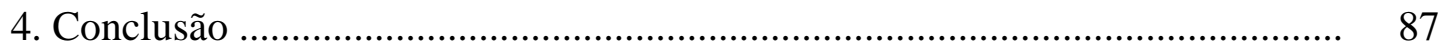

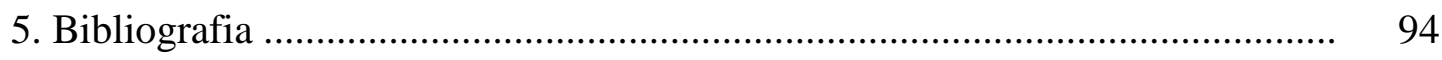




\section{Introdução}

O objetivo da presente dissertação é analisar o programa de leniência brasileiro e assemelhados, de forma a extrair algumas das suas principais similaridades e examiná-las, através da aplicação da teoria dos jogos, para inferir de que maneira devem ser manipuladas para obter o maior número de confissões, com o maior grau de precisão, pelo menos de acordo com os incentivos básicos previstos na teoria dos $\operatorname{jogos}^{1}$.

É impossível acompanhar o debate público no país atualmente sem se deparar com instigantes discussões sobre a colaboração de investigados com as autoridades investigadoras em troca de benefícios para aqueles, por meio de delações premiadas ou acordos de leniência.

\section{Esquemas de delação premiada na legislação brasileira}

A tradição jurídica nacional, ao menos no período recente, não incorporava de forma significativa a utilização deste tipo de instrumento, mantendo com ele uma relação ambígua (PASTRE, 2005). A nossa tradição política repudia a figura do delator $^{2}$, na pessoa de Joaquim Silvério dos Reis, desde a época colonial. A tradição religiosa associa a delação a Judas Iscariotes, grande traidor na representação cristã.

Não obstante, a questão está posta e a quantidade de eventos de grande impacto, deflagrados por meio de uso de ferramentas que incorporam a lógica da barganha com o participante da infração, impõe uma reflexão mais aprofundada sobre o tema.

\footnotetext{
${ }^{1}$ É importante asseverar que não é objetivo da presente dissertação avaliar a utilidade/eficiência deste instrumento na política de defesa da concorrência (matéria meritória e que também merece exame), ou em qualquer outro campo, ou mesmo se o objetivo de obter o maior número de delações deve ser perseguido. Assume-se que, quando programas dessa natureza são instituídos, essa é a intenção.

${ }^{2}$ Apesar da carga negativa normalmente associada à palavra, o presente trabalho usará a palavra delator como sinônimo de beneficiário da leniência, colaborador, etc., com um sentido absolutamente neutro. Do mesmo modo, o uso de expressões como parceiros, co-partícipes, cúmplices ou comparsas, dá-se por razões de exposição, sem qualquer juízo de valor por parte do autor.
} 
Não é coincidência que tal ocorra precisamente em relação a infrações de cunho econômico, praticadas por agentes com alto poder político e/ou financeiro, com severos efeitos negativos no funcionamento do Estado, do ambiente econômico e da própria coesão social (SCHINKEL, 2008, p. 6). Como será explicado, é em ilícitos com estas feições que o instituto tende a ser mais eficaz e necessário.

As sucessivas delações que são relatadas diuturnamente pela mídia na cobertura jornalística da cognominada "operação lava-jato" se dão através de mecanismo jurídico de introdução recentíssima na legislação nacional, especificamente na Lei 12.850, de 02 de agosto de 2013, chamada "Lei das Organizações Criminosas".

Os acordos de leniência previstos na recente Lei 12.846 (Lei Anticorrupção ou Lei da Empresa Limpa), de 01 de agosto de $2013^{3}$ e na Lei 12.529 , de 30 de novembro de 2011, também observam lógica similar à colaboração premiada prevista na Lei 12.850/2013: o investigado coopera com o investigador na identificação do ilícito e seus demais praticantes em troca de benefícios relacionados à isenção ou redução de penalidades potencialmente aplicáveis.

Todos pertencem à antiga linhagem da delação premiada, presente no direito brasileiro, segundo Damásio de Jesus (2005), desde as Ordenações Filipinas, passando pelas Leis 8.072/90 e 9.269/96; § $2^{\circ}$, do art. 24, da Lei 7.492/86, acrescentado pela Lei 9.080/95; par. único do art. 16, da Lei 8.137/90, acrescentado pela Lei 9.080/95; art. $6^{\circ}$, da Lei 9.034/95 e $\S 5^{\circ}$, do art. $1^{\circ}$, da Lei 9.613/98, Código Penal, (art. 159, $\S 4^{\circ}$ ), (BOLDT, 2005, p. 3).

O que os distingue como espécie particular do gênero "delação premiada" são dois fatores: (i) a sua relação comum, expressa na identidade da conformação dos dispositivos legais que os instituem (art. $4^{\circ}$ da Lei 12.850/2013, art. 16 da Lei 12.846/2013 e art. 85 da Lei 12.529); (ii) a sua inserção em normas voltadas, fundamentalmente, ao combate de práticas ilícitas de alto grau de sofisticação, cujo benefício pretendido pelos infratores é de natureza eminentemente econômica (GREGHI, 2007).

\footnotetext{
${ }^{3}$ Não coincidentemente promulgada apenas um dia antes da Lei 12.850/2013.
} 
Pode-se convencionar, assim, que a Colaboração Premiada da Lei 12.850/2013 e os Acordos de Leniência da Lei 12.846/2013 e da Lei 12.529/2011 (Lei de Defesa da Concorrência), pertencem a uma espécie moderna do gênero "delação premiada" no direito brasileiro.

\section{O acordo de leniência como ferramenta de combate ao ilícito de colarinho branco}

$\mathrm{O}$ entendimento da questão aqui discutida passa, em primeiro lugar, pela delimitação dos problemas enfrentados pelas autoridades competentes para a persecução de ilícitos dessa natureza e, em segundo lugar, pela compreensão das suas características básicas, para que, então, se possa avaliar os mecanismos utilizados no seu combate e como podem ser estruturados.

Dificilmente pode haver tarefa de investigação mais árdua que tentar descobrir e punir ilícitos que quase não deixam traços materiais e, não obstante, são de elevada nocividade, praticados por infratores com grande nível de sofisticação e consciência das suas atividades, mas esta é, precisamente, a posição em que se encontram aqueles que são responsáveis pela persecução penal (a palavra penal aqui entendida em seu sentido mais amplo, incluindo a persecução penal e administrativa) de ilícitos de colarinho branco.

Adicione-se a isso as limitações, naturais e necessárias, decorrentes do Estado Democrático de Direito, que se apresentam em um arcabouço de práticas de investigação bem delineado e restrito, na necessidade de a imputação ser detalhada e provada e no respeito a garantias formais e materiais de defesa extensas (MENDES, COELHO e BRANCO, 2008, p. 546).

Como afirmado, ilícitos de colarinho branco em geral não deixam marcas, tal qual um furto que se percebe pelo desaparecimento do objeto da ação, ou um assassinato que se perfaz no corpo falecido da vítima. $\mathrm{O}$ aumento de preços decorrente de um cartel dificilmente pode ser comparado, no mundo extramente complexo das transações econômicas, com o preço que poderia ter existido caso a competição tivesse ocorrido de forma plena. A licitação fraudada em conluio entre empresários, 
funcionários públicos e políticos, permanece, à falta de prova contundente, no máximo, como um preço alto pago por um Estado perdulário e engessado.

Ao investigador restam apenas conjecturas, baseadas em comparações, frequentemente de índole econômica/estatística, que podem ser suficientes para ampliar o grau de incerteza sobre o evento em si, mas, dificilmente, aptas a justificar uma merecida repressão (ANDERSON, BOLEMA e GECKIL 2007, p. 2).

Por outro lado, os infratores aqui não podem ser comparados ao criminoso que segue sua jornada delitiva desacompanhada e vulnerável aos percalços que a marginalidade impõe. O praticante, por definição, é pessoa, física ou jurídica, dotada de condições materiais e intelectuais de compreender plenamente o caráter ilícito dos seus atos e, portanto, se prepara para agir de forma a esconder, camuflar ou apagar os elementos que podem permitir a identificação de sua conduta (BRAITHWAITE, 1985, p. 3).

Mais importante, em geral não o faz sozinho, mas sim com o apoio dos seus comparsas e de um aparato técnico e jurídico hábil a implementar a estratégia delituosa com sucesso, muitas vezes através do uso de ferramentas extremamente sofisticadas (BRAITHWAITE, 1985, p. 7-9).

Os participantes do conluio criminoso (a palavra crime aqui utilizada, de igual modo, em sua acepção mais ampla, envolvendo crimes propriamente ditos e infrações administrativas), por sua vez, possuem diversos incentivos a perpetuarem a prática. Os ganhos econômicos (ou mesmo políticos) tendem a ser substanciais e a passagem do tempo sem detecção do ilícito fortalece os laços de confiança que são essenciais ao sucesso dessas organizações (LESLIE, 2004, p. 549).

Diante desse quadro, contudo, o que permanece são práticas ilícitas com efeitos negativos sérios.

\section{O exemplo dado pelos cartéis}


Apenas para se ter uma dimensão da natureza do problema, uma análise de preços da chamada "operação 274", que consistiu em operação de busca e apreensão para investigar cartelização no mercado de combustíveis da cidade de João Pessoa, Estado da Paraíba, detectou uma queda de preços significativa nos preços praticados nos meses seguintes à deflagração da busca e apreensão:

Gráfico 1 - Impacto da Operação 274 no preço e consumo de Gasolina. Fonte: (CADE e SEAE, 2009).

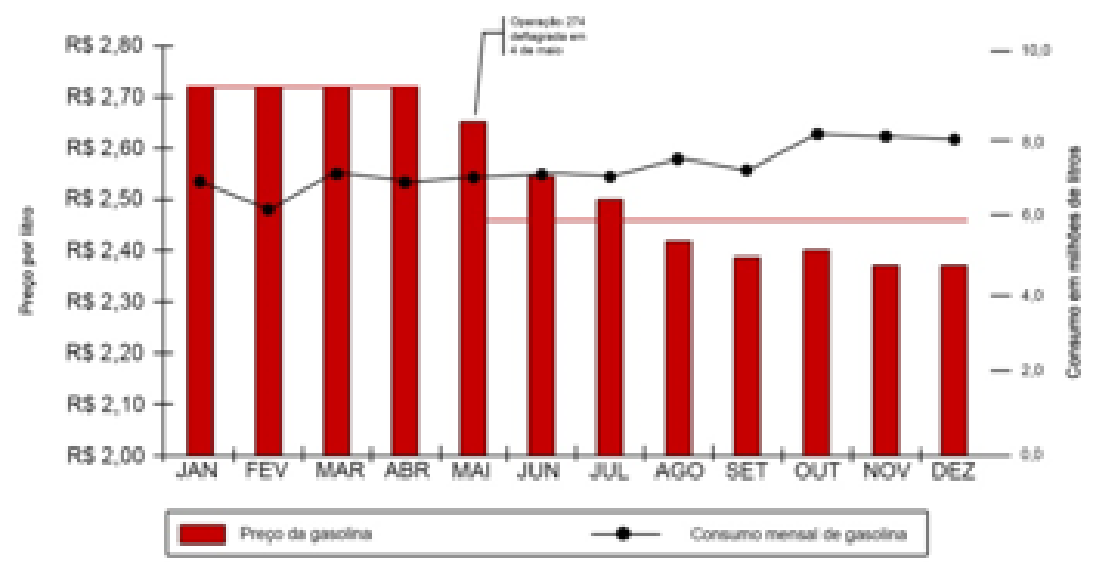

O ilícito cartel, como se pode perceber, se encaixa elegantemente nas características acima delineadas.

O foco em cartéis que será adotado nesta dissertação dá-se por razões metodológicas e de economia na exposição. No entanto, como será visto, as lições extraídas da política de combate a cartéis podem ser utilizadas, com as devidas adaptações, no combate a qualquer tipo de infração que compartilhe com o cartel estas características essenciais, ou seja, parcela significativa dos ilícitos de colarinho branco que envolvem algum tipo de coordenação ${ }^{4}$.

As formas de operação tradicional de um cartel são a fixação de preços, a divisão de mercado, geográfica ou por produtos, e o controle da oferta. Todas resultam em algum nível de aumento de preços e, mais importante, tem como prérequisito a cooperação continuada dos agentes em um período razoável de tempo.

\footnotetext{
${ }^{4}$ Algumas das ideias adiante desenvolvidas já foram expostas em trabalho anterior do autor (RUFINO, 2015).
} 
Spagnolo (2005b, p. 2) associa a pratica de cartel a outros tipos de condutas ilícitas coordenadas, como corrupção, cooperação entre reguladores e regulados ou auditores e auditados, para diferenciá-las de atividades criminosas padrão, quando atos ilícitos se exaurem em um único ato de indivíduos isolados.

Ao fazer a distinção, Spagnolo (2005b, p. 2) extrai três principais características de práticas colusivas que se protraem no tempo: (i) a cooperação é necessária para o sucesso da prática, pois existem incentivos diversos para a adoção de condutas oportunistas e, ao mesmo tempo, não existem mecanismos explícitos de governança, como cláusulas contratuais mandatórias para garantir o enforcement das regras dos cartéis, embora exista exemplo folclórico no Brasil onde um acordo de preços, intitulado de "convenção", foi registrado em cartório por empresas que comercializavam extintores de incêndio no Distrito Federal (CADE, 2014a); (ii) como decorrência da primeira característica, cartéis se desenvolvem através de uma dinâmica que tem que apresentar certa permanência no tempo, pois, ausentes mecanismos de enforcement exógenos, os próprios integrantes do cartel devem garantir o seu funcionamento e o fazer através da instituição de mecanismos internos - e ilícitos - de governança, como no caso brasileiro do "cartel das britas", onde se verificou a presença de "auditores" do cartel, autorizados a analisar a atividade interna de todos os integrantes, para identificar e punir comportamentos indesejáveis, como vendas a cliente alocadas para parceiros no conluio (CADE, 2005); (iii) como consequência das duas características acima, cartéis e demais organizações ilícitas, diferentemente de ilícitos praticados isoladamente, se desenrolam com cada infrator conhecendo e, possivelmente, detendo provas, da participação dos demais.

\section{O pioneirismo do antitruste no uso de acordos de leniência}

Não se deve ao acaso o fato de a Lei de Defesa da Concorrência ser a menos recente das três acima citadas. O combate a cartéis no país incorpora, desde os anos 90, técnicas oriundas do direito norte-americano, mais amigável à utilização deste tipo de instrumento (SCHWARTZ, 2006). 
Com isso, ao contrário da esfera criminal e do combate à corrupção, o direito antitruste oferece um maior e mais estável número de exemplos, normativos e práticos, que servem de referencial para as demais áreas e, desta forma, seu estudo pode ser de grande valia para a compreensão desse fenômeno.

A inserção do programa de leniência na legislação nacional deu-se paralelamente à disseminação de sua utilização em diversos países, iniciada após a reformulação do programa de leniência do Departament of Justice (DoJ) dos Estados Unidos da América em 1993 (SPAGNOLO, 2005a, p. 2). Desde esse período, a quantidade de confissões apresentadas ao governo americano se multiplicou 20 vezes (HAMMOND, 2009, p. 2), encorajando outras jurisdições a também adotarem o instrumento.

Tal movimento visou incrementar a política de combate a cartéis através do aumento da capacidade de detecção pelas autoridades investigatórias oriundo de confissões obtidas de participantes (MARTINEZ, 2013, p. 259).

O apelo do mecanismo é óbvio.

As autoridades investigatórias, sobretudo a antitruste, sofrem as limitações materiais, de pessoal, orçamentárias, etc., ao mesmo tempo em que sua jurisdição se espraia por toda a atividade econômica que, naturalmente, é palco constante deste tipo de conduta (MENDES, 2012, p. 27-31).

As características intrínsecas de um cartel, como visto, dificultam sua detecção independente pelos investigadores. Inferir um conluio pela evolução dos preços é possível, porém de eficácia restrita (HEYER, 2005, p. 8-9). A denúncia por consumidores ou outros entes ligados ao mercado afetado é útil, mas esbarra na coleta da prova cabal requerida para a condenação.

A descrição da conduta por um dos seus participantes, por outro lado, permite ao investigador acessar a mecânica interna do cartel e, desta forma, circundar as inúmeras dificuldades que se apresentam no tocante à obtenção independente de provas da prática da infração, seus sujeitos e mesmo os efeitos por ela produzidos. 
Um delator pode desvendar as sofisticadas técnicas de acobertamento do ilícito, apresentar documentos que comprovem os acertos, indicar os participantes, modus operandi, apontar linhas de investigação e trazer uma infinidade de provas materiais que de outra forma seriam de acesso impossível ou, mesmo que acessíveis, de significado arcano para um ente externo à organização criminosa.

Logo, não é de se estranhar que autoridades responsáveis pelo combate a prática de cartéis tenham paulatinamente buscado a colaboração dos próprios infratores no desvelar deste tipo de ilícito (MOTTA e POLO, 2003, p. 348-350).

Ocorre que, naturalmente, praticantes de um ilícito tendem a não cooperar com autoridades cuja principal função é puni-los por suas atitudes delituosas. Provavelmente apenas o farão, sobretudo se a autoridade ainda não tiver nenhum conhecimento sobre a prática, se enxergarem benefícios tangíveis que possam aferir a partir da colaboração.

Programas que envolvem delações, portanto, trazem em si arranjos que preveem ganhos recíprocos, entre investigadores e investigados colaboradores, no engajamento que leva à confissão, com medidas que incluem a concessão de benefícios ao infrator que confessa, especialmente através da redução - ou completa abstenção - da punição legalmente devida pelos atos ilícitos por ele praticados. Daí o nome leniência, a aludir à complacência da autoridade punitiva com o transgressor que coopera.

$\mathrm{Na}$ seara antitruste, este tipo de programa proliferou, a partir dos anos 90, sendo adotado em quase todas a jurisdições relevantes na arena internacional (GRIFFIN, 2003).

O programa de leniência brasileiro está sendo aplicado há mais de uma década, com aproximadamente 54 acordos de leniência já assinados (CADE, 2016a) e contando com profusa regulamentação infralegal, ao contrário das outras duas modernas delações premiadas do direito brasileiro.

\section{A função explicativa da teoria dos jogos}


A teoria dos jogos, muito desenvolvida pelo matemático ganhador do Nobel John Nash, fornece um importante instrumental para a compreensão da estrutura de incentivos existente para que determinado agente racional opte pela tomada de decisão pela confissão de sua participação em um determinado ilícito.

Há diversos trabalhos analisando a influência que a conformação normativa de um programa de leniência tem para reforçar a quantidade e a qualidade de confissões de participações em cartéis (HARRINGTON, 2005, p. 01). Há trabalhos, inclusive, que oferecem críticas substantivas ao instituto, através da elaboração de modelos que medem o impacto de determinadas configurações de uma política de leniência (SPAGNOLO e BUCCIROSSI, 2005; CHANG e HARRINGTON, 2009).

O objetivo do presente texto é fazer uma análise crítica de trabalhos dessa natureza e tentar extrair algumas noções básicas sobre o funcionamento e modelagem de um programa equivalente.

É notório que há uma tendência de disseminação de políticas de fomento à delação no direito brasileiro, sendo esta uma realidade cada vez mais presente, como se observa, por exemplo, de tentativas já adiantadas de implementação de estratégias similares no âmbito de atuação do Banco Central e da Comissão de Valores Mobiliários $^{5}$. Assim, é oportuno desenvolver um instrumental de referência para a criação e aperfeiçoamento de programas de leniência.

Por este motivo, é objetivo da presente dissertação explicar os incentivos básicos para a confissão ou não-confissão de um cartel, à luz da teoria dos jogos. A partir daí, perquirir a estruturação de programas de investigação que exploram estes incentivos no sentido de obter confissões de cartéis no mundo, em geral, e no Brasil, em particular, com a descrição de suas características mais relevantes.

Posteriormente, se extrairá algumas características comuns a estes programas, tais como previsibilidade de regras, sigilo na aplicação prática do programa, criação de incentivos que estimulem uma corrida para a confissão e utilização de estratégias de checagem das informações prestadas pelo colaborador. 
Estas características comuns, então, serão avaliadas à luz da teoria dos jogos, para se inferir as principais consequências da adoção de um ou outro modelo específico.

Quando possível, essas características serão comparadas com outros modelos de leniência previstos na legislação nacional, para se chegar a algumas conclusões sobre modelagens que podem ser eficientes, sob o palio da teoria dos jogos, para obter confissões úteis à persecução de ilícitos semelhantes.

\section{A teoria dos jogos e sua relação com programas de leniência}

O presente trabalho, evidentemente, não se propõe a exaurir a teoria dos jogos. Marco teórico ainda em franca expansão e utilizado em diversos ramos da ciência, tais como economia, biologia, sociologia, etc., a teoria dos jogos apresenta incontáveis nuances e problemas que requerem profunda e constante reflexão, que fogem ao escopo da dissertação e da expertise do autor.

As muitas implicações matemáticas do tema, por sua vez, serão evitadas ao máximo, procurando-se sempre a simplificação na exposição, que deve ser particularmente acessível aos operadores da ciência jurídica. As explicações e exemplos oferecidos, por conseguinte, tenderão a se utilizar de referências numéricas simples e serão reduzidas ao estritamente necessário à compreensão da ideia em discussão.

O uso da teoria dos jogos no presente trabalho será direcionado a compreender os seus elementos básicos e, a partir deles, condensar modelos que permitam intuir os incentivos envolvidos na prática de cartel e na eventual decisão de cooperar com investigadores em troca de benefícios através da confissão. Apenas o que se subordinar a este fim será salientado. Faz-se isso, para manutenção da objetividade do trabalho, evitando-se expansões desnecessárias, na certeza de que fontes mais

\footnotetext{
${ }^{5}$ Em outubro de 2015 foi noticiado texto de Medida Provisória em discussão interna para instituir programas de leniência no âmbito das atribuições do Banco Central do Brasil e da Comissão de Valores Mobiliários: http://jota.uol.com.br/planalto-prepara-mp-para-reformar-2a-instancia-de-bc-e-cvm
} 
autorizadas serão muito mais úteis ao leitor curioso que deseja inquirir vigorosamente o tema.

\subsection{Teoria dos Jogos - Conceitos básicos}

Como afirmado na introdução, a teoria dos jogos é comumente associada ao trabalho do matemático John Nash, tema de livro e filme de grande sucesso (NASAR, 2011), e que, efetivamente, como será visto, ofereceu influência decisiva para o seu avanço. Anteriormente a Nash, foi a obra de John Von Neumann e Oskar Morgenstern (VON NEUMANN e MORGENSTERN, 1990), na década de 40, que estabeleceu as bases modernas da teoria dos jogos. A partir dos anos 50 iniciou-se a sua disseminação, especialmente através da aplicação aos campos militares e de guerra nuclear, tendo especial destaque a profusa produção da RAND Corporation, think thank da Califórnia especializado em defesa que se notabilizou por pesquisas voltados ao desenvolvimento de estratégias militares na guerra fria (HARGREAVES-HEAP e VAROUFAKIS, 1995, p. 50).

Um aspecto atraente da teoria, e que muito influenciou sua difusão, é a associação com um jogo. A sintetização de interações complexas, entre agentes plurais com posições e objetivos estratégicos distintos, em formulações de jogo, muitas vezes de forma surpreendentemente simples, confere à teoria dos jogos o papel de parâmetro atraente para a compreensão de uma gama variada de situações.

A principal ferramenta que a teoria dos jogos fornece é a construção de modelos descritivos que buscam simplificar as situações objeto de estudo, e, embora alguns modelos possam ser sofisticados matematicamente, é possível desenvolver sublimações acessíveis a qualquer leitor (KAPLOW e SHAVELL, 2004, p. 35), o que é frequentemente feito por estudiosos, como será demonstrado.

Naturalmente, como qualquer modelo, redutor de complexidade, há que se guardar respeito às limitações subjacentes e, desta forma, a correta afirmação das premissas operacionais do modelo e dos objetivos a que ele se propõe são essenciais para sua utilidade. Contudo, uma vez bem aplicado, a sua fertilidade é notável. 
Delimitando o objetivo da modelagem que será adiante desenvolvida, reafirme-se, a intenção é apresentar a estrutura básica de incentivos que um agente envolvido na prática de cartel enfrenta quando colocado diante da possibilidade de delatar o esquema ilícito, em troca da leniência da autoridade investigadora, ou persistir na ilegalidade, com os ganhos daí decorrentes.

Entretanto, algumas premissas ínsitas à teoria dos jogos precisam ser exploradas antes de se adentrar nesta tarefa.

A primeira delas é a descrição do jogo, jogadores, estratégias e resultados (CALLIARI, 2003, p. 8).

\subsection{Jogo, Jogadores, Estratégias e Resultados}

Há um jogo sempre que um conjunto de agentes interagir em um ambiente comum, adotando cada qual sua respectiva estratégia, em busca de resultados que cada um desses agentes definir como convenientes (BINMORE, 2007, p. 1). Pode-se inferir, daí, que os elementos básicos do conceito de jogo são o jogador, o espaço estratégico e o resultado (CALLIARI, 2003, p. 8).

Os jogadores podem ser uma pessoa, empresa, estado, organização ou qualquer combinação destes, desde que movidos por um interesse comum, ainda que eventualmente se admita divergências internas, que influenciem o seu comportamento (BINMORE, 2007, p. 4). Em geral, os modelos apresentam jogos com apenas dois jogadores, embora existam versões mais complexas (McCARTY e MEIROWITZ, 2007, p. 171-176).

O espaço estratégico de cada jogador, por seu lado, define-se como as possíveis escolhas que um determinado jogador tem em um jogo. Os jogos mais simples apresentam duas opções, embora, tal qual ocorre com os jogadores, possa haver situações com uma pluralidade de ações possíveis, inclusive no curso do próprio jogo (CALLIARI, 2003, p. 9). O bom desenho do espaço estratégico é fundamental para que sejam identificados os elementos essenciais envolvidos no jogo analisado.

O resultado, também chamado de pay-off, é o valor atribuído pelo jogador para cada combinação de estratégias observada em determinado modelo (CALLIARI, 
2003, p. 10). Normalmente está expresso numericamente, indicando intensidade, positiva ou negativa, ou uma ordem de preferência. Trata-se da variável chave no desenho de um jogo, pois é a preferência por cada resultado que determinará as estratégias adotadas e permitirá ao observador entender a estrutura de incentivos dos jogadores e o próprio jogo.

No entanto, o balizamento dos principais elementos do jogo é insuficiente para o seu completo entendimento. É necessário, ainda, estabelecer as premissas que definirão o comportamento dos jogadores. Aqui se destacam os conceitos de racionalidade e inteligência (CALLIARI, 2003, p. 11).

\subsection{Racionalidade e Inteligência}

A teoria dos jogos opera com a premissa de que os jogadores são racionais. Abstração com objetivos funcionais, a racionalidade pressupõe que os jogadores adotarão comportamentos que sejam consistentes com a obtenção de resultados de sua preferência (CALLIARI, 2003, p. 11-15). Assim, se um investigado prefere ficar livre a ser preso por 1 ano e ser preso por 1 ano a ser preso por 2 anos, tomará decisões consistentes com estas preferências.

Orientando a racionalidade, estão os conceitos de utilidade, transitividade e completude (CALLIARI, 2003, p. 11-15).

Especificamente para a teoria dos jogos, Von Neumann e Morgenstern, por meio do teorema da maximização da utilidade esperada (BINMORE, 2007, p. 5-7) definem que qualquer agente racional confere valores aos resultados possíveis em um determinado jogo, indicando assim a sua ordem de preferência e tomando suas decisões de forma a maximizar a utilidade esperada. É a partir da atribuição de valores de utilidade em um jogo que se pode prever como cada jogador se comportará.

Embora tais valores de utilidade possam ser expressos em indicadores monetários, por exemplo, em extrema simplificação, é certo que elementos intangíveis podem nele ser incorporados. O importante é que a utilidade esperada reflita realisticamente a escala de relevância que o jogador imprime a cada resultado. 
Da utilidade desdobram-se a transitividade e a completude. Pela transitividade, um jogador que prefere ficar livre a ser preso por 1 ano e ser preso por 1 ano a ser preso por 2 anos, prefere ficar livre a ser preso por 2 anos. Já a completude significa que determinado jogador pode comparar todos os resultados possíveis, ordenando-os de acordo com sua utilidade, e manifestando sua indiferença a alguns (CALLIARI, 2003, p. 14-16).

A outra premissa operacional relevante da teoria dos jogos é a inteligência dos jogadores. Assume-se que os jogadores conhecem os demais participantes, as regras, as opções estratégicas de todos e suas preferências. Assim, tomam suas decisões conscientes das limitações a si impostas e aos demais componentes (HARGREAVESHEAP e VAROUFAKIS, 1995, p. 45-46).

As premissas de racionalidade e inteligência estão sujeitas a limitações epistemológicas indubitáveis. Todavia, descartá-los e adotar a irracionalidade e ausência de inteligência dos jogadores não parece uma alternativa superior. A adoção das premissas, com as devidas cautelas e consciência de sua insuficiência, pode prover instrumental analítico poderoso.

A descrição de um exemplo clássico de jogo ajudará a compreender melhor os conceitos acima narrados e permitirá a introdução de outros, não menos significativos.

\subsection{O exemplo da Batalha do Mar de Bismarck}

Um caso verídico analisado em 1954 por Haywood (1954) e repetido em outras publicações (CALLIARI, 2003 e LIU, 2015) refere-se à Batalha do Mar de Bismarck, que ocorreu no ano de 1943, no teatro do pacífico na segunda guerra mundial. O nome é dado pelo Mar de Bismarck, que se situa na parte leste da Oceania e banha o arquipélago das Ilhas Bismarck, dentre elas a ilha da Nova Bretanha.

Um comboio de navios japoneses estacionado na ilha da Nova Bretanha, que a época era o país que as ocupava, recebeu a ordem de entregar suprimentos, tendo de circundar a ilha, saindo do lado oeste e entregando a carga na margem leste. Portanto, deveria optar por navegar pela trajetória norte ou sul. O deslocamento duraria três 
dias. Pela rota norte, esperava-se clima chuvoso. Pela rota sul, as condições climáticas eram mais amenas. Se escolhessem a rota norte e fossem patrulhados pelos americanos, os japoneses sabiam que teriam um dia a menos de bombardeio devido ao clima adverso. O mesmo não poderia ser dito da rota sul.

Os militares americanos, por sua vez, possuíam informações de inteligência que permitiam saber o dia da partida japonesa, mas não a rota. Além disso, tinham material bélico suficiente para patrulhar apenas uma das rotas por dia, de forma que estavam obrigados a escolher cuidadosamente qual trajeto guardar. Se se dirigissem ao norte e os japoneses optassem pela via sul, os americanos perderiam um dia de bombardeio, mesmo com as condições climáticas favoráveis. Se o contrário ocorresse, a perda decorrente do dia necessário à rotação da patrulha e das condições climáticas reduziriam as possibilidades de ataque a apenas um dia.

Os interesses de ambos os lados eram evidentes e contraditórios: os japoneses desejavam diminuir o tempo de exposição aos bombardeios inimigos, os americanos, exatamente o oposto.

Tem-se, aqui, um clássico jogo de soma-zero, onde um ganho de uma parte significa perda da outra. Não necessariamente é essa configuração de todos os jogos, pois há inúmeros exemplos de jogos de índole cooperativa (BRANDENBURGUER, 2007).

Nada obstante, no exemplo em questão, todos os elementos de um jogo são visíveis. Os jogadores são os militares japoneses e americanos, as opções estratégicas de cada lado são a navegação e o patrulhamento aéreo pelas rotas nortes ou sul e os resultados desejados são a minimização ou maximização de exposição da frota de navios. Ambos estão cientes dos riscos, mas não sabem a decisão que o outro lado tomará. Os resultados podem ser expressos de acordo com os dias em que uma investida é viável, nos termos da matriz seguinte: 
Tabela 1 - Matriz da Batalha do Mar de Bismarck. Fonte: elaboração própria a partir de (CALLIAIRI, 2003)

\section{JAPONESES}

\begin{tabular}{|l|l|c|c|}
\cline { 2 - 4 } & & Norte & Sul \\
\cline { 2 - 4 } AMERICANOS & Norte & 2 & 2 \\
\cline { 2 - 4 } & Sul & 1 & 3 \\
\hline
\end{tabular}

O pressuposto da racionalidade, nas suas subdimensões utilidade/transitividade/completude permite a cada lado reconhecer a utilidade de cada estratégia adotada, ordenando-as de acordo com os dias de exposição que entendem ser de seus respectivos interesses. Desta forma, os militares japoneses compreendem que, embora a partida pelo norte com o patrulhamento americano se iniciando no sul seja preferível à partida pelo norte com voos americanos na mesma direção, esta última hipótese é superior à navegação pelo sul com a vigilância inimiga no mesmo sentido.

Do mesmo modo, pelo atributo da inteligência, os militares americanos conhecem as opções japonesas e suas limitações - e o contrário também é verdadeiro - de forma que as condições para uma tomada de decisão em nível estratégico estão dadas e podem ser analisadas mesmo por um observador externo.

O jogo acima narrado está demonstrado na forma padrão de apresentação de modelos de teoria dos jogos. Na matriz descrita - e o caso narrado, lembre-se, é real as partes tomam suas decisões simultaneamente, com os resultados representados em cada célula da matriz, de acordo com o número correspondente ao critério selecionado para o jogo, ou seja, os dias de exposição dos navios ao fogo inimigo. Uma vez que a 
interação das respectivas estratégias leva sempre ao mesmo resultado para os dois jogadores, apenas um número consta em cada célula. Em jogos com pay-offs diversos, para cada par de ações, por exemplo, o número da esquerda representa o resultado do jogador da linha horizontal e o da direita o do jogador da linha vertical (HARGREAVES-HEAP e VAROUFAKIS, 1995, p. 42).

A matriz apresentada, de todo modo, é suficiente para se prever qual conduta será adotada pelos dois lados e a compreensão do conceito de estratégia dominante é a chave para a solução do jogo.

O conceito de dominância pode ser facilmente extraído da observação do jogo em análise. Para o comando japonês, a opção pela rota norte levará a, no máximo, dois dias de bombardeio, independentemente da opção americana. A navegação pelo sul, de seu lado, pode sujeitá-los a dois ou três dias de ataques. O clima, aqui, é crucial, pois fornece um dia de proteção aos japoneses mesmo que os bombardeios americanos acertem a rota adotada desde o primeiro dia.

A estratégia de singrar a norte, portanto, é dominante para os japoneses, pois garante um resultado satisfatório independentemente da estratégia adotada por seu adversário. A estratégia de seguir rumo ao sul é dita, mutatis mutandis, dominada (HARGREAVES-HEAP e VAROUFAKIS, 1995, p. 44). Repare que o conceito de dominância não implica necessariamente a vitória ou a realização da célula mais favorável ao jogador. Naturalmente os japoneses preferem seguir a norte com os americanos patrulhando o sul, hipótese em que serão atacados somente por um dia. No entanto, sem dispor de informações antecipadas sobre a decisão do outro jogador, o que a estratégia dominante garante é uma solução adequada obtida através de uma conduta unilateral.

O lado americano, todavia, não tem uma estratégia dita dominante. A opção de seguir ao sul tanto pode resultar em três dias de bombardeios como em apenas um, e a vigília ao norte garante dois dias de assaltos, número inferior a uma das possibilidades resultantes da adoção da primeira estratégia.

As premissas da racionalidade e inteligência, entretanto, são de grande valia no deslinde do jogo. Os japoneses são racionais e devem tomar suas decisões de forma a 
maximizar sua utilidade, optando, desta forma, pela estratégia dominante que lhes garantirá um ou dois dias de bombardeios apenas. Os americanos são racionais e inteligentes e conhecem as opções nipônicas, podendo, portanto, eliminar a hipótese de que estes navegarão em direção ao sul. Assim, sabem que também devem eliminar essa hipótese, que lhes custaria dois dias de ataque e tendem à direção setentrional. Os japoneses, obviamente, também são inteligentes e sabem que esta deve ser a postura dos seus adversários. Todavia, de nada adiantaria rumarem a sul, pois terminariam na mesma situação de estarem sujeitos a dois dias de investidas.

Foi precisamente o que aconteceu no caso concreto (LIU, 2015, p. 7).

\subsection{O equilíbrio de Nash}

A situação descrita, aliás, representa o que se chama equilíbrio de Nash, assim denominado em homenagem ao matemático John Nash, que primeiro o descreveu. O equilíbrio de Nash ocorre quando os jogadores encontram-se em um ponto de equilíbrio, consistente na impossibilidade de qualquer deles obter um resultado superior através da mudança unilateral de estratégia (BINMORE, 2007, p. 11-14). No exemplo descrito, estabelecida a dominância da opção japonesa de navegar rumo ao norte, a decisão americana estava dada para dirigir-se no mesmo sentido e, a partir de então, uma mudança de planos de quaisquer dos dois lados não representaria nenhum ganho.

A identificação do equilíbrio de Nash é ferramenta importantíssima para a solução de jogos tais como os verificados em uma estrutura básica de um acordo de leniência. Estes, se utilizam, fundamentalmente, de variações do chamado dilema do prisioneiro, que será doravante examinado.

\subsection{O dilema do prisioneiro ${ }^{6}$}

\footnotetext{
${ }^{6}$ Algumas das ideias adiante desenvolvidas já foram expostas em trabalho anterior do autor (RUFINO, 2015).
} 
Elaborado pelo matemático Albert Tucker para tornar intuitiva a uma turma de psicologia a teoria dos jogos em um experimento realizado por pesquisadores na RAND Corporation (SPAGNOLO, 2005b, p. 6), o dilema do prisioneiro é uma explicação simples e poderosa para a mecânica de cooperação ou não-cooperação entre indivíduos racionais. Spagnolo (2005b, p. 6) nota que não é acidental que a forma utilizada para tornar o exemplo mais atraente tenha sido associá-lo a um esquema de delação, considerados os precedentes históricos de utilização deste tipo de mecanismo.

$\mathrm{Na}$ sua postulação clássica, dois indivíduos estão sendo interrogados pela polícia, que possui evidências para condenar ambos a um crime mais leve, e suspeita que tenham praticado um delito mais grave, porém não dispõe de provas suficientes em relação a este.

O crime mais leve, do qual se detém a prova, é punível com pena de prisão de um ano, e o crime mais grave com pena de prisão de três anos. Para a polícia, é interessante condenar ao menos um dos suspeitos pelo delito mais grave. Contudo, prefere condenar os dois. Como não há meios de se obter a prova do delito mais grave de forma independente, a solução é oferecer uma barganha.

A polícia apresenta a cada um dos suspeitos, informando que a oferta é simultânea ao outro e haverá incomunicabilidade, as seguintes opções: a) se o indivíduo confessar o delito mais grave, estará integralmente livre da prisão, caso seu comparsa não confesse, enquanto este ficará preso por três anos; b) se confessar e seu comparsa fizer o mesmo, ambos ficarão dois anos na cadeia pelo delito mais grave; c) se não confessar e seu comparsa fizer o mesmo, ambos ficarão apenas o período de um ano relativo ao delito já comprovado; d) se não confessar e seu comparsa confessar, ficará três anos na cadeia e o outro estará integralmente livre.

O dilema básico é representado na seguinte matriz: 


\begin{tabular}{|c|c|c|}
\hline A & Confessa & Não Confessa \\
\hline Confessa & (2) (2) & 0 \\
\hline Não Confessa & $3 \quad 0$ & 1 \\
\hline
\end{tabular}

O que a matriz demonstra é que, da perspectiva de cada um dos prisioneiros, o dilema é o seguinte: se o seu comparsa confessa, então é melhor confessar e diminuir de três para dois anos seu tempo de prisão. Se o seu comparsa não confessa, continua sendo melhor confessar e evitar o um ano de prisão que já está previsto. Isso torna a estratégia de confessar dominante para as duas partes, pois esta será a escolha mais atrativa independentemente da conduta da sua contraparte.

O paradoxo, para os prisioneiros - não para a polícia, que propositalmente desenhou a oferta - é que ambos estariam em melhor posição se abandonassem a sua estratégia dominante, pois, na ausência de confissão, ficariam restritos ao período de um ano pelo delito já comprovado.

Naturalmente, o dilema em análise ignora, na sua simplificação, diversas nuances próprias da complexidade do mundo real, tais como inclinações por intangíveis como reputação, altruísmo, etc.

Não obstante, a alegoria é altamente instrutiva e, embora seja utilizada como referência em inúmeros campos da atividade humana (BINMORE, 2007, p. 17-21), é particularmente útil, pela sua própria origem, na explicação da dinâmica de um programa de leniência. 


\subsection{As adaptações de Cristopher Leslie do dilema do prisioneiro à leniência no direito antitruste}

Em um alentado estudo sobre a influência da teoria dos jogos na modelagem de um programa de leniência, que servirá de elemento guia para análise do presente texto, o professor americano Cristopher Leslie (2006) faz importantes adaptações do dilema do prisioneiro, para melhor refletir a realidade antitruste.

A primeira delas é relacionada ao fato de que, numa investigação de cartel, inexiste, em regra, um elemento essencial da versão clássica do dilema: os investigadores, geralmente, não possuem um delito comprovado que assegure ao investigado a certeza de que sofrerá algum tipo de punição.

Ausente a ameaça, o dilema reduz-se aos seguintes termos: a) se o indivíduo confessar o delito, continuará livre, caso seu comparsa não confesse, enquanto este ficará preso por três anos; b) se confessar e seu comparsa fizer o mesmo, ambos ficarão dois anos na cadeia; c) se não confessar e seu comparsa fizer o mesmo, ambos continuarão livres; d) se não confessar e seu comparsa confessar, ficará três anos na cadeia e ele continuará livre. A tabela seguinte reflete a adaptação:

Tabela 3 - Dilema do Prisioneiro aplicada ao direito antitruste. Fonte: elaboração própria a partir de (LESLIE, 2006)

\begin{tabular}{|l|rr|rr|}
\hline & B & \multicolumn{2}{|c|}{ Confessa } & \multicolumn{2}{c|}{ Não Confessa } \\
A & & 2 & & 3 \\
\hline Confessa & 2 & 0 & 0 & 0 \\
\hline Não Confessa & 3 & & 0 & \\
\hline
\end{tabular}

$\mathrm{Na}$ situação em que não há uma ameaça concreta, não há estratégia dominante. Ao contrário da versão clássica, a estratégia de confessar não é melhor 
independentemente da estratégia do comparsa, pois, na hipótese de ele não confessar, o indivíduo não estará evitando nenhum tempo de cadeia confessando.

Leslie (2006, pp. 457-458) acrescenta uma dimensão própria do cartel. Ao decidir se confessa, a variável chave do agente não é apenas evitar o tempo de prisão, mas, também, maximizar os seus lucros.

Ao confessar o cartel e, portanto, desmantelá-lo, o participante: (i) renuncia a todos os benefícios colhidos pela prática, tais como os lucros advindos do sobrepreço, (ii) diminui a possibilidade de participar de arranjos ilícitos futuros, devido à perda de confiança de potenciais parceiros; (iii) se expõe a indenizações cíveis pelos danos causados a particulares com a prática; (iv) se expõe a persecuções estatais diversas por ilícitos associados e que não estejam cobertos pela imunidade adquirida na confissão; (v) se o cartel tiver caráter internacional, se expõe à persecução em outras jurisdições; (vi) terá de arcar com os custos de uma investigação demorada, em que será compelido a adotar comportamento cooperativo; (vii) arcará com os danos reputacionais oriundos da investigação.

Todos estes fatores concorrem para retirar a atratividade da opção confessar e, ao mesmo tempo, aumentar a atratividade da opção não confessar. Deve-se ter em consideração, sempre, dada o pressuposto de inteligência já elaborado, que o dilema pressupõe que as partes reconhecem, mutuamente, sua estrutura de incentivos. Assim, embora o pior cenário continue sendo não confessar enquanto o seu comparsa confessa, as perdas oriundas da opção preemptiva desse cenário, que é confessar, são tais, que o dilema é de resolução razoavelmente fácil para as partes envolvidas. Uma descrição mais apropriada para o dilema enfrentado por integrantes do cartel que ponderam uma eventual confissão, com a consequente defecção do cartel e cessação dos seus benefícios pode ser representada na tabela abaixo, que representa, não os anos de prisão previstos no dilema, mas sim a ordem de preferência por resultados de cada um dos prisioneiros: 
Tabela 4 - Tabela de ordem de preferência de resultados do Dilema do Prisioneiro aplicada ao direito antitruste. Fonte: elaboração própria a partir de (LESLIE, 2006)

\begin{tabular}{|l|rr|rc|}
\hline \multicolumn{1}{|c|}{ B } & \multicolumn{2}{|c|}{ Confessa } & \multicolumn{2}{c|}{ Não Confessa } \\
A & & 3 & & 4 \\
\hline Confessa & 3 & 2 & 2 & 1 \\
\hline Não Confessa & 4 & & 1 & \\
\hline
\end{tabular}

A versão estilizada do dilema do prisioneiro não dá margem, ou mesmo veda, que os prisioneiros adotem estratégias tendentes a reforçar a hipótese de um cenário cooperativo entre si.

A realidade, obviamente, é mais nuançada. As opções de reforço da cooperação em um ambiente de ilicitude são, essencialmente, o uso da violência, suave ou áspera, ou a construção de confiança.

Aplicações suaves de violência são comumente identificadas em investigações de cartéis, como no caso dos auditores já mencionados. Expressões mais violentas são raras, embora existentes, como ocorrido no âmbito do Processo Administrativo $\mathrm{n}^{\circ}$ 08012.001003/2000-41, que investigou a prática de cartel por postos de combustíveis localizados na cidade de Londrina/PR, no bojo do qual se identificou a existência de cinco líderes do cartel que se utilizavam, inclusive, de ameaças de morte voltadas a intimidar e influenciar os outros postos a participarem do ilícito (CADE, 2013a). No caso de outros tipos de organizações criminais, são inclusive bastante conhecidas (LYNCH e PHILLIPS, 1974).

Contudo, é interessante notar que o elemento confiança é prevalente. É conhecida, pelo Cade, por meio de provas documentais, como a confiança é importante como elo mantenedor do ilícito, fato soberbamente demonstrado no já 
citado "cartel das britas" (CADE 2005). De forma semelhante, em caso envolvendo o mercado de prestação de serviços de manutenção e calibração de instrumentos de medição na região de São José dos Campos/SP, investigado no âmbito do Processo Administrativo $\mathrm{n}^{\mathrm{o}}$ 08012.007356/2010-27, as empresas representadas chegaram a afirmar à Superintendência-Geral do Cade, como tese de defesa, a existência de um simples acordo de cavalheiros, e não propriamente um cartel, ao argumento de que esse "acordo" impediria o nivelamento por baixo dos preços do mercado (CADE, 2013b).

Leslie (2006, p. 462) refere vários estudos de teoria dos jogos que apontam na direção de que esquemas cooperativos são mais prováveis quando as interações são repetidas a longo prazo (situação comum em cartéis) e que o dilema do prisioneiro, em suas versões mais rudimentares, coloca demasiada ênfase no elemento racional. Fehr e Fischbacher (2003) chegam a apontar tendências evolucionárias influenciando a adoção prioritária, por indivíduos, de estratégias cooperativas, mesmo diante da necessidade de assunção de riscos e posições de vulnerabilidade.

Para Leslie (2006, p. 463), conquanto a adoção da estratégia superior, do ponto de vista do infrator, requer que ambas as partes adotem comportamento (não confessar) que em última análise as põe em posição de vulnerabilidade em relação à outra - que pode confessar e criar o pior cenário do jogo -, a construção da confiança é requisito necessário para a própria instalação e manutenção do cartel, daí que, em regra, as condições para a cooperação entre os infratores já estão presentes, tornando a preferência pela não confissão uma proposição menos arriscada, especialmente em cartéis estáveis.

Obviamente, os lucros obtidos com o esquema criminoso representam um importante cimento para este edifício. Isso torna a tarefa dos investigadores ainda mais complexa, pois, para evitar que o dilema do prisioneiro seja solucionado pelos infratores no sentido de não confessar, Leslie (2006, p. 465) propõe ser necessário: (i) tornar a opção por confessar dominante, ou seja, confessar é a melhor opção para determinada parte independentemente da opção adotada por seu comparsa; (ii) impossível a última hipótese, aumentar a atratividade da opção confessar; (iii) dificultar a construção de confiança entre os membros do cartel. 
A situação muda substancialmente quando a autoridade já detém informações sólidas sobre a existência da infração, seja por meios de investigação independentes, seja pela colaboração de um participante do cartel. Quando o ambiente de sigilo necessário à consumação da infração é rompido, os benefícios advindos da sua prática cessam e permanece apenas a probabilidade, cada vez maior, de arcar com os pesados custos advindos da punição (LEVENSTEIN e SUSLOW, 2010, p. 13-18).

A estratégia de confessar, após a detecção da infração de maneira convincente, torna-se dominante, nos termos da matriz que segue:

Tabela 5 - Tabela de ordem de preferência de resultados do Dilema do Prisioneiro aplicada ao direito antitruste. Fonte: elaboração própria a partir de (LESLIE, 2006)

\begin{tabular}{|l|l|l|l|l|l|c|}
\hline $\begin{array}{l}\text { Cartel com } \\
\text { "X" números } \\
\text { de membros }\end{array}$ & $\begin{array}{l}\text { Se } \\
\text { ninguém } \\
\text { confessou }\end{array}$ & $\begin{array}{l}\text { Se 1 } \\
\text { participante } \\
\text { confessou }\end{array}$ & $\begin{array}{l}\text { Se 2 } \\
\text { participantes } \\
\text { confessaram }\end{array}$ & $\begin{array}{l}\text { Se 3 } \\
\text { participantes } \\
\text { confessaram }\end{array}$ & $\ldots$ & $\begin{array}{l}\text { Se x-1 } \\
\text { participantes } \\
\text { confessaram }\end{array}$ \\
\hline Confessa & 2 & 1 & 1 & 1 & $\ldots$ & 1 \\
\hline Não confessa & 1 & 2 & 2 & 2 & $\ldots$ & \\
\hline
\end{tabular}

A inversão da estrutura de incentivos, nos casos apresentados, tem apreciável impacto na formulação de jogos e no entendimento do problema de modelagem de programas de leniência. O prévio conhecimento ou não da infração, e a eventual colaboração já existente em um mesmo caso, modifica o espaço estratégico dos jogadores e deve ser observado com atenção para definição das regras do jogo e na operacionalização de sua solução.

\subsection{Conclusões}

Como visto, a estrutura básica de incentivos para a confissão de um cartel é, a princípio, desfavorável à opção pela confissão - ao menos nos casos em que a autoridade investigadora não detém informações sobre a prática - considerados os 
custos suportados pelo agente que confessa e os benefícios fruíveis na opção pelo silêncio, versus os custos e benefícios associados à adoção da confissão.

A importância da demonstração matricial dos principais aspectos relacionados a um jogo que envolva a delação de um cartel é asseverar o quão tormentosa é a decisão para aqueles que, por qualquer razão, se encontrem em um jogo com características similares.

A afirmação da inversão de incentivos em casos em que a infração é conhecida, por sua vez, revela as vastas oportunidades que se oferecem a uma modelagem que pretenda obter confirmações e ampliações daquilo que já é conhecido, tirando proveito da atratividade crescente da opção confissão pelos demais jogadores.

Arranjos que busquem ampliar o número de confissões, particularmente em casos de completa ignorância dos fatos por parte do investigador, devem se direcionar, nesse cenário, a aumentar, sempre que possível, os custos da opção pelo silêncio e, ao mesmo tempo, mitigar os receios e sacrifícios decorrentes da adoção do caminho da colaboração, sobretudo por meio do oferecimento de garantias contra os seus efeitos negativos e benefícios tangíveis capazes de compensar, ou mitigar, as perdas suportadas.

Do mesmo modo, podem extrair benefícios da inversão de incentivos após a primeira confissão, estruturando-se para cooptar novos colaboradores em uma mesma investigação, escalonando as garantias e benefícios auferíveis, sem fomentar uma postura de passividade do tipo "pagar para ver".

A opção por um determinada estrutura normativa e prática de uma política estatal de incentivo à delação é, fundamentalmente, a escolha de um modelo de jogo, do tipo dilema do prisioneiro. É possível, a partir da correta atribuição de jogadores, estratégias e resultados, avaliar a sua consistência com a teoria dos jogos. Programas de leniência na esfera antitruste, conscientemente ou não, incorporam em si variadas características coerentes com os objetivos acima delineados. A observação de alguns destes programas pode indicar as principais e permitir a sua avaliação mais pormenorizada. 


\section{A inserção dos programas de leniência no antitruste}

A consideração dos danos resultantes da cartelização, associado à dificuldade de obtenção de provas deste tipo de infração, incentivou as autoridades antitruste a buscar formas criativas de quebrar o vínculo de segredo que é essencial a este tipo de prática. A partir de 1978, com a inserção do Programa de Leniência dos Estados Unidos da América, e sobretudo após 1993 quando este mesmo programa foi reformado, a adoção de políticas voltadas ao incremento de confissões obtidas em acordos de leniência tornou-se a principal ferramenta de combate a cartéis (KLOUB, 2009). O exemplo norte-americano influenciou diversas jurisdições, tendo dezenas de países adotado programas de leniência com características semelhantes (BURHART e HENRY, 2015; MELLO, 2015; VARNEY, 2014).

O presente capítulo fará uma descrição, em linhas gerais, do funcionamento dos programas de leniência americano, comunitário europeu e brasileiro, com descrição da seus principais requisitos, benefícios e normas de funcionamento, para, ao fim, selecionar os seus elementos identificadores comuns.

\subsection{O Programa de Leniência dos Estados Unidos da América}

O programa de leniência nos EUA possui como base legal o Sherman Antitrust Act de 1890, que define, na Seção 1 (Section 1), no que consiste a prática de cartel. O órgão responsável pela aplicação do programa é a Divisão Antitruste do Departamento de Justiça dos EUA, o qual pode celebrar acordos tanto com empresas, quanto com indivíduos. A Divisão criou o programa de leniência em 1978, tendo estabelecido a Política de Leniência para Corporações (Corporate Leniency Policy) em 1993 e a Política de Leniência para Indivíduos (Leniency Policy for Individuals) em 1994 (BARNETT e HAMMOND, 2008, p.01).

O Sherman Antitrust Act determina que qualquer contrato que possua indícios de conspiração para a restrição do comércio entre os estados americanos ou com as nações estrangeiras, deve ser considerado ilegal. Tal norma prevê também que é 
responsabilidade dos procuradores (government attorneys) e das cortes distritais investigar trustes e empresas que violarem a lei (GOVERNO DOS EUA, 1980).

Para a conduta ser considera uma violação a Section 1 do Sherman Act., podendo ser processada criminalmente, é necessário que contenha os seguintes elementos: 1) a existência de um acordo (explicito ou implícito); 2) ocorrer entre dois ou mais concorrentes; 3) restringir o comércio entre os Estados americanos ou com as nações estrangeiras (VARNEY, 2012, p.381).

Com o programa de leniência da Divisão de Antitruste, é possível que os agentes consigam imunidade contra a condenação penal e multas. No caso dos indivíduos, vale destacar que, dentre as sanções a serem evitadas na esfera penal, encontra-se também a pena de prisão. Para tanto é necessário que o candidato à leniência seja o primeiro a reportar a conduta e coopere plenamente com a Divisão, além de outras condições específicas (BARNETT e HAMMOND, 2008, p. 1).

O Procurador-Geral Adjunto para Aplicação de Caráter Penal da Divisão de Antitruste (The Division's Deputy Assistant Attorney General for Criminal Enforcement) é o responsável por rever todos os pedidos de leniência. Como a Divisão confere apenas uma leniência por conduta, as empresas que conspiraram entram em uma corrida pela leniência umas contra as outras, bem como contra seus próprios funcionários, que podem tentar a leniência individual. Nesse sentido, o tempo é essencial. Evidência disso é o fato de que, e também em várias ocasiões, a segunda empresa a solicitar leniência é desbancada pela primeira por uma questão de horas (BARNETT e HAMMOND, 2008, p.01-02).

Para dar mais chances aos candidatos, a Divisão criou um "sistema de senhas" (marker system), que segura à posição do primeiro requerente na fila para leniência, enquanto ele reúne mais informações para apoiar o seu pedido. O sistema segura as posições dos proponentes por um tempo limitado, mas, nesse interim, nenhuma outra requerente pode "ultrapassar" a que possui a "senha". A duração do tempo da "senha", por sua vez, varia de acordo com fatores como a localização e número de funcionários da empresa a serem entrevistados, a quantidade e a localização dos documentos a serem levantados, bem como se a Divisão já possui uma investigação 
em andamento no momento em que a "senha" é requisitada (BARNETT e HAMMOND, 2008, p.03-02).

Geralmente, um período de trinta dias de validação da senha é concedido aos casos em que a Divisão ainda não tenha iniciado uma investigação da conduta. $O$ período pode ser estendido, a critério da Divisão, se houver necessidade e se o candidato demonstrar esforço em cooperar e terminar a requisição em tempo hábil (BARNETT e HAMMOND, 2008, p.03-04).

Para adquirir a "senha" (marker) o advogado do requerente deve: 1) relatar que conseguiu obter informações que indiquem o envolvimento do seu cliente na conduta; 2) divulgar a natureza geral da conduta descoberta; 3) identificar a indústria, produto ou serviço afetado em termos específicos o suficiente para permitir que a Divisão determine se a leniência ainda está disponível e para proteger a "senha" do candidato; 4) identificar o cliente (BARNETT e HAMMOND, 2008, p.03-04).

A confirmação da violação da lei antitruste por parte da requerente não é necessária na fase do "sistema de senhas". Conduto, para obter a "senha", o advogado deve reportar que possui evidências que sugerem a possibilidade de violação antitruste, tais como, fixação de preços, licitação fraudulenta, restrição de capacidade e alocação de mercados, clientes, vendas ou volumes de produção. Às vezes, dependendo da indústria ou produto envolvido na conduta, apenas a identificação da indústria já é suficiente para a Divisão determinar a viabilidade da leniência. Isso acontece, por exemplo, no caso de não existir investigações pendentes sobre os produtos ou serviços da indústria em particular. Em outros casos, a identificação do produto ou serviço específico, ou a identificação da região ou dos consumidores ou dos concorrentes afetados podem ser necessárias para a Divisão determinar a viabilidade da leniência (BARNETT e HAMMOND, 2008, p.03-04).

Como as empresas sãs aconselhadas a procurar leniência na primeira indicação de irregularidades, o padrão de prova para a obtenção de uma "senha" é relativamente baixo. Isso se dá especialmente em situações em que a Divisão ainda não está investigando a conduta. Consequentemente, é mais difícil obter a "senha" quando a Divisão já tem posse de informações sobre a atividade ilegal (BARNETT e HAMMOND, 2008, p.03-04). 
O programa de leniência está disponível para as empresas antes ou depois de a Divisão iniciar a investigação. A leniência para as empresas segue dois tipos: Tipo A e Tipo B. O Tipo A está disponível somente antes de a divisão ter conhecimento da conduta, já a Tipo B é disponível mesmo depois de a autoridade já ter referido conhecimento (BARNETT e HAMMOND, 2008, p.04-06).

A leniência Tipo A é garantida de acordo com as seguintes condições: 1) quando a empresa solicitar a Leniência e a Divisão não tiver recebido nenhuma informação de nenhuma outra fonte sobre a conduta; 2) após a descoberta da atividade ilegal, a empresa ter agido efetivamente e prontamente para cessar sua participação na atividade; 3 ) a empresa reportar a irregularidade com sinceridade e cooperar contínua e plenamente com a Divisão durante a investigação; 4) a confissão de a prática anticoncorrencial ser um ato da corporação como um todo, e não um ato isolado de um ou mais funcionários; 5) a empresa se comprometer em indenizar as partes lesadas, quando possível; 6) a empresa não ter coagido outra a participar na atividade ilegal e claramente não ter sido a líder ou a autora da atividade ilícita (BARNETT e HAMMOND, 2008, p.04-06).

Se a empresa não cumprir com todas as condições expostas acima, é possível conseguir a leniência do Tipo B, se cumprir com as seguintes condições: 1) a empresa for a primeira a solicitar e se qualificar para a leniência em respeito à conduta; 2) se, quando a empresa buscar a leniência, a Divisão ainda não tiver evidências suficientes contra a empresa, que possam resultar em condenação desta última; 3) após a descoberta da atividade ilegal, a empresa tiver agido efetivamente e prontamente para cessar sua participação na atividade; 4) a empresa reportar a irregularidade com sinceridade e cooperar contínua e plenamente com a Divisão durante a investigação; 5) a confissão de a prática anticoncorrencial ser um ato da corporação como um todo, e não um ato isolado de um ou mais funcionários; 6) a empresa se comprometer em indenizar as partes lesadas, quando possível; 7) a Divisão considerar que a concessão da leniência não causará injustiças às outras partes, tendo em vista a natureza da conduta, o papel da empresa que confessa na conduta em questão, e quando a empresa procura a leniência (BARNETT e HAMMOND, 2008, p.04-06). 
Em ambos os tipos, a leniência é garantida somente à primeira empresa que se qualificar. Outros colaboradores, ainda que possam receber redução de multa, não têm garantia de imunidade no processo criminal. Por outro lado, há também o programa de Anistia Plus (Amnesty Plus), que pode ser utilizado por empresas que não conseguiram obter a leniência sobre uma conspiração A, que já estava sob investigação da Divisão, mas que ao realizar investigação própria, descobre uma conspiração B, de que a Divisão não tem ciência. Nesse caso, a empresa pode receber leniência para a conspiração $B$ e ter uma reconsideração pela Divisão no envolvimento na conspiração A. A discricionariedade da sentença é da Corte em que o caso está sendo investigado, mas a Divisão pode recomendar à Corte "descontos" na sentença referente à conspiração $\mathrm{A}$, devido à cooperação na descoberta da conspiração B (VARNEY, 2012, p. 392).

Em relação ao tipo de colaboração que é esperada por parte dos requerentes de leniência, o Modelo de Carta Condicional de Leniência para Corporações define como parte das obrigações da cooperação para a obtenção da leniência que a empresa proveja documentos, informações e materiais, não importando onde esses estejam localizados. A empresa também deve se esforçar para garantir a cooperação de seus funcionários em comunicar a conduta, bem como indenizar os prejudicados. (BARNETT e HAMMOND, 2008, p. 15-16).

A empresa requerente e seus funcionários não são obrigados apresentar documentos que foram produzidos dentro das políticas de sigilo profissional na relação advogado cliente ou de doutrina de produto de trabalho. Entretanto, a entrega voluntária dessas comunicações e documentos privilegiados é de certa forma incentivada, tendo em vista o entendimento comum entre os advogados de que essa entrega voluntária seria melhor para os interesses da empresa (BARNETT e HAMMOND, 2008, p. 15-16).

A respeito da confidencialidade, a política da Divisão Antitruste é de tratar todas as informações com confidencialidade, exceto quando o próprio candidato concorda em divulgar as informações, divulga-las de próprio cunho, ou quando há uma ordem de uma Corte para que a informação seja divulgada. Em geral as jurisdições têm adotado políticas semelhantes (VARNEY, 2012, p.394). A maioria 
dos candidatos também tem permitido troca de informações entre as jurisdições que estão investigando a conduta, para que estas últimas possam melhor coordenar as investigações. Tal medida é de certa forma benéfica para o requerente que, nesse contexto, não precisa responder a múltiplos pedidos de informação (VARNEY, 2012, p.392).

O processo de obtenção da leniência se encerra com a emissão de uma Carta de Leniência (Leniency Letter). Após a fase de pedido de "senha" e durante a investigação, é dada a empresa ou ao individuo uma Carta de Leniência Condicional (Conditional Leniency Letter). A Carta é inicialmente condicional porque a concessão da leniência final dependerá de quanto a empresa ou individuo tiver cooperado com a investigação, bem como conseguido cumprir com todas as exigências anteriormente mencionadas, que variam com o tipo de leniência (Tipo A e Tipo B). (BARNETT e HAMMOND, 2008, p. 23-26).

\subsection{O Programa de Leniência da União Europeia}

A Comissão Europeia, em parceria com as autoridades de concorrência dos estados membros da União Europeia, é a autoridade responsável pela aplicação das regras de concorrência da União Europeia (UE). No âmbito da Comissão Europeia, a Direção Geral da Concorrência é a entidade diretamente responsável pela aplicação das regras relacionadas à concorrência, ainda que as autoridades nacionais europeias também possuam competência para tratar de defesa da concorrência. $O$ programa de leniência europeu iniciou-se em 1996, sendo revisado em 2002 e 2006 (BURHART e HENRY, 2015, p. 117).

A Comissão possui amplos poderes de investigação e inspeção, incluindo a faculdade de demandar a produção de informações, recolher depoimentos de indivíduos, realizar buscas domiciliares e fechar instalações ou bases de negócios. O escopo legal da Comissão Europeia prevê ainda a aplicação de leniência para as empresas que apresentarem informações sobre carteis nos quais estiverem envolvidas. O enquadramento legal do Sistema de Leniência da União Europeia encontra-se previsto no documento chamado de Commission Notice on Immunity from Fines and 
Reduction of Fines in Cartel Cases ou Leniency Notice (COMISSÃO EUROPEIA, 2006).

A Comissão Europeia concede imunidade relativa a multas que de outra maneira seriam impostas à determinada empresa por razão de violação da legislação concorrencial. Nos termos da própria norma, o benefício em questão é concedido à empresa que (COMISSÃO EUROPEIA, 2006, item 8):

revele a sua participação num alegado cartel que afete a Comunidade, desde que essa empresa seja a primeira a fornecer informações e elementos de prova que, na opinião da Comissão, lhe permitam: (a) efetuar uma inspeção direcionada visando o alegado cartel; ou (b) determinar a existência de uma infracção ao artigo 1017 do Tratado sobre o Funcionamento da União Europeia (TFEU), relativamente ao alegado cartel.

Cabe destacar que apenas uma empresa pode se beneficiar da imunidade total. No processo de candidatura ao programa de leniência, a empresa proponente deve prover declarações e evidências relacionadas ao alegado cartel, especialmente indícios que datem do período da infração (BURHART e HENRY, 2015, p. 119).

No tocante às declarações fornecidas pelas empresas, estas podem ser apresentadas de forma escrita ou oral e devem incluir: a) uma descrição detalhada do cartel acordado; b) os dados de contato do candidato e dos outros membros do conluio; b) nomes, cargos e endereços dos indivíduos envolvidos no cartel e c) informações sobre outras autoridades de concorrência que tenham sido contatadas em relação ao cartel, ou autoridades que o proponente tenha considerado contatar (CHAPPATTE e WALTER, 2014, p. 104).

Além disso, para que a empresa seja considerada beneficiária da imunidade total, ela deve se comprometer a colaborar de maneira total, efetiva e de modo constante com a Comissão. Tal comprometimento abrange ainda a cessação da prática de cartel, de maneira imediata, logo após à candidatura ao programa de leniência. Essa condição, no entanto, pode ser revogada quando a Comissão avaliar que a continuidade da conduta é necessária para manter a integridade da investigação em curso (BURHART e HENRY, 2015, p. 124).

\footnotetext{
${ }^{7} \mathrm{O}$ artigo em questão refere-se a práticas anticompetitivas colusivas.
} 
Em hipótese alguma a empresa candidata ao programa de leniência pode destruir, falsificar ou ocultar evidências relativas ao cartel ou divulgar informações concernentes ao pedido de leniência, exceto, nesse último caso, para outras autoridades de concorrência (BURHART e HENRY, 2015, p. 119). Por fím, o proponente não pode ter sido a empresa a ter coagido outras companhias a participar do cartel. Neste caso, apenas poderá requerer uma redução da pena através da cooperação (BURHART e HENRY, 2015, p. 120).

A Comissão Europeia garantirá a imunidade à empresa que cumprir com os requisitos citados, no momento do pedido de leniência. Por outro lado, as companhias que não se qualificarem em todos os itens podem receber também reduções das multas. Nesse caso, as empresas devem agregar valor significativo às investigações em curso, como também suspender as atividades de cartel (BURHART e HENRY, 2015, p. 119).

Cumpre sublinhar que as empresas beneficiadas pela leniência não estão isentas das consequências na esfera civil pela infração cometida. Em outras palavras, tais empresas permanecem sujeitas às regras gerais de reparação civil dos danos causados pela violação às normas concorrenciais. Os demandantes de reparação por danos na esfera civil podem recorrer aos tribunais nacionais que possuem competência de julgar este pedido (BURHART e HENRY, 2015, p. 127).

No que tange ao aspecto procedimental, a admissibilidade ao programa de leniência da Comissão Europeia está sujeita à apresentação da empresa à Direção Geral da Concorrência. A companhia deve realizar, dessa forma, um pedido de senha à autoridade, que confirmará a sua disponibilidade. Nos casos em que uma outra empresa já tenha se apresentado para delação, a companhia poderá realizar uma solicitação formal de concessão de redução das multas (CHAPPATTE e WALTER, 2014, p. 105).

Nos termos da lei, a Comissão Europeia concede reduções de multas de três faixas distintas às companhias que se apresentem posteriormente para o processo de leniência: 

informações que possam agregar valor significativo às investigações.

(ii) De 20 a 30 por cento para a segunda empresa a apresentar tais informações;

(iii) De 0 a 20 por cento para as empresas subsequentes. (Comissão Europeia, 2006, item 26)

Serão levados em consideração, no momento da concessão das reduções de multas, o momento e a qualidade das informações apresentadas. Em sequência, a Comissão, seguindo o modelo americano, concederá uma senha ("mark") que resguardará a posição do candidato na fila do programa de leniência. Nos casos em que a companhia candidata à leniência falhe em fornecer as informações devidas, a sua candidatura será rejeitada, sendo possível, porém, uma nova aplicação posterior. Desse modo, nesse período, outra companhia tem a possibilidade de se apresentar como candidata à leniência e se beneficiar da imunidade (CHAPPATTE e WALTER, 2014, p. 105-106).

Em geral, as regras para a manutenção das senhas são estritamente observadas pela Comissão e a falha no provimento dos documentos devidos por parte das companhias requerentes de leniência implica na perda imediata da sua senha. Contudo, existem casos em que a Comissão pode proteger a posição do primeiro proponente. Um exemplo disso se dá nas circunstâncias em que um administrador tiver assumido recentemente uma empresa, necessitando de um prazo adicional para recolher as informações devidas para a condução das investigações (Comissão Europeia, 2006, p.5).

As informações e documentos apresentados à Comissão Europeia no escopo do programa de leniência, assim como a identidade do beneficiário, em regra, recebem tratamento confidencial até a conclusão das investigações. No entanto, a Comissão possui a faculdade de tornar pública as informações relativas à investigação da prática de cartel, bem como revelar informações sobre o envolvimento dos lenientes, após a emissão da decisão final referente ao caso (BURHART e HENRY, 2015, p. 127-128).

Da mesma forma, as autoridades de concorrência da União Europeia podem trocar entre si informações, ainda que confidenciais, para o propósito de aplicação da legislação concorrencial. De acordo com a Diretiva 2014/104 da Comissão Europeia, 
as declarações realizadas no âmbito do programa de leniência, bem como depoimentos e acordos submetidos no escopo da leniência são protegidos de divulgação em casos de ações privadas de danos. Isso se aplica mesmo aos documentos relativos à leniência, que estejam em posse de outras partes (COMISSÃO EUROPEIA, 2016).

Em conclusão, a Comissão Europeia oferece diversos incentivos para que empresas envolvidas em prática de cartel cooperem e se beneficiem do programa de leniência. Em contrapartida, espera-se que os candidatos à leniência forneçam prontamente à Comissão todas as informações e evidências consideradas relevantes que possuam ou a que tenham acesso.

A colaboração da empresa como leniente requer a entrega de documentos relativos ao cartel que descrevam detalhadamente a sua participação e dos demais envolvidos na conduta. Espera-se que entre os documentos constem a data específica de duração da prática, o lucro gerado, segredos de negócios, entre outros dados que normalmente não seriam obtidos pela autoridade, senão por meio de acordo de leniência.

A empresa deve ainda permanecer à disposição da Comissão para responder a toda e qualquer requisição que possa contribuir com o devido estabelecimento dos fatos, assim como manter os seus funcionários e diretores disponíveis para as entrevistas que venham a ser levadas a cabo pela Comissão.

\subsection{O Programa de Leniência do Brasil}

Conforme disposto no capítulo VII da Lei 12.529 de 2011, o programa de leniência brasileiro dirige-se a qualquer pessoa física ou jurídica envolvida em infração à ordem econômica e requer cooperação integral com as autoridades de concorrência por parte da proponente do acordo, devendo a mesma identificar os demais participantes da conduta - sejam eles pessoas físicas ou jurídicas - e apresentar provas que evidenciem o conteúdo da delação. 
Ainda como requisito da celebração do programa de leniência junto ao Cade, o acordo deve ser firmado em circunstância na qual a Superintendência Geral daquela autarquia não disponha de provas suficientes para a condenação dos envolvidos no ilícito. Caso contrário, se a Superintendência Geral estiver ciência da prática anticompetitiva no momento da proposta de um acordo de leniência, cabe ao Cade a decisão de reduzir a penalidade administrativa aplicável entre um e dois terços do valor total, conforme a presença de circunstâncias atenuantes ou fatores agravantes. Ademais, cumpre observar os requisitos enumerados no capítulo VII da lei da concorrência, quais sejam, i) ser o proponente do acordo o primeiro envolvido no esquema a delatar a conduta anticompetitiva, ii) confessar sua participação na infração, cooperando integralmente com as investigações e o processo administrativo, e iii) cessar completamente a sua participação na infração em questão (CADE, 2016b, p. 9).

Em contrapartida, o acordo de leniência brasileiro prevê a imunidade administrativa e penal da parte signatária e, conforme mencionado no parágrafo único do capítulo VII da lei 12.529 de 2011, extingue automaticamente a punibilidade dos crimes contra a ordem econômica nestas searas, desde que efetivamente cumpridos os requisitos e obrigações previstos no programa de leniência. O programa de leniência brasileiro não confere imunidade na esfera cível, podendo os signatários de acordos de leniência ser processados por danos causados a terceiros (CADE, 2016b, p. 17-18).

Para além da leniência convencional, proponentes interessados na imunidade administrativa e penal, referente a condutas colusivas praticadas, também podem firmar a chamada Leniência Plus. Seguindo as mesmas etapas da leniência convencional, a Leniência Plus é caracterizada pela delação de uma segunda conduta anticompetitiva sobre a qual as autoridades do Cade não têm conhecimento. A delação desta segunda prática anticoncorrencial permite ao proponente obter imunidade administrativa e penal naquela conduta, além de reduzir em um terço a penalidade aplicável na conduta original, onde não havia a possibilidade de se obter acordo de leniência (CADE, 2016b, p. 53-57).

Estabelecidas as condições e contrapartidas do programa de leniência, cabe ainda explicitar a dinâmica relativa aos benefícios diferenciados conforme a ordem 
cronológica das delações. O programa de leniência brasileiro é caracterizado por três fases, a saber, i) o pedido de senha (marker), ii) a apresentação de evidências da infração à ordem econômica e iii) a formalização do acordo de leniência (CADE, 2016b, p. 24).

A fase do pedido de senha, ou marker, refere-se à comunicação de determinada conduta anticompetitiva à Superintendência Geral do Cade, feita por parte do proponente da leniência. Para realizar-se o pedido de senha, deve ser submetida proposta inicial de leniência ao Cade, explicitando a identidade dos agentes envolvidos na conduta, os produtos ou serviços e a área geográfica afetada, além da duração da prática colusiva. Em contrapartida, a primeira proponente de um acordo recebe um "Termo de Marker", isto é, uma declaração do Cade atestando a presença dos requisitos para a assinatura de um acordo e providenciando as diligências necessárias para o prosseguimento do programa de leniência (CADE, 2016b, p. 2527).

Caso algum proponente já tenha informado ao Cade determinada conduta anticompetitiva com vistas à leniência, os demais interessados em firmar um acordo são classificados conforme a ordem cronológica da proposta efetuada ao órgão antitruste, permanecendo aberta a possibilidade de um acordo pleno em caso de desistência dos primeiros delatores da 'fila' e oferecendo ao Cade possibilidade de rejeitar eventuais propostas consideradas insuficientes de acordo com os termos do acordo de leniência (CADE, 2016b, p. 27).

Ademais, convém memorar a existência dos chamados Termos de Cessação de Conduta, que oferecem um incentivo subsidiário aos delatores retardatários, conferindo benefícios no âmbito administrativo, embora não alterem a seara criminal. Por meio deste outro instrumento legal, firma-se contribuição pecuniária a ser recolhida pelo colaborador seguindo o mesmo princípio cronológico do acordo de leniência. Conforme apresentado no Guia de Leniência do Cade, depois da instauração de procedimento administrativo e antes de o processo ser remetido ao Tribunal do Cade, a contribuição pecuniária deverá ser calculada com base na multa esperada, sobre a qual incidirá uma redução de $30 \%$ a $50 \%$ para o primeiro proponente de TCC; uma redução de $25 \%$ a $40 \%$ para o segundo proponente de TCC; uma redução de até 
25\% para os demais proponentes de TCC; e uma redução de até 15\% após a remessa dos autos ao Tribunal da autarquia (CADE, 2016b, p. 20-21).

Em seguida, procede-se à fase de negociação, em que o proponente fornece informações detalhadas ao Cade acerca dos pontos levantados na proposta inicial de leniência, bem como os documentos que comprovem tais informações. Dentre os documentos recebidos pela Superintendência Geral do Cade, destacam-se trocas de emails entre concorrentes, trocas de e-mails entre pessoas da mesma empresa relatando ajuste entre concorrentes, troca de correspondência entre concorrentes, mensagens de texto ou de voz eletrônicas, anotações, gravações e tabelas ou planilhas, comprovantes de reuniões, extratos telefônicos, cartões de visita ou mesmo editais e atas de julgamento de certames, entre outros (CADE, 2016b, p. 30-33).

Após a reunião dos documentos necessários e a análise favorável da Superintendência Geral, inicia-se a última fase do programa de leniência, que consiste na formalização do acordo de leniência (CADE, 2016b, p. 39-47).

No que tange à publicidade da informação, o programa de leniência brasileiro prevê o acesso restrito tanto à identidade dos signatários de um eventual acordo como aos documentos comercialmente sensíveis dos mesmos. O acesso aos documentos relativos ao acordo de leniência pode ser concedido aos investigados para fins de defesa no processo administrativo do acordo de leniência, sendo vedada, entretanto, a divulgação do acordo de leniência e de seus anexos, sob pena de responsabilização administrativa, civil e penal dos responsáveis. Em geral, a identidade dos signatários da leniência e informações essenciais para o desfecho do caso são tornadas públicas no julgamento do processo administrativo, no momento da divulgação do voto público do Conselheiro Relator (Artigo 207, $\S 2^{\circ}$ item II, do Regimento Interno do CADE).

Tomando por base a experiência do Cade, tanto em acordos de leniência quanto em acordos de cessação de conduta, prevalece a confidencialidade das informações prestadas, embora existam exceções à regra. A primeira destas exceções compreende os chamados termos de renúncia, que explicitam a permissão dos proponentes ou signatários do acordo autorizando o compartilhamento de informações com autoridades de outras jurisdições. A segunda exceção diz respeito a decisões 
judiciais. O Cade tem o dever de prestar informações - inclusive o que for relacionado a acordos de leniência - em caso de ordem judicial, que pode estar relacionada a ações de reparação de danos movidas por terceiros (CADE, 2016b, p. 52).

O processo de leniência se encerra com a homologação definitiva do acordo pelo Cade no momento do julgamento do processo administrativo. Embora a imunidade seja conferida desde a assinatura do Acordo de Leniência, ainda no início das investigações, o julgamento do processo ocorre, frequentemente, muitos anos depois (CADE, 2016a).

\subsection{Conclusões}

A avaliação integrada dos programas acima descritos demonstra com clareza a similitude entre eles. Com efeito, a convergência entre programas de leniência é bem vista e estimulada, de forma a promover uma ação integrada contra cartéis internacionais (KLOUB, 2010, p. 21).

O fato é que a mecânica é muito parecida e dela podem ser extraídas algumas características elementares. Todos os programas compartilham algumas preocupações centradas nos seguintes itens: (a) previsibilidade quanto aos requisitos, procedimentos e benefícios esperados; (b) existência de determinados graus de sigilo das negociações e das informações trocadas; (c) estabelecimento de incentivos para uma corrida para a confissão; (d) técnicas de comprovação documental da narrativa do delator.

No próximo capítulo, essas características serão avaliadas, de acordo com o esquema de incentivos derivado da teoria dos jogos, descrito no capítulo anterior. O programa de leniência brasileiro, por ser mais próximo à experiência do autor e dos potenciais leitores, servirá como referência principal.

\section{Avaliando os elementos centrais de um programa de leniência}

As características essenciais identificadas no capítulo anterior compõem um quadro de referência mínimo para a aferição de um programa de leniência. A 
existência de regras com viés voltado ao incremento da previsibilidade, sigilo, corrida pela delação e documentação da narrativa, é condição necessária para o bom funcionamento de uma política dessa natureza e, como será demonstrado, podem ser avaliadas à luz da teoria dos jogos.

O presente capítulo contém seções específicas para cada um desses atributos. A análise que se procederá é no sentido de descrever os impactos que a adoção de tal ou qual orientação tem no conjunto de incentivos que informam o jogo da delação, já descrito. As peculiaridades de cada item serão ponderadas na medida em que se aproximam ou se distanciam do resultado confissão, desejado pelo formulador da política.

As premissas de análise adotadas, por sua vez, informam que o conjunto de incentivos para a delação, em casos em que a autoridade não tem conhecimento da infração, está, a priori, direcionado à não confissão, considerados os custos associados às perdas decorrentes do abandono do esquema criminoso e às incertezas próprias ao longo e penoso processo de cooperação com os investigadores. Desta forma, em casos como esse, é imperioso que um bom programa de leniência esteja acompanhando de um ambiente que maximize os danos e incertezas da opção pelo silêncio e provenha estabilidade aos jurisdicionados que optam por dele participar.

\subsection{Previsibilidade}

Como já exposto, o modelo básico de um jogo voltado à confissão de um cartel esbarra nos expressivos ganhos advindos da permanência no conluio, que podem não ser compensados pelas prerrogativas concedidas ao delator. O primeiro passo de um programa que lida com essas variáveis, portanto, é ser claro - e generoso - quanto ao que oferece e seguro quanto ao efetivo gozo dos benefícios.

Com efeito, o privilégio da autoridade é desenhar as regras do jogo e, nesta posição, deve fazê-lo tendo em mente o cálculo das opções estratégicas dos potenciais delatores. Estes, de seu lado, enfrentam sempre o dilema de pesar os custos e benefícios de cada um dos caminhos que lhe são factíveis. 
Ainda que pareça prosaico, é essencial, para que o jogador possa ponderar adequadamente suas estratégias, que os benefícios decorrentes da delação sejam conhecidos da forma mais exata e com a maior antecedência possível. De outro modo, o viés pró silêncio pode ser insuperável, pois os ganhos do ingresso no cartel são conhecidos e auferidos no dia-a-dia e, portanto, precisam ser contrabalançados com algo tangível.

Pela mesma razão, o conhecimento prévio dos ganhos advindos da cooperação pode ser incrementado sobremaneira com o estabelecimento da certeza, ou automatização, da sua fruição, caso o delator se adapte às regras do programa. Naturalmente, a comparação entre ganho real de permanência no cartel versus ganho hipotético de confissão é inferior à comparação entre ganho real de permanência no cartel e ganho real de aderência à confissão.

\subsubsection{O gozo do benefício prometido deve ser certo}

A incerteza quanto ao efetivo desfrute das vantagens oferecidas é apontada como um fator determinante para o passo lento que o programa de leniência norteamericano seguiu entre o ano de sua criação, 1978, e sua reformulação em 1993 (KOBAYASHI, 2001, p. 2-3). Nesse primeiro período, as autoridades do DoJ, recebiam, em média, uma aplicação para leniência por ano. Após a reformulação, tais números passaram a ser de uma por mês (MOTCHENKOVA, 2004, p. 2).

Uma das reformulações mais significativas operadas em 1993 - considerada causa essencial do sucesso dos anos posteriores - foi a mudança de paradigma sobre a expectativa de gozo dos benefícios da delação. Até então, o grau de imunidade oferecido variava de acordo com a discrição do procurador responsável pelo caso e somente era conhecido após um balanço feito ao fim da colaboração (HAMMOND, 2000). O potencial delator, desta forma, embora conhecesse as regras do programa e a existência de vantagens na adesão, não sabia com exatidão quais os seus termos finais.

Após 1993, convencionou-se que, uma vez que o delator se adequasse às regras do programa, a concessão de imunidade total pelas práticas ilícitas confessadas 
era automática, independente, portanto, de ponderação pelos órgãos acusadores (SPRATLING, 1998). Nesse ambiente, a atratividade da confissão tornou-se maior, uma vez que o aderente em potencial podia comparar com mais clareza as opções disponíveis, tornando-se, assim, a princípio, menos refratário à cooperação e, por consequência, menos suscetível ao viés pró silêncio que é condição estrutural deste tipo de jogo.

O programa de leniência do Cade, que surge em momento posterior à reforma do programa norte-americano, já incorpora, desde o início, a automatização da concessão da imunidade. Ainda assim, o legislador brasileiro não deixou de proceder a alterações que reforçassem este ponto.

Veja-se, a propósito, a proibição vigente, nos EUA, de se firmar um acordo de leniência com o líder do cartel. Para Leslie (2006, pp. 478-481), a exigência é contraproducente, entre outras razões, por diminuir a previsibilidade do programa em relação a todos os participantes, uma vez que a definição ex ante do que seria exatamente o exercício de liderança é complexa e pode suscitar dúvidas sobre a elegibilidade para o recebimento do benefício tanto no potencial delator quanto na autoridade.

$\mathrm{O}$ autor afirma que a melhor maneira de contrabalançar a influência do líder do cartel é assinalar penas maiores a estes infratores e oferecer também o benefício da imunidade, pois, além de eliminar o efeito acima elencado, traria ainda o benefício adicional de tornar a sua essencial função no cartel ainda mais difícil de ser exercida, pois os demais comparsas saberiam que seus incentivos para confessar seriam ainda maiores. Bos e Wandschneider (2012) apresentam opinião mais nuançada, contudo contrária à exclusão na maioria das situações.

No Brasil, a introdução do acordo de leniência na legislação nacional através da Lei 10.149/2000 previu a impossibilidade de se conceder imunidade ao líder do cartel. A Lei 12.529/2011, contudo, eliminou esta exigência, tornando o programa de leniência brasileiro totalmente coerente com esta recomendação. É importante ressaltar que o Cade tem o padrão de assinalar penas mais severas às partes que exerceram função de liderança ou proeminência no cartel, como nos já citados casos do "cartel das britas" (CADE, 2005) e no "cartel do cimento" (CADE, 2014). 
Como um exemplo contrário, pode ser analisada a lei de delações premiadas brasileira. De acordo com seu art. $4^{\circ}$, ao investigado que colaborar, o juiz poderá conceder o perdão judicial, reduzir em até $2 / 3$ (dois terços) a pena privativa de liberdade ou substituí-la por restritiva de direitos daquele que tenha colaborado efetiva e voluntariamente com a investigação.

Não há uma parametrização exata sobre em que hipóteses será concedido o perdão judicial completo, por exemplo. A calibração dos benefícios, ao contrário, está jungida à personalidade do colaborador, à natureza, às circunstâncias, à gravidade, à repercussão social do fato criminoso e à eficácia da colaboração $\left(\S 1^{\circ}\right.$, art. $\left.4^{\circ}\right)$. De acordo como o $\S 4^{\circ}$ do mesmo artigo, o Ministério Público poderá deixar de oferecer denúncia se o delator for o primeiro a cooperar, ou seja, mesmo o prêmio máximo não é uma certeza.

Em que pese seja louvável a clareza quanto a existência do programa e dos benefícios dele auferíveis, a linguagem condicional relativa ao que será concedido - e em que circunstâncias - pode funcionar como um inibidor de novas delações, especialmente nos casos onde a autoridade não tem conhecimento sobre a prática e está, desta forma, em posição de vulnerabilidade em relação ao esquema criminoso.

Tome-se como exemplo a operação Lava-Jato, profusa em colaborações, mas que teve sua primeira delação oriunda de réu que já se encontrava preso preventivamente pela prática dos crimes que delatou. $\mathrm{O}$ programa do Cade, ao contrário, tem, entre suas 54 leniências firmadas, 52 casos em que não havia investigação pendente sob o esquema delatado.

Dada a estrutura de incentivos, um conjunto de benefícios menos exato pode não ser decisivo na ponderação do potencial delator quando a autoridade já suspeita de sua participação em um determinado ilícito e devota recursos para esclarecê-lo. No entanto, como o exemplo do programa de leniência americano atesta, pode ser uma limitação expressiva aos objetivos da autoridade que o formula, quando se trata de atrair informantes de ilícitos até então desconhecidos.

Contudo, a importante tarefa de fornecer previsibilidade a um programa de leniência não se esvai na definição dos benefícios e na concessão de certo grau de 
certeza quanto à sua fruição. As regras sob as quais a delação se desenvolverá são igualmente importantes.

\subsubsection{O procedimento deve ser claro}

Imagine-se a situação de um delator em potencial que, conhecendo os benefícios da adesão ao programa e tentado a buscar a opção pela confissão, analisa

quais os próximos passos a seguir. É preciso que o delator ou, mais importante, seus advogados, tenham a capacidade de delimitar, da melhor maneira possível, todo o percurso adiante, de maneira a mapear as variáveis chave do processo. O ponto essencial aqui - tal qual em relação aos benefícios esperados e à certeza do seu gozo é ampliar a compreensão sob a opção cooperar em um cenário em que o silencio é atrativo em si.

Indagações básicas sobre como disparar o processo de delação, quem procurar, qual a forma de conduta, as garantias de procedimento, tempo de duração da negociação do acordo, etc., podem representar uma barreira substancial à adesão a um programa de leniência. Há de se ter em mente que a decisão de procurar uma autoridade para confessar crimes, apontar seus companheiros de jornada delitiva e rejeitar o proveito econômico derivado da conduta reconhecida é, fundamentalmente, um rompimento severo com o status quo vivenciado pelo delator. Não é incomum que cartéis, por exemplo, se organizem por meio de ecossistemas sociais que transcendem o ambiente de negócios, tais como afinidades familiares, religiosas ou de vínculos de classe (LESLIE, 2004, p. 562-573), sendo o rompimento caracterizado pela delação muitas vezes extrapolado para a esfera psico individual mais elementar. A transição do terreno conhecido para o desconhecido deve, por conseguinte, do ponto de vista da autoridade que a quer facilitar, ser acompanhada, no mínimo, pela transparência no itinerário a ser percorrido.

A predefinição e publicidade de regras de convivência entre autoridade e investigado também é importante para que o foco do procedimento seja nas questões espinhosas relacionadas à elucidação da situação confessada. Observe-se que, no que concerne à duração de uma delação, a regulamentação do programa de leniência do 
Cade previa o prazo de seis meses, prorrogáveis por igual período, e foi suplantada por novo regramento que sequer prevê prazo, em virtude da exigência massiva de tempo para se aperfeiçoar uma confissão sólida. Durante todo esse período, são trocadas informações e experiências entre autoridade e investigado que, em si, tendem a requerer sobremaneira a atenção de ambas as partes envolvidas. Não é incomum que um processo de conformação de um acordo de leniência tome meses de negociação e resulte em um histórico na casa de dezenas de páginas de informações e documentos. Presumivelmente, não é interesse de nenhuma das partes que, iniciado o processo, sobrevenham querelas procedimentais a gerar tensões evitáveis.

Tome-se o exemplo do guia de leniência do Cade (CADE, 2016b), disponível no site da instituição, para amplo acesso por interessados. Trata-se de documento com 57 páginas, elaborado a partir do desenvolvimento de 91 perguntas hipotéticas, que poderiam ser feitas por profissionais com pouca ou significativa expertise no assunto, desde que interessados em conhecer as nuances do programa de leniência antitruste brasileiro. As indagações são sequenciadas para cobrir desde dúvidas sobre a natureza da leniência, procedimentos de negociação, fases do acordo até a convivência com a autoridade após a sua assinatura. Algumas perguntas sobre como se negocia um acordo de leniência, abaixo transcritas, ilustram o conteúdo nele veiculado:

29.O que é o pedido de senha (“marker”)?

30. Quem deve ser procurado na Superintendência-Geral do Cade para o pedido de senha?

31.O que deve ser reportado à Superintendência-Geral do Cade para o pedido de senha?

32.O pedido de senha deve estar acompanhado de documentos comprobatórios da infração noticiada?

O guia não tem força de lei nem vincula o comportamento do Cade (CADE, 2016b, p. 8), tal como ocorre com as normas sobre leniência presentes no regimento interno da autarquia. Não obstante, representa instrumento poderoso na propagação da atratividade do programa, pois cumpre com a função de minimizar as incertezas sobre as regras a serem observadas e o iter procedimental que o beneficiário da leniência cumprirá. Nesse sentido, se assemelha ao FAQ constante da página do Departamento 
de Justiça norte-americano sobre as práticas de leniência lá adotadas, que se apresenta na forma de perguntas e respostas direcionadas ao curioso, profissional experimentado ou não (DoJ, 2016).

\subsubsection{A autoridade deve ser confiável}

A trigésima pergunta do Guia de Leniência do Cade, acima transcrita (Quem deve ser procurado na Superintendência-Geral do Cade para o pedido de senha?), aponta para outro componente fulcral de uma ambiência previsível em um programa de leniência: a definição dos interlocutores do delator.

$\mathrm{O}$ ato de buscar a autoridade investigadora para confessar delitos praticados, mesmo que diante da convicção de que os benefícios prometidos serão alcançados, ainda assim é ato de profunda exposição por parte do criminoso, que fica vulnerável em relação àquele que é, em última instância, seu perseguidor e carrasco. A abstração através da institucionalização do procedimento, aqui, é insuficiente. É o elemento pessoal que prevalece. Ao declarar que busca a delação, ainda em sua fase inicial, o delator, pessoa física ou jurídica, sinaliza que cometeu o ilícito da área de competência da autoridade. Portanto, deve ter segurança de que aquele com quem dialoga tem consciência da singularidade da situação e está devidamente comprometido com as garantias inerentes ao processo em todas as suas fases.

Dentre estas, é fundamental a existência de uma porta de saída para o delator, acaso as negociações não prosperem. Ainda que as regras estejam definidas com clareza e as imunidades sejam franqueadas sem discricionariedade, o juízo sobre a adequação objetiva e subjetiva do proponente às regras do programa nunca será automático e dependerá de avaliação da autoridade. Por exemplo, no caso do programa de leniência brasileiro, deverá ser avaliado se o beneficiário efetivamente identificou os demais envolvidos na infração ou se os documentos e informações fornecidos são hábeis para demonstrar a existência do cartel (CADE, 2016b, p. 15).

Nesse cenário, inseguranças do delator sobre se é ou não elegível para o programa, que, frise-se, são inevitáveis em algum grau, podem ser fator inibidor 
considerável da decisão de cooperar. Inevitável a sua incidência, uma alternativa para mitigar os impactos negativos é garantir que, se por acaso ao fim da negociação não se chegar a um acordo entre as partes sobre a adequabilidade do delator ou utilidade da confissão, as informações trazidas durante o período de conversa entre as partes não serão utilizadas contra o delator tentativo.

É exatamente isso que faz o programa de leniência brasileiro, que prevê, na sua regulamentação infralegal (art. 205 do regimento interno do Cade), que a proposta do acordo em si não implica confissão, que a desistência é viável a qualquer tempo e que, se não houver acordo, os documentos serão devolvidos ao proponente sem a permanência de qualquer cópia em poder das autoridades, que, adicionalmente, não poderão utilizar as informações prestadas no âmbito da negociação para deflagrar investigação pelos mesmos fatos. Vale ressaltar que normas semelhantes existem tanto no programa norte-americano quanto no europeu (ICC, 2016).

A construção de uma relação de confiança, reforçada pelo regramento acima, é indispensável ao objetivo de criar condições favoráveis à opção pela cooperação. A definição de interlocutores ciosos das garantias fornecidas pelo programa, a clareza e certeza dos benefícios esperados, associada à previsão de porta de saída em caso de fracasso, se complementa com a segurança de que o acordo, uma vez entabulado e cumprido pelo beneficiário da leniência, será honrado pela autoridade.

Poucos eventos podem ser mais perniciosos à credibilidade de um programa de leniência do que o descumprimento, pela autoridade, das imunidades conferidas pela colaboração efetiva do beneficiário. A instabilidade daí derivada quase certamente faria pender a balança decisivamente pelo silêncio e tornaria o jogo elaborado pelo formulador do programa um exercício de futilidade, se considerada a premissa de que se deseja obter mais confissões.

No caso do programa de leniência brasileiro, o acordo é formalizado entre o beneficiário e a Superintendência-Geral, mas sua homologação definitiva ocorre apenas quando do julgamento definitivo do processo administrativo quanto aos demais acusados pelo Tribunal Administrativo de Defesa Econômico, órgão do Cade distinto da Superintendência-Geral e com autonomia decisória, que observará se o acordo se coaduna com as disposições legais aplicáveis e foi fielmente cumprido. 
Teoricamente, o tribunal do Cade poderia contradizer o acordo de leniência anteriormente firmado, muitas vezes anos antes. Não é o que ocorre na prática: de todos os acordos de leniência já apreciados pelo tribunal do Cade em sede de julgamento, nenhum foi rejeitado. Recentemente, um acordo de leniência foi homologado, mesmo tendo havido absolvição dos acusados na confissão (CADE, 2016c). Naturalmente, o fator essencial para esse resultado não pode ser atribuído exclusivamente a uma complacência do tribunal com os acordos firmados pela superintendência, mas certamente reflete, em algum grau, a cautela de ambos os órgãos para que o pacto seja honrado.

Uma dimensão interessante do programa de leniência brasileiro é que a prática de cartel é ilícito administrativo, cujo processamento é competência do Cade, e crime (art. $4^{\circ}$ da Lei 8.137/90), sendo responsável pela persecução penal o Ministério Público. O acordo de leniência, contudo, firmado perante o Cade, confere também imunidade criminal (art. 87 da Lei 12.529/2011) em relação à prática de cartel e crimes consectários.

A priori, o Ministério Público não participaria da celebração do acordo de leniência no âmbito do Cade e, não obstante, estaria vinculado a seus termos no seu múnus de órgão acusador na esfera criminal. Há quem defenda que a participação é de fato desnecessária (MARTINEZ, 2013, p. 268), como também há quem sustente que a não participação do parquet no acordo tornaria-o nulo de pleno no que se refere à imunidade penal (SALOMI, 2012, p. 215). Para além da disputa sobre qual interpretação é a mais adequada, o que merece trabalho próprio, é certo que se a parte responsável pela persecução penal - o Ministério Público - não reconhecer um benefício central à configuração do acordo de leniência e, nessa linha, denunciar ou mesmo investigar criminalmente um signatário pelos fatos confessados, a estrutura de incentivos que justifica a cooperação estará severamente prejudicada.

Cientes dos riscos desse cenário, o Cade e o Ministério Público tradicionalmente somaram esforços para que este último figurasse como signatário dos acordos de leniência antitruste, influenciado a sua elaboração e se vinculando aos compromissos assumidos pelo Estado como recompensa - ou leniência, melhor dizendo - pela cooperação do infrator. Mesmo que indefinida a precisão jurídica de 
uma ou outra doutrina, privilegia-se a segurança e previsibilidade que deve ser oferecia ao jurisdicionado que se busca atrair ao programa. Recentemente, as duas instituições firmaram memorando de entendimentos (CADE, 2016d) que, sem ter força de lei ou caráter vinculativo, aponta para a coordenação entre os principais atores envolvidos e distribui as atribuições de cada um deles.

Compara-se o exemplo acima com o que ocorre com o nascente programa de leniência no âmbito da lei anticorrupção, centralizado na Controladoria-Geral da União. Há quatro atores estatais que podem influenciar na percepção de benefícios associados ao programa - CGU, TCU, MPF e AGU - e alguns deles tem emitido declarações e mesmo normas (TCU, 2016) no sentido de definir unilateralmente seu papel no programa e impugnar a validade de eventuais acordos que não se coadunem com a participação percebida por cada um. É possível que esse fator seja determinante no fato que, embora haja diversas empresas investigadas na CGU por ilícitos dos quais já se dispõe de amplo conhecimento no âmbito da "Operação Lava Jato" - e nos quais, dessa forma, a estrutura de incentivos é fortemente inclinada à cooperação apenas um acordo de leniência tenha sido até o momento celebrado (CGU, 2016).

Contudo, inegável que outros fatores podem estar desempenhando uma influencia negativa na situação acima descrita. Um deles, provavelmente, é o imperativo do sigilo que, por ser tão essencial à modelagem de um programa de delação quanto a previsibilidade, será apreciado em tópico próprio.

\subsection{Sigilo}

O investigador que dialoga com um delator adquire inteligência sobre o funcionamento interno de uma organização que é sua responsabilidade última derrotar, através da ruptura de seu funcionamento e punição dos seus participantes. A percepção pelo adversário da investida pode ser fatal para o esforço empreendido.

Um cartel que toma conhecimento de apuração em curso, sobretudo uma que envolva o fornecimento direto de informações por um dos seus partícipes, terá todos os incentivos de se proteger através da destruição de provas e do reforço de laços entre 
os infratores acuados, dificultando o avanço das investigações. Por conseguinte, o sigilo é da natureza das tratativas conducentes a uma delação. Logo, a formatação de um programa de leniência passa pelo reforço do sigilo.

\subsubsection{O sigilo protege a investigação que se inicia}

Observe-se uma conduta comum do Cade após a assinatura de um acordo de leniência. Como regra, firmada a delação, a Superintendência-Geral do Cade prossegue a investigação por meio de um Inquérito Administrativo (art. 48, II, da Lei 12.529/2011), procedimento de caráter inquisitório, mais voltado à coleta de provas, e que pode ser revestido de sigilo (Art. 49 da Lei 12.529/2011). A razão é clara: reforçar a narrativa trazida à luz pelo delator, através da coleta de novas provas, explorando caminhos indicados na confissão (PEREIRA NETO e CASAGRANDE, p. 186-187). Nada mais razoável, nesse cenário, que não franquear aos demais investigados identificarem a situação em que se encontram, ao menos até este delicado momento.

Conforme frisado, sendo o cartel infração claramente ilegal, executada de forma coordenada e sob manto de sigilo pelos infratores, eventualmente a sua prova depende de um elemento de surpresa por parte da administração. Assim, em investigações de cartel, é comum o uso do sigilo. Estas, enfrentam um desafio especial, a saber: normalmente, a prova direta deste tipo de ilícito depende do acesso à dinâmica interna do cartel, o que pode ser feito através da delação de algum de seus participantes, interceptação de comunicações entre os membros do cartel, ou acesso às deliberações internas da organização, etc. (SANTOS, 2016, p. 64).

A delação - por meio de acordo de leniência ou outro meio - é evento que está, a priori, fora do alcance das autoridades de investigação, uma vez que é, por definição, disparada por um, ou mais de um, dos participantes do cartel. O acesso a dados da organização ilícita, por sua vez, por meio de interceptações telefônicas ou buscas e apreensões de documentos, tem de ser sopesado à luz das garantias constitucionais das pessoas físicas e jurídicas alvos de investigações (PEREIRA NETO e CASAGRANDE, p. 186-187). 
No caso de apurações conduzidas pelo Cade, de cunho exclusivamente administrativo, o uso de interceptações telefônicas, a priori, somente é permitido por meio do uso de prova emprestada de investigações criminais (MARTINEZ, 2013, p. 250-251). Assim, para efeito de prova direta do ilícito, afora a delação, disponível, para deflagração exclusiva pelo Cade, apenas a busca e apreensão, nos termos do art. 13, VI, d, da Lei 12.529/2011.

O pedido de busca e apreensão, em face das medidas que são tomadas para a sua execução, deve ser ponderado cuidadosamente, considerando os indícios disponíveis (PEREIRA NETO e CASAGRANDE, p. 186-187). A assinatura de um acordo de leniência, com identificação do delator e acompanhada de documentos, no entanto, caracteriza-se como forte indício a justificar a deflagração de uma operação de busca e apreensão com autorização judicial, como frequentemente ocorre ${ }^{8}$.

As ações de busca e apreensão ajuizadas pelo Cade, assim como as ações de busca e apreensão na esfera penal, tendem a ter a sua fase inicial, que inclui a distribuição, prolação da decisão liminar e cumprimento da medida, coberta pelo sigilo. Por consequência, este, que é um meio crucial de obtenção de provas diretas da infração que sejam externas à leniência, frequentemente depende, para seu triunfo, do segredo anteriormente garantido à confissão.

\subsubsection{O sigilo garante um ambiente favorável à negociação}

Além de contribuir para a proteção à investigação em seus estágios iniciais, o sigilo garante um ambiente favorável à condução das longas conversas e trocas de informação que levam à conformação final de um acordo de leniência. A natureza negocial do instituto não deve ser perdida aqui, vez que, efetivamente, cuida-se de barganha onde o delator abre mão de se defender - ou mesmo se autoincrimina quando não há imputação alguma -, provê informação sobre o ilícito em que se

\footnotetext{
${ }^{8}$ É o caso, por exemplo, da recente investigação sobre o suposto "Cartel do Silicato", investigado no Inquérito Administrativo $\mathrm{n}^{\circ}$. 08700.008985/2012, iniciado por Acordo de Leniência e seguido de Busca e Apreensão como, também, do chamado "Cartel dos Vigilantes", primeira investigação iniciada no Brasil através da assinatura de Acordo de Leniência (Processo Administrativo 08012.001826/2003-10), no ano de 2003 ou do chamado "Cartel da Laranja", processado no âmbito do Processo Administrativo 08012.008372/1999-14.
} 
envolveu e o Estado se abstém de aplicar a penalidade esperada cabível para o ato confessado (JEANROND, 2007).

Em um ambiente de negociação de um acordo, que inclui a reconstrução, de preferência documentada (CADE, 2016b, p. 32-33), de fatos passados, e no qual há engajamento de personagens, investigador e investigado, em certa medida antagônicos, a realização de repetidas rodadas de negociação ao longo do tempo é essencial para a escorreita construção de um acordo que reflita a complexidade inerente ao tema.

Daí que o tempo de duração da negociação de um acordo de leniência no Cade, por exemplo, se estenda por meses e as negociações, presenciais ou por telefone, sejam repetidas. As partes são instadas a documentar suas alegações, através de emails externos e internos, conversas por aplicativos de mensagens, planilhas, agendamento de reuniões, reservas de hotéis, etc. (CADE, 2016b, p. 32-33), preferencialmente com garantia técnica de fidedignidade das informações (CADE, 2016b, p. 34-35). As informações trazidas pelo delator podem ser consideradas insuficientes pela autoridade que, desta forma, requererá novas medidas aptas a sanar dúvidas ou, em última análise, rejeitará o acordo pretendido (CADE, 2016b, p. 34).

Veja-se que o sigilo da proposta de acordo de leniência perante o Cade, garantido explicitamente pela legislação (art. 86, § $9^{\circ}$, da Lei 12.529/2011), funciona como um colchão que permite que essa relação se desenvolva através do tempo com a tranquilidade necessária ao cumprimento da árdua tarefa que se apresenta aos dois lados.

Sem dúvida medida sensata. A construção de uma relação de confiança entre as partes envolvidas, como já assinalado, é pré-requisito para mitigar os pesados incentivos contrários à confissão que se apresentam ao potencial delator que pondera sobre a conveniência de utilizar a via da delação. O sigilo, assim como a garantia de uma porta de saída segura caso as negociações sobre o acordo fracassem, fortalece um programa de leniência na medida em que proporciona um ambiente favorável a que a autoridade investigadora invista tempo e recursos na definição das informações requeridas, na checagem de sua validade e na indução de comportamentos cooperativos do beneficiário da leniência que viabilizem um acordo robusto, tanto na 
amplitude dos fatos relatados quanto na segurança sobre a sua veracidade. Não menos importante, franqueia ao delator o tempo e a tranquilidade necessários ao bom cumprimento das missões que lhe serão designadas pela autoridade, além de prover certo conforto sobre os ricos associados ao insucesso das negociações. Para se ter uma ideia do esforço que envolve a construção de um acordo de leniência, basta mencionar que o Acordo de Leniência firmado no âmbito do Processo Administrativo 08700.002086/2015-14, tornado público por acordo entre as partes, soma setenta páginas de descrição dos fatos (CADE, 2016e).

\subsubsection{O sigilo suaviza os custos de entrada na negociação}

A situação do potencial delator, como já reiteradamente enfatizado, é particularmente frágil na equação examinada. A decisão de romper com o status quo advinda da opção pela confissão o põe, desde o primeiro momento, a mercê de uma série de intempéries que, se não abordadas adequadamente, podem ser decisivas para a não utilização dessa via (STEPHAN e NIKPAY, 2014, p. 16-19). A existência de regras voltadas ao sigilo do processo de delação desempenha uma função relevante no controle de algumas delas.

A assunção do papel de delator, seja por condicionantes culturais que repudiam a figura do alcaguete (MARTINEZ, 2013, p. 285), seja pela reprobabilidade dos atos confessados, tende a gerar custos substanciais, seja de ordem pessoal, para indivíduos, ou mesmo comercial, para empresas. A publicidade do envolvimento em atos ilícitos pode significar o fim de uma carreira para um executivo (LESLIE, 2006, P. 460) ou a execração, pública ou familiar9 ${ }^{9}$ Veja-se, a propósito, as declarações de Paulo Roberto Costa, notabilizado como um dos primeiros e mais relevantes delatores no âmbito da operação lava-jato, associando sua condição de preso confesso a de um portador de lepra ${ }^{10}$.

\footnotetext{
${ }^{9}$ A operação lava-jato tem oferecido inúmeros exemplos nesse sentido, inclusive com colabores tendo sido vaiados publicamente.

${ }^{10}$ Disponível em: http://www1.folha.uol.com.br/poder/2015/11/1703489-em-primeira-entrevista-aposdeixar-a-prisao-delator-diz-se-sentir-leproso.shtml
} 
Do mesmo modo, a reputação de uma empresa que se envolve em práticas criminosas pode ser severamente afetada, acarretando prejuízos às suas operações e sacrifícios consideráveis para a recuperação do prestígio perdido (STEPHAN e NIKPAY, 2014, p. 16). A empresa Siemens, por exemplo, tem, desde a década passada, expendido recursos da ordem de centenas de milhões de dólares com o propósito de cessar a conexão de sua marca com ilícitos e sinalizar à sociedade que não compactua com este tipo de prática e é vigorosa no sentido de preveni-las em seu funcionamento interno e na relação com o poder público e concorrentes (GILBERT e HUEY-BURNS, 2009). A cultura do compliance, recentemente desenvolvida em nível internacional e já introduzida no Brasil, é, em grande medida, baseada no pressuposto de se deve agir preventivamente para evitar os inúmeros danos decorrentes do envolvimento de uma empresa com comportamentos ilícitos.

O potencial de represálias por parte dos demais participantes, que são efetivamente traídos nos vínculos de confiança que sustentam a existência do círculo infrator, não deve ser subestimado. Ao expor-se como delator, pessoas físicas e jurídicas passam a uma relação adversarial com seus até então comparsas, que, por força dos próprios vínculos que geraram a infração em primeiro lugar, detém condições de atingir o delator de variadas formas, como, por exemplo, a sua exclusão de meios sociais comuns, a punição econômica no mercado comumente explorado ou, em última análise, a violência.

É importante ressaltar que uma confissão é o início, não o fim, de um processo que possivelmente resultará na condenação dos delatados. Contudo, após a assinatura do acordo, a condição de infrator do delator é certa por conta da confissão, ao passo que seus cúmplices ainda gozarão, ao menos por algum tempo, da condição de acusados e terão, por consequência, liberdade de manobra, mesmo que reduzida.

Diante desse cenário, é natural que o potencial delator tema a assunção, quase certa, dos custos, tangíveis e intangíveis, que decorrerão do reconhecimento explícito de que esteve em engajado em certo tipo de delito. Como dito, ainda que programas de leniência tenham na sua essência a mitigação ou eliminação de alguns desses custos, muitos são incontornáveis ou de apropriação limitada pela autoridade que oferece a leniência. 
O sigilo que se assegura à fase de negociação de um acordo de leniência se justifica como um inibidor de que as consequências acima mencionadas sejam sentidas de imediato. No entanto, em algum momento a autoridade deverá iniciar os procedimentos formais de acusação aos demais participantes da infração, situação na qual estes tomarão conhecimento das imputações que lhe são feitas e da existência de um delator. As regras de publicidade que se impõem, em certa medida, aos procedimentos tendentes à punição estatal, também indicam que à sociedade será dada algum tipo de satisfação sobre a existência do processo punitivo. O beneficiário da leniência, então, poderá estar sujeito aos mesmos prejuízos acima delineados.

\subsubsection{O sigilo evita que o colaborador esteja em inferioridade}

É consequência lógica que um processo baseado em uma confissão desaguará no conhecimento público da existência de uma delação e, em última análise, do nome do delator. Ainda que as regras sejam condicionadas ao controle do fluxo de informações, inclusive quanto ao nome dos colaboradores, as imposições de contraditório dos demais acusados e a publicidade dos atos processuais serão decisivas para o conhecimento, por infratores, vítimas e pelo público em geral, dos fatos em julgamento. Por consequência, beneficiários deverão, cedo ou tarde, enfrentar os custos decorrentes da opção pela confissão que não tenham sido completamente eliminados pela leniência conferida.

Naturalmente, tais custos tenderão a serem suportados, em maior grau, pelos demais infratores que eventualmente forem condenados e não se beneficiarem das garantias franqueadas ao colaborador. Contudo, como já salientado, enquanto não há condenação, os acusados ainda não são formalmente imputáveis, ao passo que o beneficiário da leniência já assumiu, oficialmente, a responsabilidade pelos atos que confessou. Está, portanto, desde o início, ao contrário dos demais, exposto a todas as consequências, jurídicas ou não, das condutas reportadas que não sejam abarcadas pela leniência.

Deve-se admitir que esse fator, em si, é inibidor da adoção pelo caminho da confissão. Aquele que pondera se deve ou não se engajar em um programa de delação 
obviamente considerará o grau de exposição a que estará se submetendo quando a sua identidade e os fatos narrados forem conhecidos por entes externos ao acordo (STEPHAN e NIKAY, 2014, p. 17). Um programa de leniência deve, por conseguinte, endereçar, de alguma forma, este receio. Como já discutido anteriormente, a estrutura de incentivos em uma delação por cartel, inclina-se no sentido de não colaborar, pois os ganhos decorrentes da permanência no conluio são efetivos ao passo que os benefícios da leniência intangíveis, ao menos em um juízo de prospecção.

Leslie nota que, ausente uma estrutura de incentivos fortemente favorável à delação, um fator que operará significativamente pela opção pela cooperação é o receio de ser o que se qualifica como "otário"11, ou seja, aquele que não confessa em um quadro em que a sua contraparte confessa e o expõe às severas consequências de ter sido traído (LESLIE, 2006, p. 462). A racionalidade dos jogadores indica que a percepção de que existe um risco efetivo de se tornar o "otário" induzirá à confissão. Em um jogo do tipo dilema do prisioneiro a mútua não confissão é Pareto eficiente, logo, mais atraente (CALLIARI, 2003, p. 53). A estratégia dominante, a mútua confissão, tende a ser deflagrada quando não há confiança entre os jogadores, que, temerosos de ocuparem a desagradável posição do "otário", optam por colaborar com a autoridade em troca dos benefícios oferecidos.

Programas de leniência, portanto, oferecem um conjunto de incentivos elevados àqueles que colaboram, ao mesmo tempo em que, por meio da maior probabilidade de condenação daqueles que são delatados, aumentam os riscos de estar na posição de "otário". No entanto, para que a proposição acima seja verdadeira, aquele que opta pela confissão, efetivamente, não deve suportar custos superiores àquele que não confessa. A estrutura de incentivos da delação estaria fundamentalmente comprometida se a posição de "otário" fosse assumida por quem coopera com a autoridade em troca das vantagens ofertadas. O nível de exposição incorrido pelo delator vis-à-vis os demais acusados, particularmente nas fases iniciais do processo, pode deflagrar situação análoga à referida.

No direito brasileiro, aquele que pratica cartel pode ser responsabilizado nas esferas administrativa, criminal e cível (SANTOS, 2016. P. 81-85). O acordo de

\footnotetext{
${ }^{11}$ Sucker no original em inglês.
} 
leniência oferece imunidade nas esferas penal e administrativa, mas não na cível, uma vez que esta busca a recomposição do patrimônio do particular prejudicado pelo cartel e o Estado não pode dispor deste direito, concedendo como vantagem a ser colhida em um acordo de leniência. A responsabilização cível é asseverada em processo movido por um particular prejudicado pelo cartel ou por ação coletiva provocada pelos legitimados em cada caso (SILVA E SOUZA, 2014, p. 40).

Ao fazer um acordo de leniência com o Cade, por conseguinte, o delator, ao contrário dos seus comparsas, em virtude da confissão, está desde o início mais exposto à responsabilização cível, pois não pode argumentar, por exemplo, em uma ação contra si movida, que as imputações são falsas.

Tome-se o exemplo do caso conhecido como "cartel do metrô", iniciado após acordo de leniência firmado entre o Cade e a empresa Siemens. No caso referido, o Estado de São Paulo, após tomar conhecimento da delação, alegando ser vítima do cartel confessado pela Siemens, imediatamente ajuizou contra esta - e apenas esta ação cível de reparação pelos danos oriundos dos fatos delatados (SILVA E SOUZA, 2014, p. 35-36). Como se percebe, a empresa que confessou foi desde logo penalizada pela conduta cooperativa e em uma situação não enfrentada pelos demais infratores.

A situação descrita, portanto, tem o potencial de desequilibrar a estrutura de incentivos de uma delação, tornando a opção pela cooperação pouco atrativa (LUZ e SPAGNOLO, 2016, p. 1). Um paliativo geralmente utilizado para evitar tais situações, é o sigilo sobre a identidade do delator para o público em geral nas fases iniciais da investigação, mesmo após assinatura do acordo de leniência. Esta postura pode ser verificada nos programas de leniência do Cade e da União Europeia (ANDRADE, 2015).

O Cade, por exemplo, tem consistentemente reiterado em todos os seus pronunciamentos, jurídicos ou públicos, que os termos do acordo de leniência e a identidade do signatário são sigilosos. O objetivo é preservar a confidencialidade do 
acordo de leniência, evitando a identificação do signatário. Os acordos de leniência, por sua vez, possuem disposições nesse sentido ${ }^{12}$.

A Lei $n^{\circ} .12 .529 / 2011$, em seu artigo $86, \S 9^{\circ}$, dispõe que a proposta de acordo de leniência será considerada sigilosa, salvo no interesse das investigações e do processo administrativo. O regimento interno do Cade, em seu art. 207, caput, $\S \S 1$ e $2^{\circ}$, estabelece as normas relativas à confidencialidade, sigilo e divulgação das informações constantes do acordo de leniência para o exercício do contraditório no processo, sendo detalhado no sentido de torná-las inacessíveis às partes que não integram o processo.

Coerentemente com o cenário acima desenhado, a previsão do caráter sigiloso da proposta de acordo de leniência é essencial para dar segurança aos possíveis interessados em denunciar um cartel e colaborar com as autoridades. O sigilo sobre a identidade do delator até o julgamento do processo administrativo, garantido pelas normas do programa de leniência do Cade, evita que o beneficiário da leniência seja colocado em situação mais gravosa do que os seus comparsas.

A união europeia, recentemente, expediu norma comunitária voltada ao estabelecimento de critérios para a publicidade de informações constantes de acordos de leniência. O regramento busca estabelecer níveis de sigilos de acordo com as fases de tramitação do processo, sempre mantendo a coerência com o objetivo de não agravar o nível de exposição do delator, quando comparado relativamente aos seus companheiros (COMISSÃO EUROPÉIA, 2014).

$\mathrm{Na}$ jurisdição americana, a indenização cível é calculada multiplicando-se por três o valor do dano causado pelo cartel ao prejudicado que busca compensação, os chamados treble damages. Uma fórmula encontrada para não desestimular eventuais delatores no direito americano foi garantir, a partir de reforma promovida em 2004, que o delator deveria recompensar apenas o dano causado, sem a obrigação de triplicá-los, garantindo uma diferenciação crucial em relação ao criminoso que não coopera. Andrade informa que referidas mudanças levaram a que fosse dobrado o número de delações recebidas pelo DoJ em casos em que não havia investigação

12 Veja-se, a propósito, modelo de acordo de leniência disponível em: 
antecedente e que representantes de empresas beneficiadas pelo novo modelo, em entrevistas, afirmaram que tal medida influenciou positivamente a decisão de optar pela confissão (ANDRADE, 2015, p. 121-122).

Em todos os casos acima mencionados reconhece-se a importância de se tentar evitar que a situação do delator seja fragilizada, do ponto de vista processual, relativamente aos demais conspiradores, tornando a opção por confessar mais atraente. O sigilo, nesse contexto, também é vetor para equalizar as posições das partes envolvidas.

\subsubsection{Conclusões}

A utilização do sigilo em um programa de leniência, portanto, é fundamental para garantir a ambiência necessária ao avanço das investigações, permitindo à autoridade penetrar nos segredos do círculo criminoso sem ser detectada. Também estimula a tranquilidade do potencial delator que considera aderir a um acordo de leniência, conferindo segurança ao procedimento de negociação e garantindo uma retirada eficaz em caso de fracasso do acordo. Além disso, estabelece as condições para que o longo processo de negociação que envolve a confecção de um acordo de leniência seja frutífero, consideradas as dificuldades enfrentadas por ambas as partes. Adicionalmente, auxilia na calibração de riscos assumidos pelo delator, impedindo que o nível de exposição enfrentando pelo colaborador seja desproporcional ao dos demais acusados.

Um dos principais efeitos positivos do sigilo em um acordo de leniência, contudo, especialmente em sua fase de negociação, é impedir que os demais participantes da infração tenham certeza sobre se há uma colaboração em curso, rompendo os vínculos de confiança que são essenciais à operacionalidade do esquema criminoso. O risco, permanente, de estar sendo traído por um dos seus comparsas, que pode estar negociando uma delação que nunca é informada ao público, pode ser fator decisivo na decisão pela cooperação (HARRINGTON, 2013), estimulando uma 
verdadeira corrida pela delação. Esta corrida pela delação, dada a sua centralidade a um programa de leniência, entretanto, será analisada em tópico próprio.

\subsection{Corrida pela delação}

Em uma situação de um programa de leniência voltado a detecção de cartéis, embora seja certo que a confissão se torna extremamente atraente, quase inevitável, se outra parte já confessou, a opção por não confessar, quando o cartel ainda não foi detectado e ninguém confessou, conforme analisado anteriormente, apresenta vantagens substanciais.

Leslie (2006, p. 467-473) postula que, ao contrário de um dilema do prisioneiro teórico, a tomada de decisão pelos participantes do conluio dá-se em um ambiente dinâmico, onde as partes podem avaliar o comportamento das outras. Com o oferecimento de recompensas significativas apenas ao primeiro agente que confessar, a autoridade dificulta a abordagem de esperar para ver o comportamento do comparsa. Harrington (2005) e Spagnolo (2005a) também chegam a conclusões semelhantes.

\subsubsection{O papel da preempção}

A hipótese de vir a ser descoberto pelas autoridades investigadoras pode não ser suficiente para atrair um membro de um cartel para a opção pela confissão, mas o receio de ser denunciado por um de seus companheiros sim. Um detonador poderoso de uma corrida pela delação é a confissão que ocorre por motivos puramente preemptivos $^{13}$, ou seja, a opção pela colaboração apenas para evitar que outro o faça primeiro lugar e subtraia a alternativa do seu universo de possibilidades (GÄRTNER, 2014, p. 5).

Conforme já explicitado, os vínculos de confiança são essenciais à operacionalidade de um cartel, em que há incentivos substanciais para que se tenha interesse na manutenção do esquema ilícito, crescentes à medida em que o conluio se 
fortalece e prospera no tempo. É de se esperar, portanto, que seja contra-intuitivo imaginar que determinado agente tenha receio de que um comparsa esteja prestes a confessar, de forma a deflagrar uma corrida. Leslie (2006, p. 472-473), contudo, aponta algumas razões para tanto.

Observe-se o caso do infrator que integra de mais de um cartel e vem a ter sua participação em um deles descoberta pelas autoridades. Nessa circunstância, em que já há uma desconfiança do investigador em relação ao comportamento do investigado, a atratividade pelo uso da leniência aumenta, ainda que os demais participantes não estejam envolvidos na primeira infração conhecida. Tome-se como exemplo o acordo de leniência firmado no âmbito de investigação de cartel em obras da Usina Nuclear de Angra 3 (CADE, 2015a). A beneficiária dessa leniência havia sido citada como copartícipe em cartel de fornecedores da Petrobras em outro acordo de leniência (CADE, 2015b). Após acusada, procurou as autoridades investigadoras e firmou um acordo de leniência em que informava da existência do outro cartel, do qual, inclusive, não fazia parte a sua denunciante original. Fez uso, assim, da ferramenta da leniência plus, disponível exatamente para explorar essa vulnerabilidade entre membros de cartéis.

Outra situação que pode deflagrar uma corrida pela delação é a suspeita de que algum dos membros do cartel, por razões internas, desistiu de participar do esquema ilícito. Parece ser o caso de leniências que são deflagradas quando um dos participantes é vendido para um comprador que não integrava o cartel anteriormente. Receosos que a nova administração discorde da conduta adotada e busque a leniência como forma de reduzir os custos associados à participação no ilícito, membros do cartel podem se sentir tentados a adotar uma confissão preemptiva (STEPHAN e NIPKAY, p. 15).

Participantes de um cartel também podem avaliar que um dos comparsas está de tal forma assustado com a possibilidade de descoberta, que esteja inclinado a confessar, ou, ainda, interpretar erroneamente os motivos dos demais e, com isso, decidir delatar. Spratling (1999, p. 3) cita caso em que mais de um integrante de um cartel procurou o DoJ no mesmo dia.

\footnotetext{
${ }^{13}$ À falta de uma palavra na língua portuguesa adequada, pois o termo prevenção é insuficiente para a descrição exata do fenômeno, opta-se por um neologismo.
} 
Como se percebe, a ideia de preempção permeia as relações de membros de um conluio criminoso que tenham a possibilidade de aderir a um programa de leniência. Cartéis, por sua vez, são reconhecidamente instáveis, podendo existir períodos em que o acordo se dissolve para restabelecer-se adiante (LEVENSTEIN e SUSLOW, p. 17). Leslie chega a referir que membros de cartéis enfrentam dois dilemas do prisioneiro: um voltado à decisão de trair o cartel no mercado, apresentando preços abaixo dos pactuados e desviando a demanda para si; outro voltado à questão sobre se delata ou não o cartel do qual faz parte (LESLIE, 2006, p. 477-478). Nesse cenário, programas de leniência devem ser voltados a explorar as dúvidas e instabilidades vivenciadas pelo infrator, de forma a tornar a opção pelo silêncio menos atraente e fomentar juízos favoráveis à preempção.

\subsubsection{Penas severas reforçam a corrida}

O modo encontrado por autoridades antitruste para influenciar as circunstâncias a favor da opção pela confissão é garantir benefícios significativos apenas ao primeiro que delatar o cartel, ao mesmo tempo em que se gera um ambiente rigoroso àqueles que são condenados pela prática. Isso passa tanto pela aplicação de multas severas às empresas infratoras, como pela persecução criminal dos indivíduos (SPRATLING, 1999).

A lógica subjacente consiste no reconhecimento de que todas as partes envolvidas sabem que os demais sabem que cada um pode obter diversas recompensas pela adesão ao programa de leniência. Isto torna cada um menos confiável aos olhos dos comparsas, criando um ciclo, vicioso ou virtuoso, a depender da perspectiva, de desconfiança. Se, ao mesmo tempo, existir a percepção de que a traição fará a parte que não confessa sofrer penas severas, então o receio de permanecer na estratégia de não confessar será ainda maior. Spagnolo (2004, p. 3-4) chega a propor que um programa de leniência realmente audacioso deveria premiar o delator com o valor das multas pagas pelos demais participantes do cartel, de forma a instilar um grau de desconfiança insuportável entre eles. 
No Brasil, os benefícios completos da leniência são acessíveis apenas à parte que seja a primeira a se qualificar com relação à infração denunciada e desde que a autoridade não tenha conhecimento da infração noticiada, sendo garantido um desconto substancial quando já há investigação em curso. As imunidades, contudo, atingem as esferas criminal e administrativa.

No que se refere aos custos de ser delatado, assim como ocorre com um participante de cartel nos Estados Unidos da América, o infrator submetido à jurisdição brasileira está sujeito a sanções criminais, previstas na Lei 8.137/90, a multas administrativas e proibições diversas de contratar com o Poder Público, previstas na Lei 12.529/2011, além de reparação civil por danos causados.

Martinez (2013, p. 222) apontava, em 2014, apenas 6 sentenças definitivas condenatórias pela prática de cartel, o que representa um número obviamente baixo. No entanto, este dado está sendo espetacularmente superado pela operação lava-jato, que, constantemente, apresenta executivos das maiores construtoras do país algemados e presos pela prática, dentre outros crimes, de cartel. A reparação cível, por sua vez, ainda está em fase embrionária no país, não se tendo notícia de sentença definitiva condenando e liquidando o valor da reparação, mas já há casos em que as partes chegaram a acordo sobre valores de indenização e a tendência é de crescimento do uso dessa via. As penas administrativas, por sua vez, são aplicadas com freqüência. Apenas em 2014, o Cade condenou 14 (catorze) cartéis, tendo a condenação do chamado "cartel do cimento" atingido valores de aproximadamente três bilhões de reais (CADE 2014b).

Dentro desse contexto, a calibração de incentivos da leniência vis-a-vis os riscos de ser delatado operam no sentido de reforçar o receio de um determinado participante de cartel se qualificar, no jogo da delação, como um "otário" se optar pelo silêncio. É notável a consistência dos números de acordos de leniência firmados pelo Brasil, descritos na tabela abaixo, especialmente quando se considera que a maioria esmagadora se refere a casos em que a autoridade não detinha conhecimento antecipado das infrações perpetradas: 
Gráfico 2 - Número de Acordos de Leniência firmados pelo (CADE, 2016a)

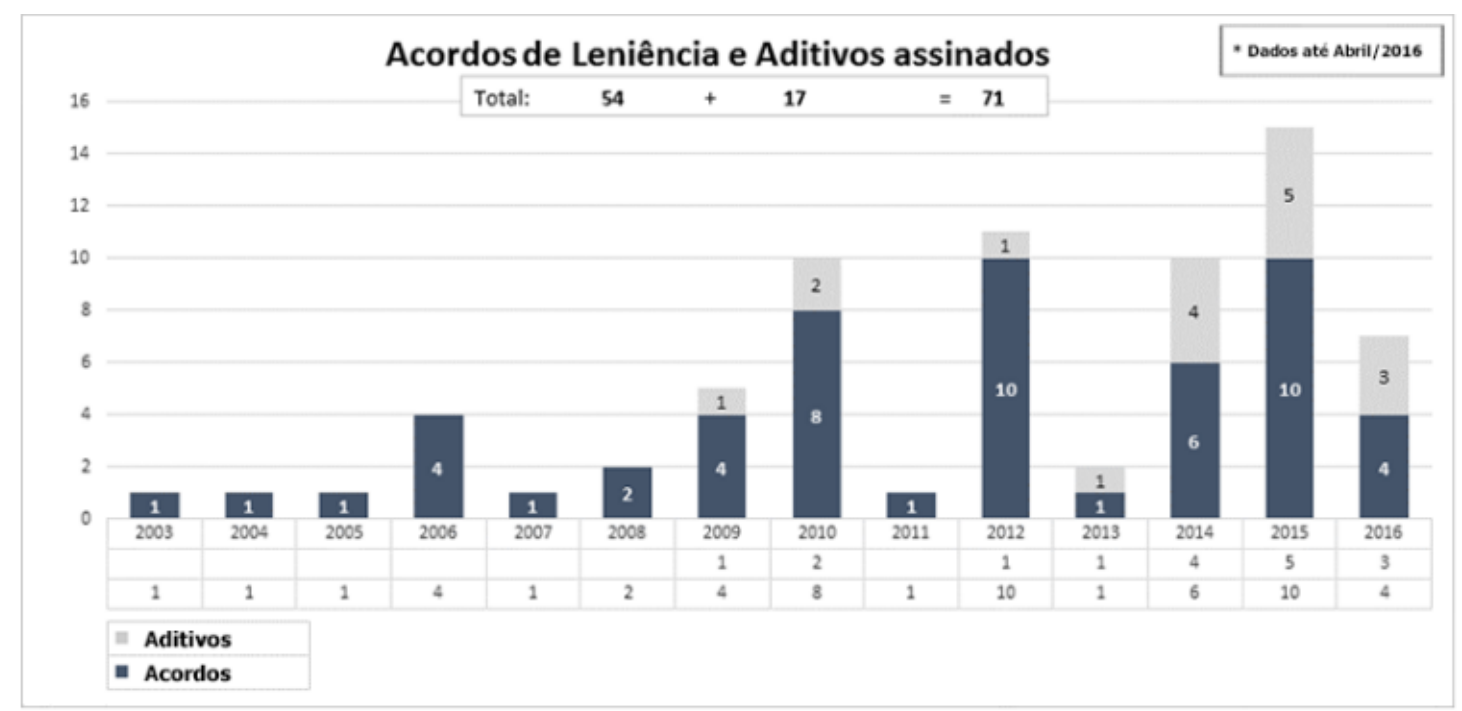

\subsubsection{O procedimento como um fomentador da corrida}

O programa de leniência do Cade, assim como o norte-americano e o europeu, é particularmente sensível no estabelecimento de regras voltadas ao incremento da corrida pela delação. O chamado sistema de "marker", por exemplo, é voltado a estimular o interesse de eventuais delatores por se anteciparem na busca de contato com a autoridade (CADE, 2016b, p. 25).

De acordo com a conformação do programa de leniência brasileiro, se uma parte deseja firmar um acordo de leniência com o Cade, deve procurar a Superintendência-geral do Cade, pessoalmente ou por telefone, e manifestar interesse em uma delação (CADE, 2016b, p. 25). Nessa ocasião, deverá informar, ainda que em termos gerais, sobre o cartel que pretende delatar, respondendo os quesitos "quem, "o que", "como" e "onde" nos termos abaixo (CADE, 2016b, p. 25-26):

31. O que deve ser reportado à Superintendência-Geral do Cade para o pedido de senha? 
Conforme o artigo $199, \S 1^{\circ}$ do RICADE, e independentemente de o pedido ser feito oralmente ou por escrito, o proponente deve apresentar as seguintes informações, ainda que parciais, acerca da infração noticiada:

I. “Quem?”: a qualificação completa do proponente do Acordo de Leniência, bem como a identidade dos outros autores conhecidos da infração denunciada. Em regra, portanto, não é possível verificar a disponibilidade da senha de forma anônima;

II. “O que?”: os produtos ou serviços afetados pela infração denunciada;

III. “Quando?”: a duração estimada da infração denunciada, quando possível;

IV. “Onde?”: a área geográfica afetada pela infração denunciada. Na hipótese de um cartel internacional, deve ser informado que a conduta tem o potencial de gerar efeitos no Brasil, nos termos do art. $2^{\circ}$, caput da Lei $n^{\circ} 12.529 / 2011$.

Importa destacar que a quantidade de informações necessárias para assegurar o pedido de senha pode variar conforme o caso, uma vez que haverá circunstâncias nas quais a SuperintendênciaGeral do Cade necessitará de mais ou menos informações para saber se a senha se encontra ou não disponível para a infração denunciada ou sob investigação.

A partir de então, a Superintendência-geral do Cade observará, internamente, se já dispõe de informações sobre o caso relatado - o que interferirá no conjunto de benefícios fruíveis pelo proponente - e se há acordo de leniência já firmado ou em fase de negociação para o mesmo caso. De posse dessas informações, será conferido à parte termo de "marker", descrevendo a infração noticiada e informando se o proponente se enquadra nos requisitos para propor um acordo de leniência. $\mathrm{O}$ termo de "marker" determina a posição na fila do potencial delator e assegura, se for o caso, que ele venceu, pelo menos a princípio, a corrida pela leniência. Diz-se a princípio, pois um termo de "marker" não garante a assinatura de um acordo de leniência, que, como explicado, requer demoradas negociações, que podem resultar na rejeição da proposta ou mesmo na sua desistência (CADE, 2016b, p. 25-30). A requisição de um termo de "marker" corre no mais absoluto sigilo, seguindo, em linhas gerais, o procedimento abaixo descrito (CADE, 2016b, p. 31):

I. o acesso à informação sobre o pedido de senha é restrito ao Superintendente-Geral, ao Superintendente Adjunto, ao Chefe de Gabinete da Superintendência-Geral e aos 
servidores da Chefia de Gabinete da SG/Cade, responsáveis pela condução da negociação do Acordo de Leniência;

II. os dados anotados no controle interno da Chefia de Gabinete da SG/Cade para a análise do pedido de senha são acessados apenas por servidores dessa unidade;

III. os documentos eventualmente apresentados para o pedido de senha são guardados em sala-cofre, que apenas são acessados por servidores da Chefia de Gabinete da SG/Cade;

IV. a apresentação e guarda dos documentos e/ou evidências para análise da SG/Cade poderá ser combinada caso a caso entre os proponentes e a SG/Cade; e

V. a comunicação com os proponentes do Acordo de Leniência é realizada, sobretudo, de modo oral.

Como se percebe, o sigilo aqui ocupa posição instrumental no fomento à corrida pela delação, garantindo que as partes não tenham ciência sobre se já estão sendo delatadas e, desta forma, instigando o temor que é o grande combustível da preempção que se deseja ver ocorrer. Ao mesmo tempo, a previsibilidade conferida pela outorga do termo também incentiva a busca pelo instrumento e, naturalmente, o receio de que outro cúmplice já tenha adotado o mesmo caminho.

É curioso, contudo, contemplar o fato de que o regulamento do programa de leniência brasileiro prevê que, existente uma negociação em curso para o mesmo cartel relatado, será certificado à parte proponente tal fato, atribuindo-lhe uma posição na fila pela delação, mas sem lhe informar exatamente qual (CADE, 2016b, p. 27-28). A importância do sequenciamento de uma fila, nesses casos, é que uma delação em curso pode não se materializar, ocasião em que o próximo ocupante da fila será chamado à negociar, ou, mais importante, caso aquela se materialize, a posição das partes na fila influenciará os benefícios esperados através do programa de Termo de Compromisso de Cessação - TCCs, instrumento que secunda o acordo de leniência e é disponível àqueles que não lograram êxito nesta, através da concessão de benefícios menos atrativos (RUFINO e MENDES, 2015a, p. 427). Percebe-se, aqui, uma segunda corrida, de contornos um tanto diferentes da primeira. 


\subsubsection{As corridas deflagradas após a primeira}

Conforme já explicado, a estrutura de incentivos do jogo da delação muda bruscamente quando a autoridade já dispõe de informações sólidas sobre a prática do ilícito que se busca condenar, sobretudo quando advindas de acordo de leniência, ocasião em que disporá de evidências sobre o funcionamento interno do ilícito, providas por um de seus participantes. Sabedores que a probabilidade de sofrer uma condenação acentuou-se com a delação anterior e que o proveito retirado da prática diminuiu ou cessou com a sua ruptura, os demais participantes do cartel, por exemplo, se conferida a oportunidade, terão todo o interesse em firmar acordos em que se auto incriminam e corroboram os dados fornecidos por outros delatores em troca de algum grau de leniência quanto à punição cada vez mais certa, nos termos descritos na tabela 5 supra.

A autoridade, por sua vez, extrai vantagens de delações em sequência através do fortalecimento da acusação aos membros do cartel que optem pelo silêncio, ou mais importante, que se atrasem nas corridas pela delação deflagradas desde a primeira leniência firmada. A cada delação em um mesmo caso, corrobora-se o que dito anteriormente, amplia-se o conjunto de provas disponíveis por meio de inéditos documentos e informações trazidos em colaboração pelo novo delator e, efetivamente, aumentam-se os custos associados à opção pelo silêncio em toda a cadeia de infratores: o risco de não ser o primeiro é amplificado pela completa desestruturação de um esquema ilícito que venha a ser denunciado por diversos delatores.

Um programa de leniência sensível ao conjunto de incentivos da delação identificado pela teoria dos jogos, deve ser estruturado de tal forma a segregar os diferentes espaços estratégicos de jogadores de acordo com as condições encontradas, diferenciado a situação do infrator que pondera uma delação diante do desconhecimento do esquema ilícito pelo investigador, daquele premido pela circunstância de já ter sua participação conhecida e pelo receio, agora muito real, de que seus parceiros optem por mitigar sua provável responsabilização através de novos acordos que o reincriminem. 
Nesse contexto, acordos em sequência devem partir do pressuposto de que as novas delações são prováveis, mas obviamente continuarão a depender de vantagens auferíveis, se estruturando para oferecer alguns benefícios àqueles que se dispuserem a colaborar mesmo quando já delatados. Naturalmente, os benefícios de ser o segundo a delatar devem ser inferiores aos experimentados pelo primeiro, e assim sucessivamente. De outro modo, a postura de "pagar para ver" se tornaria irresistível, pois estaria anulado o receio de ser o "otário" (item supra) que é o combustível da corrida pela delação. A definição precisa de qual o ponto exato de diferenciação entre os graus de leniência oferecidos a cada um dos delatores em sequência é matéria complexa, mas a validade do princípio é em si evidente.

Tome-se como exemplo o caso do Cade, com a reformulação da sua política de TCCs trazida pela Resolução ${ }^{\circ}$ 05/2013. O Termo de Compromisso de Cessação de Prática (TCC) é acordo firmado entre Cade e administrado, na qual este assume algumas obrigações em troca da suspensão de processo administrativo contra si em curso, disponíveis para todos os tipos de condutas investigadas pelo Cade. A partir do ano de 2007, com a Resolução no 46, de 04 de setembro de 2007, determinou-se que, nos casos em que "houver sido celebrado acordo de leniência pela SDE, o compromisso de cessação deverá necessariamente conter reconhecimento de culpa por parte do compromissário". Com a Resolução n 05/2013, a assunção de culpa pelo acusado que firmava TCC em cartéis passou a ser obrigatória em qualquer caso (RUFINO e MENDES, 2015a, p. 425-426).

Operou-se, normativamente, o acoplamento entre o TCC firmado em investigações em carteis e o Acordo de Leniência, de forma a evitar que a possibilidade de adoção da via negociada TCC pudesse, sem a necessidade de confissão, ser considerada mais atraente que o Acordo de Leniência, que legalmente a demanda (RUFINO e MENDES, 2015a, p. 426).

Enquanto a leniência, quando firmada em casos em que o Cade não dispõe de informações sobre o ilícito relatado, confere imunidade total em relação à multa esperada pela infração, o TCC firmado em casos de cartel obriga o signatário ao pagamento de contribuição pecuniária. O programa de TCCs do Cade, contudo, contém faixas de descontos percentuais na contribuição a ser paga, em coerência com 
o momento da apresentação da proposta. De acordo com as regras, o primeiro investigado a celebrar um TCC com a Superintendência-Geral, em determinado caso, fará jus a um desconto entre $50 \%$ e $30 \%$ do valor da multa esperada, o segundo a um desconto entre $25 \%$ e $40 \%$, e do terceiro em diante até $25 \%$ de desconto. Se o acordo for realizado após a finalização da instrução, ou seja, perante o Tribunal Administrativo de Defesa Econômica, o desconto deverá respeitar o limite de $15 \%$ e não poderá ser superior a um desconto conferido a um investigado que tenha celebrado um TCC na fase de instrução no mesmo processo (RUFINO e MENDES, 2015a, p. 431-432).

Assim, oferece-se um maior grau de calculabilidade ao administrado sobre qual o valor a ser pago caso opte pelo acordo, ao mesmo tempo em que se garante o escalonamento dos benefícios obtidos pelos investigados. Tais faixas de desconto estabelecem o princípio de que os benefícios devem ser proporcionais à disposição de colaborar com a investigação, estimulando a competição entre os infratores pela adoção da solução negociada. O escalonamento de benefícios estabelecidos de acordo com a ordem de chegada tem o potencial de gerar uma maior instabilidade nos vínculos de confiança estabelecidos em condutas colusivas. Adicionalmente, tal modelagem, como dito, tende a deflagrar uma corrida para o uso do instrumento.

Ao mesmo tempo, não oferece a mesma cobertura que um acordo de leniência, que, além de garantir imunidade na multa esperada, proporciona imunidade criminal. O TCC não inclui este benefício, mesmo impondo a confissão. O acordo de leniência, nesse cenário, permanece mais atrativo (RUFINO e MENDES, 2015b).

É interessante observar que, recentemente, o Cade homologou TCCs, com benefícios concedidos em sequência, nos quais as datas de requerimento, que determinam o nível de concessões obtidas pelo infrator, são bastante aproximadas. Com efeito, no Inquérito Administrativo no 08700.003018/2014-91 (CITAÇÃO 200), que apura cartel nos mercados de resinas para revestimentos e para compósitos, foram assinados 3 (três) TCCs pelo Tribunal Administrativo (Requerimentos $\mathrm{n}^{\circ}$ 08700.004496/2014-19, 08700.004627/2014-68 e 08700.005159/2014-49). Nos casos, os descontos relativos às contribuições pecuniárias fixadas incidiram à razão de $30 \%$ (trinta por cento) a $50 \%$ (cinquenta por cento), de forma progressiva, em 
consonância com a ordem cronológica dos requerimentos de acordo formulados pelas partes interessadas.

Após a implementação das modificações trazidas pela Resolução $n^{\circ}$ 05/2013, foram celebrados 43 acordos com reconhecimento de participação nos fatos investigados, contra 22 firmados nos seis anos precedentes. Nos seis anos anteriores à Resolução nº $05 / 2013$ apenas no processo administrativo que investigava o chamado "cartel das mangueiras marítimas" foi verificada a incidência de acordos em sequência. Após a sua implementação, 15 casos já dispõem de acordos sequenciados, com colaboração. Dos 44 TCCs em cartéis firmados após a reformulação da "política de acordos", 22 foram firmados em negociação perante a Superintendência-geral do Cade e 22 foram negociados apenas com o Tribunal Administrativo de Defesa Econômica (RUFINO e MENDES, 2015a, p. 432-435).

O incentivo à corrida pela delação é uma peça central de um programa de delação. Como em uma batalha que se deseja instigar, o fomento de estratégias preemptivas é um vetor de organização a ser trabalhado. A composição de recompensas pela confissão e custos elevados pela adoção da opção pelo silêncio estimula a procura pelo acordo de leniência. A possibilidade de delações em sequência amplia a confiabilidade de uma investigação em curso, reforçando ainda mais os incentivos básico favoráveis à uma busca vigorosa pelo programa de leniência. Contudo, uma vez iniciados os procedimentos tendentes à assinatura de um acordo de leniência, algumas cautelas devem ser adotadas para que a confissão não se transforme na maldição da investigação que deveria favorecer.

\subsection{Documentação}

Uma reportagem na revista The Economist, publicada em agosto de 2011, relata um fato perturbador. Um projeto executado por uma instituição de caridade norte-americana ajudou a inocentar, usando técnica de identificação por DNA, desde 1992, 271 pessoas inocentes que haviam sido erroneamente condenadas. A partir destes dados, uma análise retrospectiva dos processos condenatórios revelou que 
aproximadamente um quarto destas pessoas havia confessado os crimes pelos quais eram acusados (THE ECONOMIST, 2011).

A assunção de culpa, com as pesadas consequências daí decorrentes, por pessoas que, mais que qualquer outra, sabiam da sua inocência, pode parecer contraintuitivo, mas diversos estudos demonstram exatamente isso (GARRET, 2008; GUDJONSSON, 2003; KASSIN, 2009). Um estudo conduzido por Kassin e Perillo (PERILLO e KASSIN, 2010), com testes realizados em laboratório, apresentou resultados surpreendentes.

Os participantes do estudo eram induzidos a acreditar que participavam de um exame sob seu tempo de reação. Para tanto, deveriam digitar em um teclado um texto que era lido em voz alta por outro participante. Antes de iniciar os trabalhos, eram informados que não deveriam pressionar a tecla "ALT", pois o computador usado na experiência tinha um problema, que o faria parar de funcionar se a tecla proibida fosse digitada. A partir de um determinado ponto do experimento, o computador efetivamente deixava de funcionar (pois havia sido programado para isso) e o examinador suspendia bruscamente a leitura do texto, acusando o participante de ter violado as regras que havia aceitado. Um quarto dos participantes confessou pressionar a tecla, mesmo sendo inocentes (PERILLO e KASSIN, 2010).

Os pesquisadores foram além e fizeram um experimento, em uma universidade, no qual os participantes eram induzidos a acreditar que estavam respondendo a um questionário de índole científica, que deveria ser resolvido individualmente. Na sala em que resolviam às questões, estavam acompanhados de outros supostos respondentes, que na verdade participavam da experiência com pleno conhecimento dos seus objetivos. Durante o teste, alguns desses participantes induziam seus colegas a ajudá-los na resposta, em violação às regras da própria universidade. Posteriormente, mesmo aqueles que tinham se recusado a ajudar eram acusados por um examinador, que afirmava que o teste estava sendo gravado e, quando a área técnica disponibilizasse os vídeos, em momento posterior, teria plenas condições de comprovar a acusação, que sabia falsa. Nessa circunstância, em que a prova da sua inocência estaria disponível em algumas horas, ainda assim, metade dos inocentes assinaram a confissão de culpa que era apresentada pelo seu acusador 
(PERILLO e KASSIN, 2010). Questionados sobre as razões de terem adotado esse comportamento, muitos argumentavam que a certeza futura de sua exoneração pela gravação os deixava confortáveis para confessar e, naquele momento, afastarem o desconforto associado à imputação recebida (PERILLO e KASSIN, 2010).

O estudo provém de uma linhagem de outros trabalhos acadêmicos sobre o papel da inocência e da confissão no sistema judicial (GARRET, 2008; GUDJONSSON, 2003) e corrobora algumas evidências anedóticas de casos em que a confissão por um inocente foi feita, retratada e o acusado, mesmo assim, acabou injustamente sendo condenado (KASSIN, 2009, p. 1231-1233; e GARRET, 2010, p. 1054-1056). A literatura científica e casos conhecidos indicam que o ato de confessar é sujeito a nuances significativas, derivadas da condição humana.

\subsubsection{A confissão e suas vulnerabilidades}

A confissão em um programa de leniência, por exemplo, que diz respeito a fatos pretéritos, que podem estar a anos de distância e são de alta complexidade, está, por natureza, vulnerável a incongruências próprias do processo de reconstrução de fatos por pessoas que os testemunharam ou tomaram parte na sua prática. Além disso, desenvolve-se, uma vez que o delator opta pela cooperação, em um ambiente onde este tentará se adequar às normas do programa, que exigem a assunção de sua culpa e apontamento dos seus comparsas.

A natureza do cartel, como infração que se protrai no tempo e envolve uma pluralidade de participantes, requer que a confissão se atenha a um conjunto de fatos complexos, tais como reuniões, troca de informações e adoção de políticas comerciais que se espraiam pelo tempo e, quando da confissão, devem ser relatados em um conjunto harmônico pelos participantes. Uma leniência firmada por uma empresa, por exemplo, resulta na soma das narrativas de vários empregados, frequentemente, inclusive, por executivos não mais vinculados à pessoa jurídica que busca o programa, e, precisamente por isso, como já exposto, demanda tempo de negociação entre autoridade e beneficiários (CADE, 2015a; CADE, 2015b). Confessar, nesse contexto, é fundamentalmente reconstruir fatos passados. 
Um programa de leniência, cuja variável central é a confissão, portanto, não se afasta das incontáveis idiossincrasias impostas ao processo de confissão e deve estar preparado para internalizar tais singularidades e desenvolver formas de canalizá-las adequadamente ao objetivo a que se propõe, que é obter confissões aptas a subsidiar investigações e condenações de indivíduos e empresas que se engajem na prática de ilícitos coordenados.

A reconstrução de fatos passados dá-se, em grande medida, pelo acesso à memória das testemunhas e envolvidos e, desta forma, está sujeito às conhecidas fragilidades inerentes ao ato de rememorar. Qualquer indivíduo que busque reconstituir, com algum nível de detalhe, o que comeu, conversou ou assistiu apenas alguns dias antes pode verificar o quão custosa é uma descrição exata do ocorrido.

Quando se trata de uma leniência, não se busca apenas a declaração singela de participação em um determinado cartel. Ao contrário, o que se requer é uma descrição o mais pormenorizada dos quesitos "quem, "o que", "como" e "onde". As informações prestadas, por sua vez, subsidiarão imputações sérias aos delatados e servirão de guia para a condução das investigações subsequentes, que podem incluir a realização de busca e apreensão, interceptações telefônicas e de dados, ou seja, gestões no sentido de se afastar, temporariamente, direitos constitucionais relevantes dos investigados.

Uma confissão inconsistente ou que narre fatos inverídicos, contraditórios ou contraditáveis, pode tanto induzir uma investigação para um caminho equivocado, dispersando energia escassa e vital dos órgãos investigadores, quanto se constituir como uma prova inútil, que, uma vez afastada, fortalece a posição dos acusados culpados e desmoraliza o esforço investigatório e o próprio instituto da delação. Mais importante, a aceitação de uma confissão fundamentalmente desacertada acarreta o sério risco de movimentar o aparelho estatal repressor contra um inocente.

A conformação estrutural de programas de leniência, como visto, induz o acusado a cooperar plenamente com os investigadores após tomar a decisão pela confissão, pois disso depende a fruição dos benefícios que busca através dessa opção. Embora os incentivos, como também já exposto, estejam voltados à opção pelo 
silêncio, uma vez decidindo-se o infrator pelo caminho da delação, a tendência é que atue no sentido de se adaptar às regras postas para a concessão da leniência.

Desta forma, o ambiente de um programa de leniência é particularmente suscetível ás vulnerabilidades próprias de uma confissão. Assim como nos exemplos de casos em que a assunção de culpa é assumida mesmo em face da inocência existente, quando o acusado ou o objeto do experimento se dobra às necessidades impostas pela situação delicada vivenciada (PERILLO e KASSIN, 2010), mesmo contra seu interesse mais primário, também o beneficiário da leniência poderá deturpar ou criar fatos aptos a justificar a concessão do benefício cobiçado quando busca o acordo.

\subsubsection{A documentação mitiga os problemas da confissão}

Programas de leniência lidam com os problemas associados às imperfeições da reconstrução oriunda da confissão através da tentativa de documentação do relato. A documentação, assim expressa na maior comprovação possível dos fatos narrados por documentos ou outros elementos externos à própria narrativa do delator, é imprescindível para mitigar, na investigação, as inevitáveis imperfeições decorrentes do processo humano de narrativa.

É por meio de extratos de diárias de hotéis ou refeições, como requerido pelo Guia de Leniência do Cade (CADE, 2016b, p. 33-34), que se reforça a existência de uma reunião com concorrentes que o delator afirma serviu para realizar os acertos necessários à criação e continuidade do cartel. São os emails com as trocas de informação de preços, também sugeridos pelo guia, que demonstram a troca de informações entre concorrentes que é a própria materialidade da infração noticiada.

Evidentemente, a leniência se apoia, em grande medida, no relato confessional do delator, que, como demonstrado, inclui uma pluralidade de participantes, pois, em casos de cartéis, praticados em geral por empresas de porte significativo, o plexo de fatos que integram a infração perpassa a atuação de vários agentes. Isso não significa, contudo - e nem poderia, dado os incentivos acima descritos -, que a autoridade se 
apoiará exclusivamente no relato verbal dos interessados na obtenção do tratamento leniente para seus delitos.

Considerados os incentivos e as vulnerabilidades do processo de confissão, uma delação será tão mais consistente e, portanto, confiável, quanto mais ancorada em evidência documental externa ao relato em si, que servirá como elemento a assegurar um certo grau de certeza ao que descrito pelo delator.

A documentação da delação serve ainda a dois propósitos extremamente relevantes: a proteção contra a sobredelação e a subdelação. A compreensão destes dois conceitos passa, em primeiro lugar, pelo reconhecimento de que a autoridade investigadora enfrenta uma assimetria de informação substancial em relação ao delator. É este quem conhece, em detalhes, o ilícito que se dispõe a confessar e, nessa medida, tem um certo controle sobre a narrativa que vai iniciar nas negociações pela leniência.

\subsubsection{O risco de sobredelação e subdelação ${ }^{14}$}

Como dito, uma vez que o potencial delator decide cooperar, ele buscará se adaptar às regras do programa para obter a proteção prometida. Nesse contexto, todos os fatos e pessoas incluídas na narrativa, que digam respeito à conduta do delator, serão cobertos pelo manto da leniência. Ao mesmo tempo, para serem considerados pertinentes a uma confissão, devem implicar os demais partícipes dos fatos ilícitos relatados. Assim, para cada nova acusação lançada, amplia-se a proteção fornecida.

Esta dinâmica própria da delação embute o risco de o delator exacerbar, voluntária ou involuntariamente, os fatos confessados, pois não incorrerá nos custos a eles associados, dada a proteção oferecida pela leniência, na mesma medida ${ }^{15}$ em que os demais acusados. Daí o risco da sobredelação, consiste na superextensão dos fatos

\footnotetext{
14 Ausente uma palavra em português que defina precisamente o fenômeno, optou-se por um neologismo.

${ }^{15}$ Poderá, claro, sofrer os custos associados à delação narrados no item referente ao sigilo. No entanto, a maior parte deles são inerentes ao próprio ato de delatar, independentemente da extensão da delação, e, por outro lado, se o programa de leniência abordá-los adequadamente, como prescrito, serão minimizados.
} 
delatados, seja para ampliar a segurança oferecida pelo acordo, seja para avançar eventuais interesses próprios incompatíveis com os objetivos da investigação. Neste último caso, não se deve esquecer que, uma vez rompida a dinâmica do cartel - e isso é quase certo quando há leniência -, os acusados passam automaticamente da posição de parceiros no ilícito para antagonistas, na investigação e no processo competitivo. É de se reconhecer, portanto, o risco de uma delação se ampliar com o propósito exclusivo de prejudicar os acusados. Um acordo de leniência que incorpore uma sobredelação tem grandes chances de dispersar desnecessariamente a investigação ou de prejudicar acusados inocentes.

De outro lado, a assimetria de informações própria desse tipo de situação leva a autoridade a não conhecer de antemão a abrangência do ilícito delato e mesmo o grau de participação do potencial delator. $\mathrm{O}$ ato de integrar um esquema ilícito, por sua vez, inclui a obtenção de uma série de vantagens, materiais ou não, e a integração de alianças diversas. É possível, nesse cenário, que o delator esconda da autoridade fatos que podem incriminar outros agentes que pretende proteger ou que os permita fruir dos benefícios da atividade criminosa ocultada, subdelatando em troca de proteção. A leniência, nesse caso, legitimaria e serviria de escudo a atividades ilícitas.

Tanto a sobredelação quanto a subdelação podem ser mitigadas através da maior documentação possível dos fatos confessados. Para a sobredelação, a documentação funcionará como freio que impedirá o investigador de estender exageradamente o conjunto de fatos suscetíveis de tratamento leniente e investigação subsequente. Já quanto a subdelação, proporcionará um controle posterior da conduta do delator, se o andamento das investigações demonstrar que este deixou de relatar fatos correlatos à confissão que sejam relevantes à investigação e aos benefícios conquistados.

Vale ressaltar que a exigência de documentação não deve se revestir de caráter estático, no sentido de não se permitir ajustes no conjunto de fatos e documentos trazidos à autoridade. Considerando as dificuldades de se produzir uma narrativa extensa sobre fatos complexos e distantes, é natural que o processo de reconstituição esteja sujeito a ajustes ao longo de tempo e à medida que se aprofunda. Como já exposto, durante o processo de negociação de um acordo de leniência, o potencial 
signatário realiza pesquisas internas para detectar provas do ocorrido, faz entrevistas com seus funcionários, efetua validação pericial de documentos colhidos, etc. É possível que, no percurso, novos fatos e documentos sejam descobertos, a requerer ajustes na delação. De outro lado, o próprio avanço das investigações conduzidas pela autoridade pode indicar novos caminhos a explorar, requerendo uma reavaliação, também pelo delator, dos dados trazidos. Com efeito, o programa de leniência do Cade, por exemplo, admite ajustes na confissão efetuada, com revisão ou inclusão de novos elementos, desde que haja justificativa plausível e seja observada a boa-fé do delator (CADE, 2016b, p. 36 e 50-51).

Mesmo que adotadas todas as cautelas quanto à documentação da narrativa da delação, contudo, é inevitável que parcela substancial do conteúdo da confissão escore-se exclusivamente na reconstituição da memória dos fatos tal qual, em regra, resulta da soma de diversos depoimentos tomados no curso da negociação de um acordo de leniência. O conteúdo ilícito dos fatos relatados indica que as partes tendem a minimizar os traços documentais, dificultando a posterior referência. Desta forma, o esforço de documentação do que delatado frequentemente será insuficiente para afastar, completamente, os riscos associados à construção de uma narrativa baseada na memória coletiva e efetuada em um ambiente onde os incentivos estão voltados ao detalhamento de fatos ilícitos complexos em troca da complacência estatal.

A tarefa da autoridade que se utiliza das informações geradas a partir de uma confissão, portanto, é reconhecer a vulnerabilidade própria do instituto e avaliá-lo com certo ceticismo e tendo em consideração a sua consistência. Além disso, a ênfase à documentação deve ser dada, senão como requisito para aceitação, ao menos como medida da confiabilidade das informações prestadas.

\section{Conclusão}

O presente trabalho voltou-se a examinar a figura do acordo de leniência, principalmente a versão aplicada no direito antitruste brasileiro, e outros esquemas de colaboração entre investigados e investigadores, em uma barganha que envolve concessões mútuas, a qual rotineiramente se cognomina delação premiada. O objetivo 
era avaliar alguns fundamentos básicos desse tipo de arranjo e explicar a sua utilidade em cada caso.

Em primeiro lugar, buscou-se delimitar o quadro que envolve o combate a ilícitos de colarinho branco, tais como o cartel, com as inevitáveis dificuldades enfrentadas pelas autoridades investigadoras. Desta forma, foram destacadas algumas característica deste tipo de ilícito: (i) o caráter difuso do dano, que não deixa "corpo de delito visível" a facilitar a própria identificação da sua prática; (ii) o poderio econômico de seus praticantes, que se utilizam de técnicas de ocultamento do ilícito, inclusive através da criação ou utilização de redes transnacionais, o que torna difícil a comprovação da prática, mesmo quando se tem ciência da sua existência; (iii) a participação de múltiplos agentes, pessoas físicas e jurídicas, na estruturação e prática do ilícito; (iv) a existência de um conjunto de incentivos fortes para que a prática se mantenha e fortaleça com o decurso do tempo; (v) os agudos efeitos deletérios destes ilícitos, a pedir uma repreensão eficiente por parte do aparelho estatal.

Em seguida, foi demonstrado que o ilícito cartel compartilha destas características e que o exame da forma de combate a este ilícito pode ser de grande valia para a identificação de modelos de investigação eficientes. Posteriormente, justificou-se que uma das formas que as autoridades de defesa da concorrência encontraram no combate a cartéis tem sido a utilização da cooperação de alguns de seus praticantes, que, sabedores dos meandros do conluio, poderão conferir as ferramentas necessárias a um processo investigatório que deslinde em uma condenação coerente com o Estado de Direito. Buscou-se demonstrar que a consciência institucional da utilidade deste tipo de arranjo tem levado à sua proliferação, na arena antitruste internacional e, também, na persecução de ilícitos com características semelhantes no direito brasileiro.

No capítulo I, a teoria dos jogos foi apresentada como fornecedora de um instrumental analítico poderoso para a explicação da estrutura de incentivos básicos dos agentes envolvidos neste processo. O chamado dilema do prisioneiro foi apresentado e utilizado como meio de intepretação dos incentivos em um jogo que envolva a confissão em troca de benefícios ofertados pela autoridade investigatória. Uma adaptação do dilema do prisioneiro para a área de combate a cartéis foi 
efetivada, com a descrição dos elementos essenciais do dilema do prisioneiro aplicado a um integrante de um cartel. Chegou-se, então, à conclusão de que a estrutura fundamental de incentivos para a confissão de um cartel é, a princípio, desfavorável à opção pela confissão, considerados os custos suportados pelo agente que confessa e os benefícios ganhos através da opção pelo silêncio versus os custos e benefícios associados à adoção da confissão.

O capítulo II tratou da introdução dos acordos de leniência na esfera antitruste, inclusive com as inevitáveis referências à sua adoção inicial pelo Departamento de Justiça dos Estados Unidos, com as mudanças ocorridas em 1993. A disseminação de programas de leniência em outras jurisdições, seguindo a modelagem norteamericana, a partir dos anos 90, também foi ressaltada. Explicou-se, sucintamente, as características essenciais e o modo de funcionamento dos programas de leniência dos EUA e da Comissão Europeia, além da apresentação, também em linhas gerais, do funcionamento do programa de leniência brasileiro, com descrição da sua previsão normativa, requisitos, benefícios e normas de operacionalização. A partir da análise comparada, observou-se que algumas características são compartilhadas pela maioria dos programas, especialmente regras e práticas tendentes a: (a) conferir previsibilidade ao programa; (b) garantir um certo grau de sigilo às negociações e ao acordo em si, (c) gerar incentivos para uma corrida para a confissão, (d) comprovar documentalmente as informações trazidas na confissão.

No capítulo III, cada uma destas características comuns foi isolada e avaliada de acordo com a modelagem do dilema do prisioneiro, derivada da teoria dos jogos, adaptada aos cartéis, de forma a demonstrar como podem eventualmente se apresentar consistentes ou inconsistentes com estes pressupostos.

No que concerne à previsibilidade, foi explicado como os incentivos contra a confissão devem ser combatidos através do estabelecimento de benefícios claros e automaticamente obtiveis, em caso de aderência da confissão às regras do programa pois: a) a pesagem dos benefícios da adesão versus o silencio só tem sentido se os benefícios forem efetivamente auferidos; b) do mesmo modo, a pesagem dos benefícios da adesão versus o silencio só tem sentido se os benefícios forem conhecidos. Foi referido que esse era um problema do programa de leniência 
americano antes da reforma de 1993, que condicionava a amplitude à discrição do investigador. Observou-se que os benefícios da leniência oferecida pelo Cade são fixos e automaticamente fruíveis, em contradição aos previstos na leniência prevista na lei anticorrupção.

Ressaltou-se a relevância da definição precisa de regras de procedimento para afastar o receio que eventuais delatores podem ter, quando pensam em procurar a autoridade, considerando-se que: a) dificilmente há inibidor maior de se optar por um caminho se este for obscuro; b) é importante que a comunidade especializada (advogados) possa ter a capacidade de explicar o caminho para delatores em potencial e convencê-los a adotar a opção; c) a definição de regras de convivência entre autoridade e investigado facilita que o foco do procedimento seja nas questões espinhosas relacionadas à elucidação da situação. O guia de leniência do Cade foi apresentado como exemplo de documento que atua nesse sentido, ao oferecer um passo a passo acessível sobre o programa de leniência brasileiro. Também foi realçada a importância da prévia identificação e definição do papel de cada interlocutor no processo de negociação da leniência, sendo o memorando de entendimentos entre Cade e MPF apresentado como exemplo que cumpre essa função.

A existência de regras que prevejam uma porta de saída segura para uma tentativa de confissão fracassada foi referida como estímulo à opção pela delação. Explicou-se que a insegurança sobre a adequação do delator às regras do programa é inibidora da decisão de buscar o acordo, devido à sensação de vulnerabilidade de quem se entrega a quem tem a capacidade de punir. Enfatizou-se que a construção de uma relação de confiança entre as partes é instrumental ao objetivo de compartilhamento de informações.

Demonstrou-se que a comunicação efetiva do que a autoridade espera obter do delator para uma maior compreensão do programa e, portanto, da sua aceitação, é essencial, pois a sinalização dos objetivos do programa, por exemplo, através de normas voltadas à conformação de critérios de entrada ajuda o potencial delator a estabelecer sua autoimagem como beneficiário. Defendeu-se, também, a solidificação de práticas e procedimentos que fortaleçam o cumprimento do que pactuado no 
acordo por ambas as partes pactuantes (Estado e Delator), para confiabilidade de longo prazo do programa.

No quesito dedicado ao sigilo, buscou-se evidenciar que a modelagem de um acordo de leniência é fundamentalmente um processo adversarial, entre autoridades e membros do conluio, em que aquela busca quebrar os vínculos de cooperação entre os comparsas na tentativa de penetrar o esquema ilícito. Foi alertado que nível de exposição a que está sujeito um delator recomenda que o processo de confissão, especialmente as tratativas iniciais, deve estar sujeito ao máximo sigilo, posto que tanto a execração pública quanto, mais importante, as interferências de potenciais afetados pela confissão podem ser fatores dissuasórios da utilização da opção oferecida pelo programa de delação. O sigilo também foi invocado como instrumental ao prolongamento das tratativas conducentes à confissão, sendo ferramenta de aumento da alavancagem da autoridade para cumprir com o objetivo de obter delações sólidas e avançar nas investigações através de informações obtidas, que ainda serão desconhecidas dos demais partícipes da atividade criminosa.

Também foi ressaltado que o sigilo deve ser utilizado para permitir que a situação do delator não seja fragilizada, do ponto de vista processual, relativamente aos demais conspiradores, com o propósito de tornar a opção por confessar mais atraente. Foi explicado que a existência de uma delação e a eventual divulgação do nome do beneficiário é consectário lógico da existência de um processo e da punição dos demais infratores e que, desta forma, os custos não mitigados ou eliminados pelo programa de leniência serão suportados pelo delator em algum momento, sendo este, em si, um fator inibidor a delação. Além disso, rememorou-se que a solução do dilema do prisioneiro passa pela racionalidade dos jogadores, que terão a solução confessar como atrativa sobretudo para evitar permanecer em uma situação na qual não se confessa e assume-se todos os custos decorrentes da confissão do seu comparsa e que esta solução só faz sentido se aquele que não confessa efetivamente estiver em uma situação pior que a do delator. Como consequência, asseverou-se que há uma assunção imediata de riscos pelo delator que não é acompanhada ao mesmo tempo e no mesmo grau por quem não delata, decorrente da diferença entre quem confessou e quem é acusado. Buscou-se evidenciar que essa diferença, inerente a um processo deflagrado por uma delação, pode desestabilizar a balança de risco em sentido 
contrário a quem confessa e que uma forma de reequilibrar os incentivos é o uso de normas de sigilo que busquem colocar o delator, ao menos, em posição igual aos delatados na exposição decorrente da tramitação da investigação. A exposição de beneficiários de leniências firmadas em investigação de cartéis a ações de recuperação de danos causados a entes privados foi utilizada como exemplo de risco assumido por delatores, que devem ser de alguma forma abordados no desenho de programas de leniência.

$\mathrm{Na}$ abordagem da existência de regras e práticas tendentes ao estabelecimento de uma corrida pela delação foi explicitado o conceito de preempção e sua posição central como elemento apto a justificar a busca pela confissão, mesmo em um ambiente onde os benefícios hauridos através da opção pelo silêncio são significativos.

Realçou-se, outrossim, o mérito de que os benefícios sejam escalonados de forma a incentivar fortemente que um potencial delator busque ser o primeiro a confessar, posto que tal fato, por si só, pode ser poderoso fator de desestabilização de arranjos conspiratórios. Foi descrito como a estrutura de incentivos para a confissão muda radicalmente após a primeira delação de uma determinada infração, requerendo uma abordagem diferente para novas delatores, que preveja a calibração de incentivos de tal forma que seja fixada uma diferença substancial entre os benefícios obtidos pelo primeiro delator e os subsequentes, de forma a evitar a adoção de estratégias do tipo “esperar para ver”. Defendeu-se, também, que a combinação de diferentes delações fortalece uma investigação e, portanto, torna mais arriscada a opção por não confessar e mesmo permanecer ou se engajar no ilícito.

No tópico destinado a comentar a necessidade de documentação da narrativa existente na confissão, foi discutido como um processo de confissão é vulnerável a interesses contraditórias e muitas vezes contraintuitivos. Foi exposto que uma negociação de uma confissão que se prolonga por meses diz respeito a fatos pretéritos, que podem estar a anos de distância e são de alta complexidade, está, por natureza, vulnerável a incongruências próprias do processo de reconstrução de fatos por pessoas que os testemunharam ou tomaram parte na sua prática, sendo, portanto, suscetível ao caráter eminentemente traiçoeiro da memória humana, que pode induzir, ainda que de 
boa-fé, a reconstrução equivocada de fatos. Foi ressaltado que, em uma leniência, o que se requer não é apenas a declaração singela da participação no cartel, mas uma descrição pormenorizada de "o quê", "quando", "onde" e "quem”, o que torna a tarefa de reconstruir os fatos particularmente delicada.

Alertou-se que essas incongruências podem contaminar uma delação a ponto de torná-la inútil ou até mesmo contraprodutiva, pois uma confissão inconsistente ou que narre fatos inverídicos, contraditórios ou contraditáveis, pode tanto induzir uma investigação para um caminho errado, quanto se constituir como uma prova inútil, que, uma vez afastada, fortalece a posição dos acusados. Defendeu-se, então, que a documentação, assim entendida como a maior comprovação possível dos fatos narrados por documentos ou outros elementos externos à própria narrativa do delator, é imprescindível para mitigar, na investigação, as inevitáveis imperfeições decorrentes do processo humano de narrativa.

Acrescentou-se que um esquema de delação é suscetível a que o delator exagere na inclusão de fatos ou pessoas em sua narrativa, seja para ampliar a segurança oferecida pelo acordo, seja para avançar eventuais interesses próprios incompatíveis com os objetivos da investigação e também é exposto a que o delator esconda da autoridade fatos que podem incriminar outros agentes que pretende proteger ou que os permita fruir dos benefícios da atividade criminosa ocultada. A documentação da narrativa, foi apresentada como remédio para eliminar ou ao menos mitigar os efeitos deste tipo de conduta, através do oferecimento de meios de ancorar a narrativa em uma realidade minimante demonstrável.

Por fim, ponderou-se que, de todo modo, um esquema de delação escora-se, fundamentalmente, na reconstrução pela memória dos diversos envolvidos nos fatos relatados e está, por definição, sujeito aos riscos acima delineados, sendo papel da autoridade utilizar as informações fornecidas com moderação e emprestar sua confiança proporcionalmente à ancoragem documental da narrativa apresentada. 


\section{Bibliografia}

ANDERSON, Patrick; BOLEMA, Theodore; GECKIL, Ilhan. Damages in antitrust cases. AEG Working Paper 2007-2. East Lansing, Chicago: Anderson Economic Group, 2007. Disponível em:

<http://www.andersoneconomicgroup.com/Portals/0/upload/Doc2066.pdf. 2007>. Acesso em: 01 set. 2016.

ANDRADE, Luiza Andrade. Programas de leniência e a responsabilidade civil concorrencial: o conflito entre a preservação dos interesses da leniência e o direito à indenização. Revista de Defesa da Concorrência, v. 3, n. 2. Novembro/2015, p. 114132.

BARNETT, Belinda A.; HAMMOND, Scott D. Frequently asked questions regarding the antitrust division's leniency program and model leniency letters. Department of Justice, Novembro/2008. Disponível em:

<https://www.justice.gov/atr/file/810001/download>. Acesso em: 01 set. 2016.

BINMORE, Ken. Game theory: a very short introduction. Oxford: Oxford University Press, 2007, p. 184.

BOLDT, Raphael. Delação premiada: o dilema ético. In: Jus Navigandi, Teresina, ano 9, n. 783, 25 ago. 2005. Disponível em:

<http://jus2.uol.com.br/doutrina/texto.asp?id=7196>. Acesso em: 18 dez. 2014.

BOS, Iwan; WANDSCHNEIDER, Frederik. Cartel ringleaders and the corporate leniency program. optimal corporate leniency program. CCP Working Paper 11-13. Disponível em: <http://ssrn.com/abstract=1910000>. Acesso em: 18 dez. 2014.

BRAITHWAITE, John. White collar crime. Annual Review of Sociology, v. 11, Annual Reviews, 1985. Disponível em: 〈http://www.jstor.org/stable/2083283>. Acesso em: 31 ago. 2016.

BRANDENBURGUER, Adam. Cooperative game theory: characteristic functions, allocations, marginal contribution. 01 abr. 2007. Disponível em:

$<$ http://www.uib.cat/depart/deeweb/pdi/hdeelbm0/arxius_decisions_and_games/coope rative_game_theory-brandenburger.pdf $>$. Acesso em: 01 set. 2016.

BURHART, Jacques; HENRY, David. Leniency regimes. 5. ed. Londres: Thomson Reuters, 2015, p. 418.

CALLIARI, Marcelo Procópio. A aplicabilidade da teoria dos jogos ao direito internacional: um estudo exploratório. São Paulo: Universidade de São Paulo, 2003, p. 136.

CHANG, Myong-Hun; HARRIGTON JR., Joseph E. The impact of a corporate leniency program on antitrust enforcement and cartelization. 20 fev. 2009. Working papers, The Johns Hopkins University, Department of Economics, n. 548. Disponível 
em:

$<$ https://www.csuohio.edu/class/sites/csuohio.edu.class/files/media/economics/docum ents/3.pdf>. Acesso em: 01 set. 2016.

CHAPPATTE, Phillip; WALTER, Paul. In: VARNEY, Christine A. The cartels and leniency review. 2. ed. Londres: Law Business Research, 2014, p. 100-115.

CONSELHO ADMINISTRATIVO DE DEFESA ECONÔMICA. Secretaria de Direito Econômico. Combate a cartéis e programa de leniência. Coleção CADE/SDE, n. 1. Brasília: Imprensa Oficial, 2009.

Processo administrativo n. 08012.002127/2002-14. Plenário. Relator: Luiz Carlos Tadeu Delorme Prado, 2005.

Processo administrativo n. 08012.007356/2010-27. Superintendência-Geral do CADE, 2013a.

Processo administrativo n. 08012.001003/2000-41. Plenário. Relator: Ana de Oliveira Frazão, 2013b.

. Processo administrativo n. 08012.001794/2004-33. Plenário. Relator: Ricardo Machado Ruiz, 2014a.

. Processo administrativo n. 08012.011142/2006-79. Plenário. Relator: Alessandro Octaviani Luis, 2014b.

. Processo administrativo n. 08012.000773/2011-20. Plenário. Relator: João Paulo Rezende, 2016c.

Processo administrativo n. 08700.002086/2015-14. Superintendência-Geral do CADE, 2016e.

Histórico da conduta do Acordo de Leniência firmado entre CADE e Construções e Comércio Camargo Correa S.A.. 2015a. Disponível em:

$<$ http://www.cade.gov.br/noticias/cade-celebra-acordo-de-leniencia-em-investigacaode-cartel-em-licitacao-da-usina-angra-3/historico_da_conduta_publico.pdf $>$. Acesso em: 01 set. 2016.

. Histórico da conduta do Acordo de Leniência firmado entre CADE e Setal/SOG Óleo e Gás. 2015b. Disponível em:

<http://www.cade.gov.br/noticias/cade-celebra-acordo-de-leniencia-no-ambito-da201 coperacao-lava-jato201d/hc-versao_publica.pdf>. Acesso em: 01 set. 2016.

Programa de leniência. 2016a. Disponível em:

<http://www.cade.gov.br/assuntos/programa-de-leniencia>. Acesso em: 01 set. 2016.

. Guia do Programa de Leniência Antitruste do Cade. 2016b. Disponível

em: <http://www.cade.gov.br/acesso-a-informacao/publicacoes-

institucionais/guias_do_Cade/guia_programa-de-leniencia-do-cade-final.pdf $>$. Acesso em: 01 set. 2016. 
Memorando de entendimento n. 1/2016. 2016d. Disponível em:

$<\mathrm{http} / / / \mathrm{www}$.cade.gov.br/assuntos/programa-de-leniencia/memorando-deentendimentos-sg-e-mpfsp_tcc-e-acordos-de-colaboracao_15-03-2016.pdf>. Acesso em: 01 set. 2016.

CONTROLADORIA GERAL DA UNIÃO (CGU). Ministério da Transparência celebra acordo de leniência com a SBM Offs. 2016. Disponível em:

$<$ http://www.cgu.gov.br/noticias/2016/07/ministerio-da-transparencia-celebra-acordode-leniencia-com-a-sbm-offshore>. Acesso em: 01 set. de 2016.

COMISSÃO EUROPEIA. Comunicação da comissão relativa à imunidade em matéria de coimas e à redução do seu montante nos processos relativos a cartéis. 2006. Disponível em: <http://eur-lex.europa.eu/legalcontent/PT/TXT/PDF/?uri=CELEX:52006XC1208(04)\&from=EN>. Acesso em: 01 set. 2016.

Tratado sobre o funcionamento da União Europeia. Artigos 101-109. 2010. Disponível em: <http://eur-lex.europa.eu/legalcontent/PT/TXT/PDF/?uri=CELEX:12012E/TXT\&from=PT>. Acesso em: 01 set. 2016.

Delivering oral statements at DG Competition. 2013. Disponível em: <http://ec.europa.eu/competition/cartels/leniency/oral_statements_procedure_en.pdf >. Acesso em: 01 set. 2016.

Diretiva 2014/104/EU do Parlamento Europeu e do Conselho. 2016.

Disponível em: <http://eur-lex.europa.eu/legalcontent/PT/TXT/PDF/?uri=CELEX:32014L0104\&from=PT>. Acesso em: 01 set. 2016.

FEHR, Ernst; FISCHBACHER, Urs. The nature of human altruism. Nature, Zurique, v. 425, p. 785-791, 23 out. 2003. Disponível em:

<http://www.iwp.jku.at/born/mpwfst/04/nature02043_f_born.pdf >. Acesso em: 18 dez. 2014.

GABAN, Eduardo M.; DOMINGUES, Juliana O. Direito antitruste. 3. ed. São Paulo: Saraiva, 2012, p. 456.

GARRETT, Brandon L. Judging innocence. Columbia Law Review, Janeiro/2008. Disponível em: <http://ssrn.com/abstract=999984>. Acesso em: 31 ago. 2016.

. The substance of false confessions (April 15, 2010). Stanford Law Review, v. 62, n. 4, 2010; Virginia Public Law and Legal Theory Research Paper, n. 2010-11. Disponível em: <http://ssrn.com/abstract=1280254>. Acesso em: 31 ago. 2016.

GÄRTNER, Dennis. Corporate leniency in a dynamic world: the preemptive push of an uncertain future. fev. 2014. Disponível em: <http://ssrn.com/abstract=2340973>. Acesso em: 01 set. 2016. 
GILBERT, Michael J.; HUEY-BURNS, Paul. Lessons for business in an era of global anti-corruption efforts. New York Law Journal, v. 241, n. 24, 2009, p. 2.

GOVERNO DOS ESTADOS UNIDOS DA AMÉRICA. The Sherman antitrust act. 1890. Disponível em: <http://www.linfo.org/sherman_txt.html >. Acesso em: 01 set. 2016.

GREGHI, Fabiana. A delação premiada no combate ao crime organizado. Revista de Direito Público. v. 2, n. 3, Londrina, Set/Dez. 2007, p. 3-24.

GRIFFIN, James M. The modern leniency program after ten years - A summary overview of the Antitrust Division's Criminal Enforcement Program. Apresentado no encontro anual da seção de antitruste da American Bar Association. San Francisco, California, 12 ago. 2003.

GUDJONSSON, Gisli $\mathrm{H}$. The psychology of interrogations and confessions: a handbook. Londres: Wiley, 2003, p. 705.

HAMMOND, Scott D. Fighting cartels - Why and how? Lessons common to detecting and deterring cartel activity. Apresentado na ocasião da $3^{\text {a }}$ Conferência Nórdica de Política Concorrencial. Suécia: Estocolmo, 2000.

Cornerstones of an effective leniency program. Apresentado na ocasião do "Chilean Competition Day". Chile: Santiago, 2009.

HARRINGTON, Joseph E. Optimal corporate leniency program. Working papers, The Johns Hopkins University, Department of Economics, n. 527, 2005. Disponível em: <http://hdl.handle.net/10419/71977>. Acesso em: 18 dez. 2014.

Corporate leniency programs when firms have private information: the push of prosecution and the pull of pre-emption. The Journal of Industrial Economics, v. LXI, mar. 2013, p. 27. Disponível em:

<http://assets.wharton.upenn.edu/ harrij/pdf/jie13.pdf>. Acesso em: 01 set. 2016.

HARGREAVES HEAP, Shaun P.; VAROUFAKIS, Yanis. Game theory: a critical introduction. Londres: Routledge, 1995, p. 259.

HAYWOOD, O. G. Military theory and game theory. Journal of Operations Research Society of America, Nov./1954, p. 365-385.

HEYER, Ken. A world of uncertainty: economics and the globalization of antitrust. Antitrust Law Journal, v. 72, n. 2, 2005, p. 375-422.

HOVENKAMP, Herbert. Federal antitrust policy - the law of competition and its practice. 4. ed. Hornbook Series. St. Paul, MN: Thomson Reuters, 2011, p. 906.

INTERNATIONAL CHAMBER OF COMMERCE (ICC). ICC Leniency Manual. 2016. Disponível em: <http://www.iccwbo.org/advocacy-codes-and-rules/areas-ofwork/competition/cartels-and-leniency>. Acesso em: 01 set. 2016. 
JEANROND, Jakon. Information bargaining in leniency programs. Lund: Lund University, 2007, p. 27. Disponível em:

<http://lup.lub.lu.se/luur/download?func=downloadFile\&recordOId=1334890\&fileOI $\mathrm{d}=1646310>$. Acesso em: 01 set. 2016.

JESUS, Damásio E. de. Estágio atual da "delação premiada" no direito penal brasileiro. In: Jus Navigandi, Teresina, ano 10, n. 854, 4 nov. 2005. Disponível em: <http://jus.com.br/artigos/7551>. Acesso em: 18 dez. 2014.

KAPLOW, Louis; SHAVELL, Steven. Decision analysis, game theory and information. Nova Iorque: Foundation Press, 2004, p. 82.

KASSIN, Saul. False confessions. Albany Law Review, v. 73, n. 4, 2009-2010, p. 1227-1234. Disponível em:

$<$ http://heinonline.org/HOL/Page?handle=hein.journals/albany73\&div=56\&start_page $=1227 \&$ collection $=$ journals $\&$ set_as_cursor $=1 \&$ men_tab=srchresults $>$. Acesso em: 01 set. 2016.

KLOUB, Jindrich. Leniency as the most effective tool in combating cartel. Apresentado na ocasião do $7^{\circ}$ Forum Latino Americano de Concorrência. Chile: Santiago, set. 2009.

KOBAYASHI, Bruce H. Antitrust, agency and amnesty: an economic analysis of the criminal enforcement of the antitrust laws against corporations. George Washington Law Review, v. 69, n. 5-6, October-December, 2001, p. 715-744. Disponível em: $<$ http://papers.ssrn.com/sol3/papers.cfm?abstract_id=305260>. Acesso em: 01 set. 2016.

LESLIE, Cristopher R. Trust, distrust and antitrust. Texas Law Review, v. 82, n. 3, 2004, p. 517-680.

Antitrust amnesty, game theory, and cartel stability. Journal of Corporation Law, v. 31, 2006, p. 453-488. Disponível em: 〈http://ssrn.com/abstract=924376〉. Acesso em: 18 dez. 2014.

LEVENSEIN, Margareth C.; SUSLOW, Valerie Y. Breaking up is hard to do: determinants of cartel duration. Ross School of Business Paper, n. 1150. Setembro de 2010. p. 51. Disponível em: <http://ssrn.com/abstract=1676968>. Acesso em: 01 set. 2016.

LIU, Nanjiang. Historical uses of game theory in battles during the World War II. 11 dez. 2015. Disponível em:

<http://myslu.stlawu.edu/ nkomarov/450/AmberPaper.pdf>. Acesso em: 01 set. 2016.

LUZ, Reginaldo Diogo; SPAGNOLO, Giancarlo. Leniency, collusion, corruption, and whistleblowing. 18 abr. 2016. Disponível em:

<http://ssrn.com/abstract=2773671>. Acesso em: 01 set. 2016.

LYNCH, William S.; PHILLIPS, James W. Organized crime - violence and corruption. Journal of Public Law. Emory Law School. 1974, p. 59-70. Disponível 
em:

$<$ http://heinonline.org/HOL/Page?handle=hein.journals/emlj20\&div=10\&start_page= 59\&collection=journals\&set_as_cursor=0\&men_tab=srchresults $>$. Acesso em: 01 set. 2016.

MARTINEZ, Ana P. Repressão a cartéis - interface entre direito administrativo e direito penal. São Paulo: Singular, 2013, p. 364.

McCARTY, Nolan; MEIROWITZ, Adam. Political game theory: an introduction. Cambridge: Cambridge University Press, 2007, p. 415.

MELLO, Magno Antonio Correia de. Programas de leniência em países membros e parceiros da Organização para a Cooperação e Desenvolvimento Econômico. Câmara dos Deputados, Consultoria Legislativa. nov./2015. Disponível em: <http://bd.camara.gov.br/bd/handle/bdcamara/26442\#>. Acesso em: 01 set. 2016.

MENDES, Francisco Schertel Ferreira. $O$ controle de condutas no direito concorrencial brasileiro: características e especificidades. Brasília: Universidade de Brasília, 2012, p. 109.

MENDES, Gilmar Ferreira; COELHO, Inocêncio Mártires; BRANCO, Paulo Gustavo Gonet. Curso de direito constitucional. 2. ed. ver. e atual. São Paulo: Saraiva, 2008, p. 546.

MOTCHENKOVA, Evgenia. Effects of leniency programs on cartel stability. Center Discussion Paper, n. 2004-98. Setembro de 2004. Disponível em: <http://ssrn.com/abstract=617224>. Acesso em: 01 set. 2016.

MOTTA, Massimo; POLO, Michele. Leniency programs and cartel prosecution. International Journal of Industrial Organization, v. 21, 2003, p. 347-379.

NASAR, Sylvia. A beautiful mind. Nova Iorque: Simon e Schuster, 2011, p. 461.

PASTRE, Diogo Willian Likes. O instituto da delação premiada no direito processual penal brasileiro. Revista IOB de Direito Penal e Processual Penal. Ano IX, n. 53, 2009.

PEREIRA NETO, Caio Mário da Silva; CASAGRANDE, Paulo Leonardo. Direito concorrencial: doutrina, jurisprudência e legislação. São Paulo: Saraiva, 2016, p. 512.

PERILLO, Jennifer T.; KASSIN, Saul M. Inside interrogation: the lie, the bluff, and false confessions. American Psychology-Law Society/Division 41 of the American Psychological Association 2010. Disponível em:

$<$ http://web.williams.edu/Psychology/Faculty/Kassin/files/Perillo\%20\&\%20Kassin\%2 0(in\%20press)\%20-\%20LHB\%20bluff\%20studies>. Acesso em: 01 set. 2016.

RUFINO, Victor Santos. Análise da conformação normativa do programa de leniência brasileiro à luz da teoria dos jogos. Revista de Direito Setorial e Regulatório, v. 1, n. 1, maio de 2015. Brasília: Universidade de Brasília, 2015, p. 47-65. 
RUFINO, Victor Santos; MENDES, Francisco Schertel Ferreira. Evolução das normas sobre TCCs em cartéis após a Lei 12.529/2011. In: CARVALHO, Vinícius Marques. A lei 12.529/2011 e a nova política de defesa da concorrência. São Paulo: Singular, 2015, p. 425-435. 2015a.

. Colaboração no combate a cartéis. Folha de São Paulo, 14 out. 2015.

Disponível em: <http://www1.folha.uol.com.br/opiniao/2015/10/1693592-

colaboracao-no-combate-a-carteis.shtml>. Acesso em: 01 set. 2016.

SALOMI, Maíra Beauchamp. O acordo de leniência e seus reflexos penais. São Paulo: Universidade de São Paulo, 2012, p. 293.

SANTOS, Flávia Chiquito dos. Aplicação de penas na repressão a cartéis: uma análise da jurisprudência do CADE. Rio de Janeiro: Lumen Juris, 2016, p. 303.

SCHINKEL, Maarten Pieter. Forensic economics in competition law enforcement. Journal of Competition Law and Economics, v. 4, n. 1, 2008, p. 6.

SCHUARTZ, Luis Fernando. Haverá lugar digno para o "jurídico” na teoria e prática do direito antitruste. In: Revista do IBRAC, v. 3, n. 2, 2006, p. 153-182.

SILVA E SOUZA, Nayara. Mecanismos de proteção ao programa de leniência brasileiro: um estudo sobre a confidencialidade dos documentos e a responsabilidade civil do signatário à luz do direito europeu. 2014, p. 40-42. Disponível em: $<$ http://seae.fazenda.gov.br/premio-seae/edicoes-anteriores/edicao-2014/ix-premioseae-2014/tema1-MH-Nayara.pdf>. Acesso em: 01 set. 2016.

SPAGNOLO, Giancarlo. Divide et impera: optimal leniency programs. Suécia: Estocolmo, 12 jan. 2005. Stockholm School of Economics Consio Spa, and C.E.P.R. Disponível em: <http://papers.ssrn.com/sol3/papers.cfm?abstract_id=716143>. Acesso em: 18 dez. 2014.

. Leniency and whistleblowers in antitrust. Itália: Roma, 23 jun. 2005. Preparado para a Conferência LEAR "Advances in the Economics of Competition Law”. Disponível em: <http://ssrn.com/abstract=936400>. Acesso em: 18 dez. 2014.

SPAGNOLO, Giancarlo; BUCCIROSSI, Paolo. Leniency policies and illegal transactions. Dez./2005. CEPR Discussion Paper, n. 5442. Disponível em: <http://ssrn.com/abstract=897921>. Acesso em: 01 set. 2016.

SPRATLING, Gary R. The corporate leniency policy: answers to recurring questions. Estados Unidos: Washington, D.C., 01 abr. 1998. Apresentado no encontro anual da primavera sobre antitruste da American Bar Association.

Making companies an offer they shoudn't refuse. Estados Unidos:

Washington, D.C., 16 fev. 1999. Apresentado no 35º simpósio sobre antitruste da American Bar Association.

STEPHAN, Andreas; NIKPAY, Ali. Leniency theory and complex realities. University of East Anglia, Centre for Competition Policy. Working Paper, n. 14-8. Dezembro de 2014, p. 23. Disponível em: 
$<$ http://papers.ssrn.com/sol3/papers.cfm?abstract_id=2537470>. Acesso em: 01 set. 2016.

THE ECONOMIST. Silence is golden. 13 Ago. 2011. Disponível em:

<http://www.economist.com/node/21525840>. Acesso em: 01 set. 2016.

TRIBUNAL DE CONTAS DA UNIÃO (TCU). Acórdão n. 225/2015 - TCU Plenário. 2016. Disponível em:

<http://portal3.tcu.gov.br/portal/page/portal/TCU/imprensa/noticias/noticias_arquivos /002.6122015-1\%20(Acordos\%20de\%20leniencia).pdf >. Acesso em: 01 set. 2016.

\section{U.S. DEPARTMENT OF JUSTICE, ANTITRUST DIVISION (DoJ). Leniency} program. 2016. Disponível em: <https://www.justice.gov/atr/file/810001/download>. Acesso em: 01 set. 2016.

VARNEY, Christine A. United States. The cartels and leniency review. 2. ed. Londres: Law Business Research, 2014, p. 434.

VON NEUMANN, Jon; MORGENSTERN, Oskar. The theory of games and economic behavior. Princeton: Princeton University Press, 1990. 